$$
\begin{gathered}
\text { UNITED STATES } \\
\text { DEPARTMENT OF THE INTERIOR } \\
\text { GEOLOGICAL SURVEY } \\
\text { Water Resources Division }
\end{gathered}
$$

\title{
GEOLOGY AND GROUND WATER IN \\ INDIAN WELLS VALLEY, CALIFORNIA
}

By

Fred Kunkel and G. H. Chase

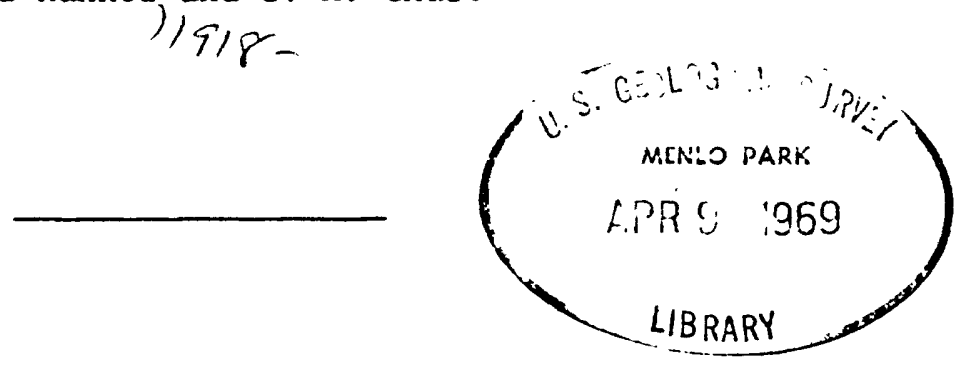

Prepared in cooperation with the

Naval Weapons Center

Chịna Lake, California

OPEN-FILE REPORT

69.329

Menlo Park, California

January 23, 1969 


\section{CONTENTS}

Abstract-

Introduction-1.-

Purpose and scope-1.

Location of the area-1

Previous work-1.2.

Acknow ledgments-1

Jeography-1.0

Topographic features and drainage-

Climate-1.2.

Early development and culture-1.

Water use-10. Seology

Geologic formations and their water-bearing properties-..........

Basement complex-1..

Continental deposits-1

Black Mountain Basalt-1.

Older alluvium-

01der lacustrine deposits

Unnamed volcanic rocks-1..

Fan deposits-1

Younger alluvium-

Younger lacustrine deposits-1

Playa deposits-

Windblown sand and interdune playa deposits

Windblown sand-1...

Geologic structure-

Faults-10

Relation of dikes to structure

Folding and other structures-1.

Geologic history-1. 35

Regional history-1.. 35

Ground-water basin history-1.. 36

Ground water-1. 38

Occurrence of ground water-1. 38

Main water body- 39

Shallow water body-1.. 40

Minor water bodies-1.. 41

Source and movement of ground water- 42 
Ground water--Continued

Fluctuations of water level.

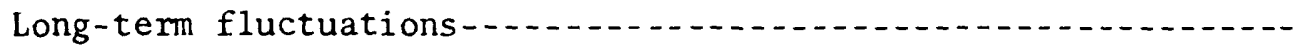

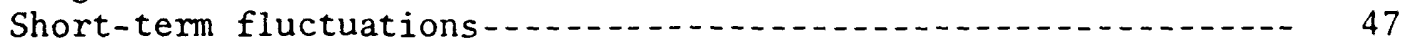

Chemical quality of ground water-... 49

Requirements for domestic water..... 49

Requirements for irrigation water-...... 50

Chemical quality of the main water body-..... 51

Well yields.... 54

Transmissibility of the alluvium-..... 58

Pumping tests-... 59

Underflow at midvalley-1......... 61

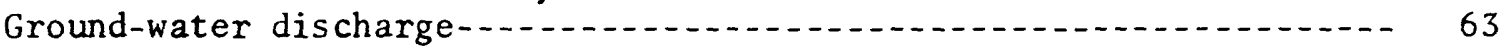

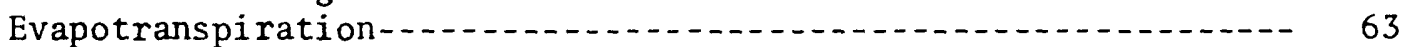

Outflow to Salt Wells Valley-....... 70

Pumpage-1............ 71

Total discharge-1.2. 72

Ground-water recharge-1... 72

Perennial yield......... 73

Disposal of pumped water.... 75

Ground-water storage capacity-..... 76

Storage units and depth zones-1... 77

Specific-yield values-_.......... 79

Estimated ground-water storage capacity-....... 81

Relation of storage to perennial yield

References cited-_. 82 


\section{ILLUSTRATIONS}

Figure 1. Index map of the Indian Wells Valley area-...... Page

2. Geologic map of Indian Wells Valley, California-.....-. In pocket

3. Geologic sections $A-A^{\prime}, B-B^{\prime}, E-E^{\prime}$, and $F-E^{\prime}$,

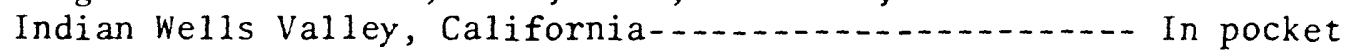

4. Geologic sections $C-C^{\prime}, D-D^{\prime}$, and $G-G^{\prime}$, Indian Wells Valley, California....................... In pocket

5. Maps of Indian Wells Valley, California, showing water-level contours on the main water body.......... In pocket

6. Map of Indian Wells Valley, California, showing water-level contours on the shallow water body-......- In pocket

7. Hydrographs of 10 wells

8. Hydrographs of seven wells

9. Hydrograph of well 26/39-25D1-24

10. Graph of water-level change in two wells compared to change in barometric pressure-1 48

11. Water-analysis diagram-2.. 52

12. Graph showing relation of evapotranspiration to depth of ground water in Indian Wells Valley, California-_... 67

13. Map of the playa area showing ground-water discharge units in the autumn of 1953 68

14. Map showing ground-water storage units-_... 78 
Table 1. Annual rainfall, in inches, at representative stations in and near Indian Wells Valley..... 10

2. Temperature summary, in ${ }^{\circ} \mathrm{F}$, for the 6-year period 1946-51

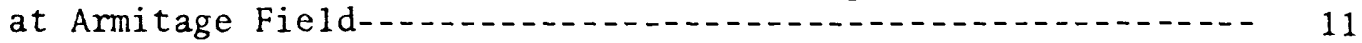

3. Mean hourly wind velocities at Armitage Field for the 6-year period 1946-51-... 11

4. Hardness classification, in parts per million, for domestic water-... 49

5. Pumping rate, drawdown, and specific capacity of wells in Indian Wells Valley-........ 56

6. Transmissibility of the alluvium in Indian Wells Valley determined from pumping tests-..... 60

7. Range in water-level fluctuations beneath the moist lands in and around China Lake, 1912-53 65

8. Consumptive-use coefficients for a dense saltgrass growth in Indian Wells Valley-... 66

9. Classification of moist lands in and around China Lake, and estimated evapotranspiration for 1912 and 1953-.....- 69

10. Estimated pumpage, in acre-feet, for calendar years 1942-67--.- 71

11. Specific-yield values assigned to materials comprising

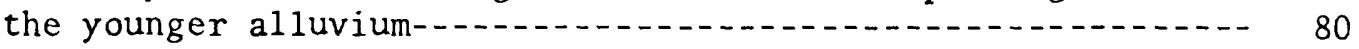

12. Estimated ground-water storage capacity of Indian Wells Valley- 80 
GEOLOGY AND GROUND WATER IN INDIAN WELLS VALLEY, CALIFORNIA

By Fred Kunkel and G. H. Chase

ABSTRACT

1. Geology and water-bearing deposits.--Indian Wells Valley is virtually a closed basin bordered by consolidated generally non-water-bearing rocks. This basin is filled by unconsolidated deposits of clay, sand, and gravel derived from the mountains and bordering highlands. The principal waterbearing deposits are the younger and older alluviums; a main water body occurs in these deposits, principally beneath the surface extent of the younger alluvium.

2. Quality of water.--The quality of water in the main water body contained in the younger alluvium is satisfactory for most domestic and agricultural uses. Locally, in the area southeast and east of Ridgecrest, some water-bearing zones have chloride concentrations greater than $500 \mathrm{ppm}$ (parts per million) and a dissolved-solids content greater than 1,500 ppm. Water of this concentration is unsatisfactory for most uses. Continued heavy pumping of ground water by wells in the vicinity of Ridgecrest might induce a migration of poorquality water, causing a deterioration of water quality in areas where the quality now is satisfactory.

Water in and around the moist lands bordering China Lake is high in chloride and dissolved solids and is unsatisfactory for domestic uses. There are no producing wells in this area, but an increase of pumping at Intermediate and vicinity might lower water levels sufficiently to induce a migration of poor-quality water from the area of China Lake toward the area where the quality now is satisfactory. This was not a critical problem in 1953, but it is desirable to keep a periodic record of water level and water quality in key wells in order to anticipate and to take preventive action should such a migration of poor-quality water occur.

The Inyokern well field is sufficiently distant and far enough up gradient from poor-quality water that no quality problem exists in this area. 
3. Ground-water discharge.--In Indian Wells Valley ground-water discharge occurs naturally by evapotranspiration and underflow into Salt Wells Valley and artificially by pumping from wells. Evapotranspiration is estimated as having been approximately 11,000 acre-feet in 1912 and 8,000 acre-feet in 1953 . This decrease of 3,000 acre-feet presumably was caused by a decline of water levels in the area of evapotranspiration which has decreased the rate of evapotranspiration. The decrease in the rate may be due in part to the effects of a period of abnormally dry years since 1947, but the decline probably is also due to greatly increased ground-water pumping since 1945. The decrease in rate of evapotranspiration caused by ground-water pumping represents natural ground-water discharge or waste that has been salvaged for beneficial use.

Underflow from Indian Wells Valley into Salt Wells Valley occurs through a narrow channel backfilled with windblown sand in sec. 7, T. 26 S., R. 41 E. This channel, the most recent outlet of China Lake, no longer carries surface flow, but the results of test drilling in this channel indicate that an estimated maximum of 20 acre-feet per year of saline ground water may discharge into Salt Wells Valley through this channel.

Ground-water pumpage in Indian Wells Valley prior to 1943 is estimated to have averaged less than 2,000 acre-feet per year. Since 1944 ground-water pumpage has increased each year. Pumpage in 1951, 1952, and 1953 is estimated as $6,500,7,200$, and 8,200 acre-feet.

The estimated total discharge is the sum of the evapotranspiration, ground-water outflow, and pumpage, or about 16,000 acre-feet in 1953.

4. Transmissibility of the water-bearing deposits.--Transmissibility of the water-bearing deposits in Indian Wells Valley, an essential factor in the estimate of perennial yield, was determined from a series of pumping tests run at selected wells in the valley. These tests indicated that the transmissibility of the upper 400 feet of saturated water-bearing deposits in the central part of Indian Wells Valley is about 200,000 gallons per day per foot.

This estimate of transmissibility, utilized in conjunction with the crosssectional area and the hydraulic gradient of 1921, suggests an underflow at midvalley under natural conditions of about 15,000 acre-feet a year. The underflow is a measure of the recharge and discharge. The quantity of groundwater discharge estimated as the sum of evapotranspiration and ground-water outflow, or about 11,000 acre-feet per year under natural conditions, is about 4,000 acre-feet less than the estimate based on transmissibility, crosssectional area, and hydraulic gradient.

5. Perennial yield.--Perennial yield of a ground-water basin is the rate at which ground water can be withdrawn year after year without depleting groundwater storage to such an extent that withdrawal at this rate is no longer feasible because of increased pumping costs or deterioration of quality. The estimated perennial yield of Indian Wells Valley, based on estimates of evapotranspiration and underflow at midvalley together with other ground-water data, is approximately 12,000 acre-feet per year--about 4,000 acre-feet more than the estimated pumpage in 1953 , but about 4,000 acre-feet less than the estimated total discharge. 
6. Ground-water storage capacity.--Ground-water storage capacity of a basin is a reserve that can be utilized during development of that basin and during periods when perennial yield is exceeded. In Indian Wells Valley this reserve, relative to present pumpage, is large. For a zone from the surface of the 1954 water table to 100 feet below, the estimated ground-water storage capacity is about 720,000 acre-feet. The most effective use of the storage capacity and perennial yield would require a more widespread distribution of pumpage than now exists in the western part of the valley.

7. Development of new well fields.--The most effective development of ground water in Indian Wells Valley would be accomplished by a series of wells evenly spaced west of a line extending northwestward from Intermediate to Sandquist Spa and northward from Sandquist Spa to the Inyo County line. Wells in this area would intercept a maximum amount of ground-water recharge to the valley, yet, as long as pumpage was less than the perennial yield, would not cause chemically unsuitable water from the area in and around China Lake to migrate into areas of now potable water.

\section{INTRODUCTION}

\section{Purpose and Scope}

The U.S. Geological Survey in May 1952 began the ground-water investigation of Indian Wells Valley in cooperation with the Naval Weapons Center, China Lake, Calif., for the purpose of determining the available perennial water supply or perennial yield $d^{l}$ of Indian Wells Valley.

In this investigation an attempt has been made to assemble all existing hydrologic and geologic data pertinent to the perennial ground-water supply of Indian Wells Valley. Accordingly, all existing wells in the valley have been field canvassed, and, where possible, measurements of water level have been made and water samples for chemical analyses have been collected. In addition, all the hydrologic data contained in reports prepared as parts of earlier hydrologic investigations in Indian Wells Valley have been assembled, and have been correlated with data obtained during the current investigation; all these records have been published by the California Department of Water Resources (Moyle, 1963).

To estimate the transmissibility of the water-bearing deposits, a necessary factor in the estimate of perennial yield, pumping tests were run at six different well fields. To appraise the ground-water discharge estimates were made of total pumpage and of evapotranspiration from the central playa area of the valley. Insofar as the data allowed ground-water inflow into Indian Wells Valley was also estimated.

\footnotetext{
'The term "perennial yield" is here used to designate the annual rate at which water can be withdrawn from the ground-water reservoir without depleting the supply or impairing the chemical quality to such an extent that withdrawal at this rate is no longer feasible.
} 
The geologic formations were examined and mapped in the field to determine in detail the extent and physical character of the unconsolidated water-bearing materials and to determine the extent and general character of the consolidated and generally non-water-bearing formations.

To secure additional critical data necessary for the completion of this investigation, the Water Resources Division of the Geological Survey augered 19 shallow test wells for a total depth of 621 feet, and drilled 7 deep test wells and 1 test hole, aggregating 2,800 feet. In addition, the Geologic Division of the Geological Survey, in connection with another investigation, drilled a 700 -foot test hole.

Utilizing these data the perennial yield was estimated, and suggestions have been included for refining the estimate.

This investigation was carried on by the Water Resources Division of the Geological Survey, United States Department of the Interior, during 1952-55 under the general supervision of J.F. Poland, district geologist in charge of ground-water investigations in California, and under the immediate supervision of G. F. Worts, Jr., geologist in charge of the Long Beach subdistrict office.

\section{Location of the Area}

The area under consideration in this report comprises Indian Wells Valley, Coso Basin, Rose Valley, and Salt Wells Valley. This area is in the western part of the Mojave Desert along the eastern side of the Sierra Nevada near the junction of Kern, Inyo, and San Bernardino Counties (fig. 1). The area is about 125 miles north of Los Angeles and 60 miles northeast of Mojave. The boundaries of Indian Wells Valley are between lat $35^{\circ} 25^{\prime}$ and $36^{\circ} 15^{\prime} \mathrm{N}$., and long $117^{\circ} 25^{\prime}$ and $118^{\circ} 10^{\prime} \mathrm{W}$. The main topographic features of the valley are shown on the Searles Lake quadrangle, scale 1:250,000, of the Geological Survey. Detailed features of the area are shown on parts of the Haiwee Reservoir, Coso Peak, Little Lake, Mountain Springs Canyon, Trona, Onyx, Inyokern, Searles, Searles Lake, Cross Mountain, Saltdale, and Randsburg quadrangles at a scale of $1: 62,500$.

The area considered in detail comprises the flat playas and alluvial slopes of Indian Wells Valley together with parts of the surrounding mountains and hills with their fans and bajadas. ${ }^{2}$

${ }^{2}$ Bajadas, as defined by Gilluly, Waters, and Woodford (1951, p. 353), are compound alluvial aprons along mountain bases. The bajadas flatten gradually valleyward and merge imperceptibly with the valley floor. 


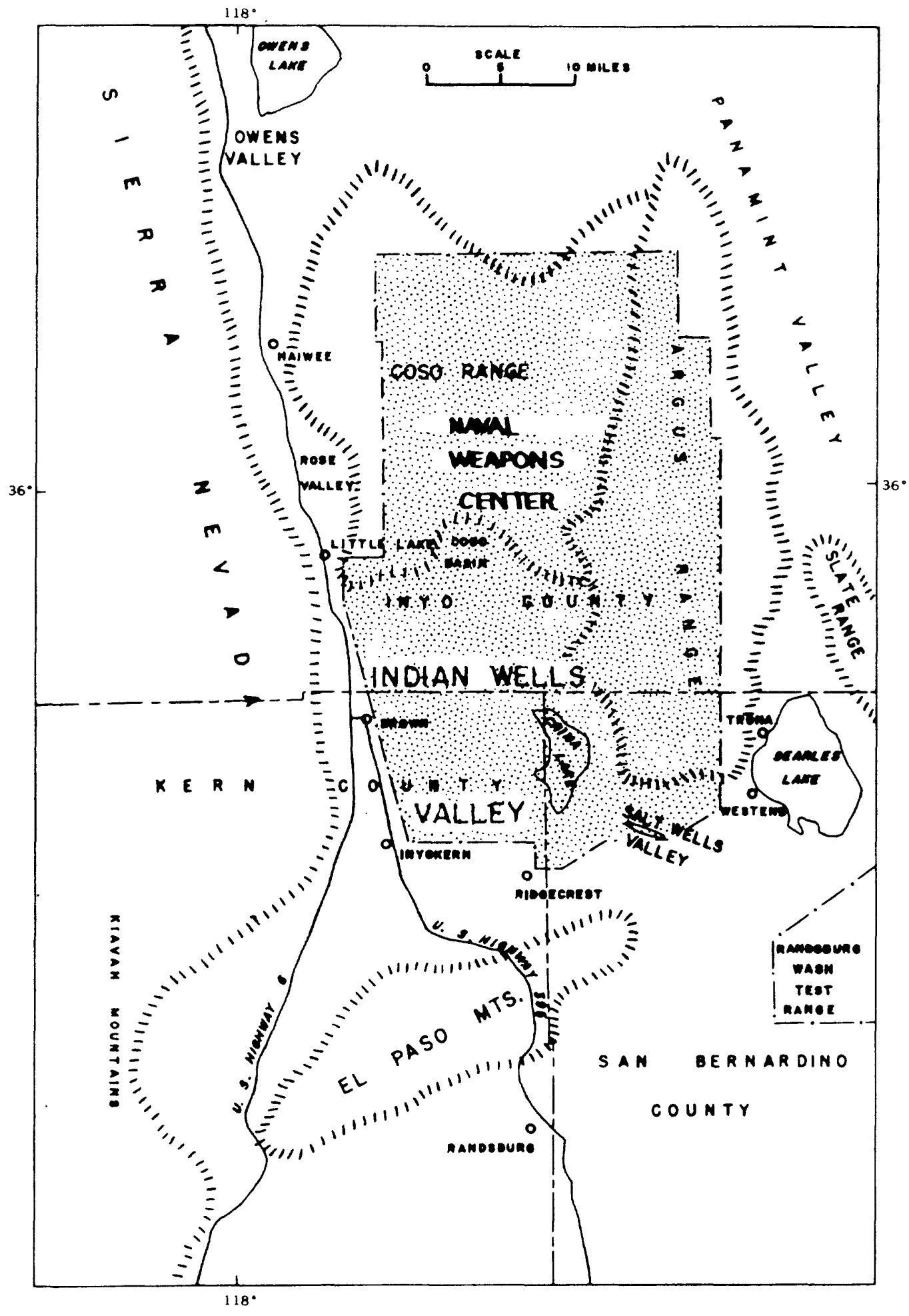

FIGURE 1...Indian Wells Valley area. 


\section{Previous Work}

The earliest hydrologic work in Indian Wells Valley was in 1912 by Lee (1913). Further work was done in 1920 by Thompson (1929) and in 1921 by Whistler (1923). Each of these investigators assembled important hydrologic data, but only Lee attempted an estimate of perennial yield.

Following the establishment of the Naval Weapons Center at China Lake in 1943, Buwalda (written commun., 1944), Bailey (1946), and Wilcox, Hatcher, and Blair (1951) conducted hydrologic investigations and released reports related to the water supply of Indian Wells Valley.

Thompson (1929) mapped the geologic formations in Indian Wells Valley in a reconnaissance manner, Samsel (1950) mapped the southeast quarter of the Cross Mountain quadrangle, and Dibblee (1952) mapped the Saltdale quadrangle in detail. Several other geologists have worked in the area, but, with the exception of Dibblee, their work has been very sketchy. For the most part, the geologic formations in Indian Wells Valley were generally unmapped.

\section{Acknowledgments}

Data from the work of Lee (1913), Thompson (1929), Whistler (1923), Bailey (1946), and Wilcox, Hatcher, and Blair (1951) were used, and part of their information has been incorporated in this report. The collection of additional data on wells and the use of water were greatly facilitated by the cooperation of Messrs. H. Hellmers and L. Blackmun of the Westend Chemical Co., Messrs. W. Turnbul, G. Wiggins, and J. McCall of the American Potash and Chemical Co., Mr. C. Ives of the Inyokern Water District, Mr. E. Fox of the Ridgecrest Water Co., the California Electric Power Co., Mr. O. Siebenthal and numerous other well owners and property owners who freely supplied information for this investigation.

The authors in particular wish to express appreciation to Commander Cunniff Mr. M. C. Lipp, Planning Division Head; Mr. M. J. Snow, Assistant Division Head Mr. E. G. Hannon, Design Section; and other personnel of the Public Works Officof Naval Weapons Center, China Lake, Calif., for their assistance in frequently supplying special equipment and services which facilitated the efficient and rapid completion of many phases of this project.

The section on evapotranspiration was examined by H. F. Blaney, Senior Irrigation Engineer, U.S. Department of Agriculture, Los Angeles, Calif., and we gratefully acknowledge the constructive suggestions and data supplied by him 
The authors also acknowledge the assistance of their colleagues of the Geoiogical Survey, principally W. J. Hiltgen, who located and measured most of the wells, conducted the pumping tests, and assisted in many other phases of the work; and W. L. Burnham and R. F. Boss, who assisted in pumping tests and test drilling. Joseph Lee of the Topographic Division, Geological Survey, furnished altitudes of land surface at many wells. Ward Smith and Waldon Pratt of the Geologic Division, Geological Survey, furnished detailed data on a deep test well drilled by them.

\section{GEOGRAPHY}

\section{Topographic Features and Drainage}

Indian Wells Valley is a structural and topographic depression on the east side of the steep escarpment of the southern Sierra Nevada, which reaches altitudes of 6,000 to 8,000 feet in this area. The area considered (fig. 2) is bounded on the east by the Argus Range, which reaches altitudes of over 5,000 feet, and on the south by the El Paso Mountains, whose peaks are 4,000 to 5,000 feet above mean sea level. On the north Indian Wells Valley is separated from Coso Basin by a low ridge and a still lower narrow divide, and from Rose Valley by the Coso Range. On the southeast low ridges separate Indian Wells Valley from Salt Wells Valley (fig. 1). Most of the central part of the valley is less than 2,400 feet above mean sea level. The east-central part of the valley is occupied by low playas, the largest and lowest of which is China Lake at an altitude of 2,152 feet above mean sea level.

The striking physiographic features of the valley are the steep fault scarp along the base of the Sierra Nevada and the broad alluvial fans that extend from the mouths of the Sierra Nevada canyons. These fans, which have coalesced to form bajadas several miles wide, slope with gradually decreasing steepness from the escarpment eastward toward playas along the east side of the valley. Along the western margin of the playa area small sand dunes are common. Deposits of sand dotted with small hollows, in which playa deposits are revealed, form a transitional zone between the toes of the fans and the large east-central playas.

In the southern part of Indian Wells Valley a low ridge underlies Ridgecrest and much of the residential area of the Naval Weapons Center. On the southwest an elevated spur of the valley separates the E1 Paso Mountains from the Sierra Nevada. Elsewhere on the south coalesced fans form a bajada sloping gently northward from the Rademacher Hills and the E1 Paso Mountains. A topographic low exists south and east of Ridgecrest surrounding the dry playas known as Mirror and Satellite Lakes. 
At the north end of the valley almost no alluvial cover is found on the gently southward-sloping basalt flows and older lacustrine deposits. On the west side of the valley the basalt flows are separated from the steep escarpment of the Sierra Nevada by a deep stream channe1 (probably a former channe1 of the ancestral Owens River). During periods of stream runoff from Rose Valley, the water crosses the toe of the basalt flows; at one point the water plunges over a small waterfall to reach the valley floor. Along the east side of the channel nearly vertical bluffs mark the margin of the thickest basalt flows.

Coso Basin is also a topographic depression whose lowest part is occupied by a dry lake. The basin is bounded by the Argus Range on the east, by the Coso Range on the north, by basalt and older 1acustrine deposits on the southwest and south, and by extensive alluvial fans on the southeast. Around much of its perimeter extremely steep slopes mark the basin limits, but on the southeast side the extensive fans of the Argus Range separate Coso Basin from Indian Wells Valley by a low divide. No surface runoff from Coso Basin reaches Indian Wells Valley.

Rose Valley, which is more nearly isolated from Indian Wells Valley, is an extension of the Owens Valley structural trough. On the west it is bounded by the escarpment of the Sierra Nevada, on the east by the Coso Range, and on the southeast by volcanic flows. Rose Valley is tributary to Indian Wells Valley, and, during periods of infrequent storms, stream runoff discharges through Little Lake into Indian Wells Valley.

Indian Wells Valley has entirely internal drainage. Many small streams in the canyons of the Sierra Nevada convey runoff to the fans where, after crossing the Sierra Nevada fault zone, the seepage loss becomes recharge to the ground-water body. Recharge to the ground-water reservoir is also derived from the runoff of the Argus Range and from surface runoff and underflow from Rose Valley at Little Lake.

A narrow gorge, now part of the Salt Wells Valley drainage, once afforded the lowest exit for surface drainage from Indian Wells Valley. The divide on this gorge, now filled with windblown sand, has a surface altitude of 2,190 fee In secs. 30 and 31 of T. 26 S., R. 41 E., a granite ridge at an altitude of about 2,400 feet marks the apparent site of rapids of another outlet through which discharge occurred in an earlier period when lake level was above 2,400 feet.

The total drainage areas for Indian Wells Valley, Coso Basin, and Rose Valley are 900,240 , and 180 square miles. Salt Wells Valley, an area of about 60 square miles, lies topographically below Indian Wells Valley. 


\section{Climate}

The climate of Indian Wells Valley is arid. Most of the precipitation on the valley floor falls as rain. Light precipitation occurs only during the period October-March; during the remainder of the year virtually no rain falls. December is the month of heaviest precipitation. Table 1 gives yearly precipitation by water years (October 1-September 30 ) for 2 stations in Indian Wells Valley and 3 nearby stations.

Records of precipitation at Armitage Field for the period October 1 , 1945-September 30, 1953, and at Inyokern for the period October 1, 1948September 30,1953 , indicate a short-term average annual precipitation for the lower part of the valley of about 2 inches. However, the period of record for these stations includes a series of dry years. Therefore, in a longer and more truly representative period the average annual precipitation may be somewhat greater.

For altitudes greater than that of the lower valley the increase in annual precipitation was estimated by Lee (1913) to be at the rate of 0.41 inch per 100 feet for the area west of Brown. On this basis, he estimated the annual precipitation at Brown (altitude, 2,395 ft) as 4 inches, at the base of the Sierra Nevada west of Brown 6 inches, and at the summit 22.5 inches. For the summit of the Argus Range Lee estimated that the average annual precipitation would be not more than 15 inches. During the winter most of the precipitation in the mountains falls as snow. An isohyetal map of California by the California State Water Resources Board (1951) indicates 15-20 inches of annual precipitation for the higher Sierra Nevada west of Inyokern.

Hot days and cool evenings and nights characterize the summers of Indian Wells Valley; warm days and cold nights are customary in the winters. According to Thompson (1929), early partial records kept by Mr. Harry Joos at his ranch in sec. 26, T. $26 \mathrm{~S} .$, R. $39 \mathrm{E}$. , from 1910 to 1921 , show a maximum summer temperature of $118^{\circ} \mathrm{F}$ and a minimum winter temperature of $8^{\circ} \mathrm{F}$. From July 1948 through September 1953 the maximum and minimum temperatures recorded at Inyokern were $117^{\circ}$ and $6^{\circ} \mathrm{F}$, according to records of the U.S. Weather Bureau.

Temperature records obtained at Armitage Field for the 6-year period 1946-51 by the Atmospheric Studies Branch, Naval Weapons Center, are summarized in table 2.

Mean hourly wind velocities at Armitage Field computed from graphs prepared by the Atmospheric Studies Branch represent compilations from continuous recorder charts for the 6-year period 1946-51. For the entire period of record the mean hourly velocity has been $9.8 \mathrm{mph}$ (miles per hour). These data are shown in table 3 . 
TABLE 1.--Annual rainfall (water year October 1-September 30), in inches, at representative stations in and near Indian Wells Valley

[From publications of the U.S. Weather Bureau]

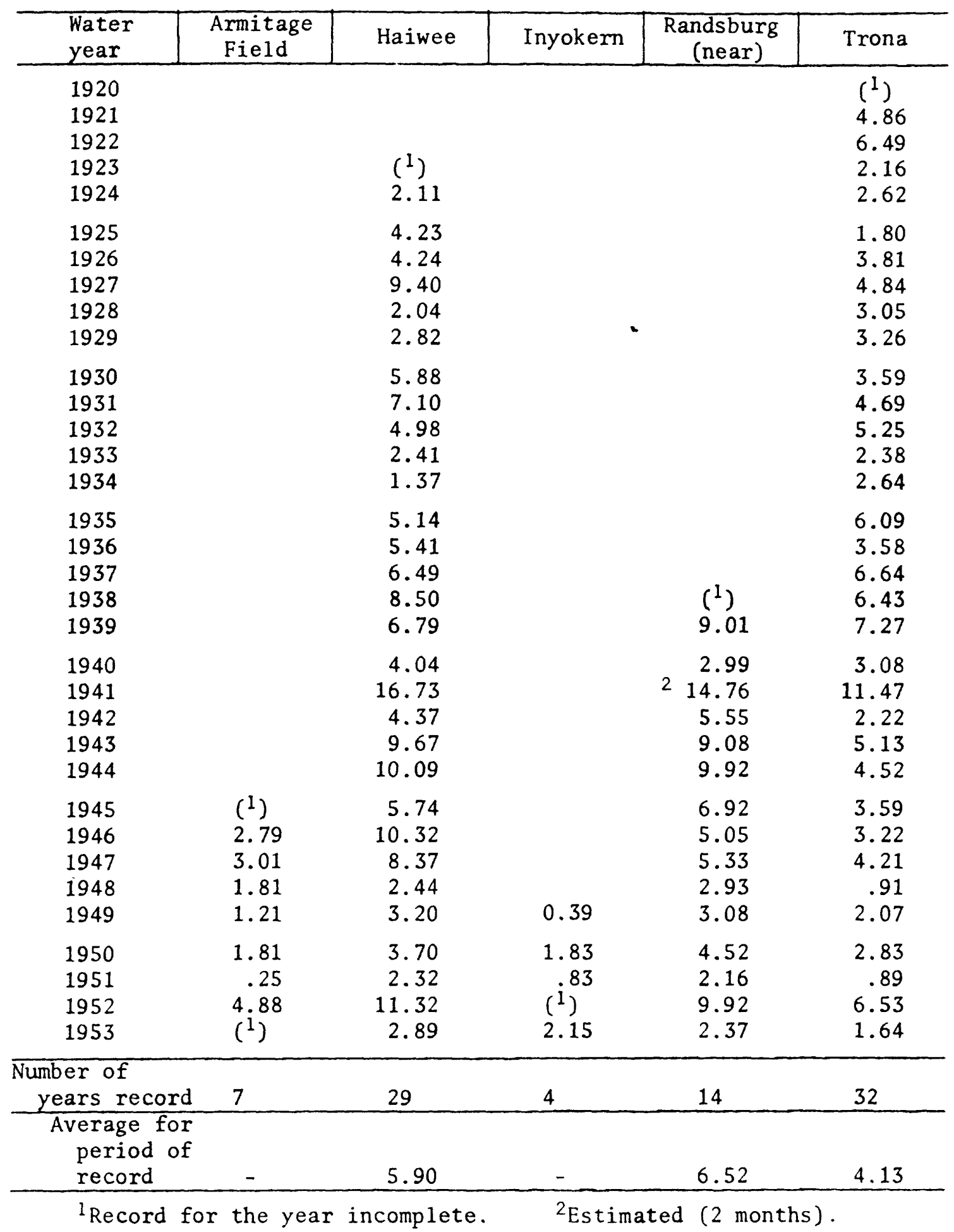


TABLE 2.--Temperature sumary, in ${ }^{\circ} \mathrm{F}$, for the 6-year period 1946-51 at Armitage Field

[Records from Atmospheric Studies Branch, Naval Weapons Center]

\begin{tabular}{l|c|c|c|c|c|c|c}
\hline Month & Highest & Lowest & $\begin{array}{c}\text { Average } \\
\text { high }\end{array}$ & $\begin{array}{c}\text { Average } \\
\text { Average } \\
\text { low }\end{array}$ & Mean & $\begin{array}{c}\text { Average } \\
\text { number } \\
\text { days with } \\
\text { low of } 32^{\circ} \mathrm{F} \\
\text { or less }\end{array}$ & $\begin{array}{c}\text { number } \\
\text { days with } \\
\text { high of } 100^{\circ} \mathrm{F} \\
\text { or more }\end{array}$ \\
\hline January & 77 & 9 & 56.0 & 29.0 & 42.5 & 21.5 & 0 \\
February & 80 & 14 & 62.7 & 34.0 & 48.3 & 11.0 & 0 \\
March & 84 & 22 & 66.4 & 40.7 & 53.5 & 4.3 & 0 \\
Apri1 & 97 & 30 & 79.1 & 50.2 & 64.6 & .3 & 0 \\
May & 107 & 40 & 85.1 & 56.9 & 71.0 & 0 & 1.7 \\
June & 113 & 50 & 94.4 & 64.5 & 79.4 & 0 & 6.7 \\
July & 111 & 59 & 101.0 & 71.0 & 86.0 & 0 & 20.0 \\
August & 110 & 54 & 99.4 & 67.4 & 83.4 & 0 & 16.5 \\
September & 110 & 40 & 93.8 & 62.3 & 78.0 & 0 & 9.7 \\
October & 96 & 32 & 80.0 & 50.0 & 65.0 & .2 & 0 \\
November & 85 & 21 & 68.2 & 38.0 & 53.1 & 6.2 & 0 \\
December & 75 & 13 & 57.8 & 31.6 & 44.7 & 17.5 & 0 \\
\hline Year & 113 & 9 & 78.7 & 49.6 & 64.1 & 61.0 & 54.6 \\
\hline
\end{tabular}

TABLE 3.--Mear hourly wind velocities at Armitage Field for the 6-year period 1946-51

[Records from Atmospheric Studies Branch, Naval Weapons Center]

\begin{tabular}{l|c|l|c|l|c}
\hline Month & $\begin{array}{c}\text { Velocity } \\
\text { (mph) }\end{array}$ & Month & $\begin{array}{c}\text { Velocity } \\
\text { (mph) }\end{array}$ & Month & $\begin{array}{c}\text { Velocity } \\
\text { (mph) }\end{array}$ \\
\hline January & 8.0 & May & 11.9 & September & 8.6 \\
February & 9.6 & June & 11.4 & October & 8.7 \\
March & 12.2 & July & 10.3 & November & 7.4 \\
April & 11.2 & August & 10.5 & December & 7.1 \\
\hline
\end{tabular}


Official weather observers at Armitage Field report that wind velocities are high in Indian Wells Valley and prevailing winds from the southwest create a persistent funneling effect between the El Paso Mountains and the Sierra Nevada; more rarely, a second funneling effect occurs through the Little Lake area. The Armitage Field weather station is sufficiently distant from the origin of both effects to permit measurement of the resultant valleywide velocities without interference due to more localized high-velocity currents. Wind velocities at Armitage Field in excess of $25 \mathrm{mph}$ have been recorded for all months of the year, and wind velocities in excess of $50 \mathrm{mph}$ have been recorded in all months between october and June.

\section{Early Development and Culture}

The drainage basin of Indian Wells Valley includes about 900 square miles, of which about 300 square miles is valley floor. Lee (1913) reported that in 1912 about 132 sections or about 83,000 acres had been filed on in the U.S. Land office. About one-fifth of this area had been cleared of brush, improvements had been made on about one-fourth of the acreage, and more than a hundred wells had been drilled.

Thompson (1929) reported that in 1916 about 12,500 acres had been patented and entries made for 49,800 additional acres; however, in 1919 only 800 acres were under cultivation, and he stated that, although some of the ranches had been established for 5-10 years, only a small quantity of produce had been marketed.

Lee (1913), Thompson (1929), and Bailey (1946) have all contended that only limited agricultural development will be possible in the valley because of the poor quality of the ground water for irrigation, the limited quantity of water, and the impermeability of many of the soils.

When the Department of the Navy took possesion of much of the valley in 1943, only a few farms were operating, according to Wilcox, Hatcher, and Blair (1951). Their report, which deals with the quality of water in Indian Wells Valley, states that in 1946 a few farms were still operating and that most of the wells canvassed seemed to have been unused for a long time. Alfalfa was in good condition on permeable soils, but only fair on the less permeable soils.

During the present (1952-55) investigation, not more than six moderately successful farms were noted. In 1953 about 400 acres were under cultivation. Four farms seemed to produce good stands of alfalfa, which was almost the only crop. 
The old stage route from Mojave to Keeler runs along the western border of the valley past "Indian Wells" (fig. 2), the springs for which the valley was named. The Los Angeles Aqueduct, bringing water from Owens Valley to Los Angeles, has been cut into the escarpment of the Sierra Nevada from Little Lake to Indian Wells. South of Indian Wells it skirts the base of the Sierra Nevada. The Owenyo branch of the Southern Pacific Railroad passes through the western part of the valley from Little Lake to Inyokern, from where it runs southeast to Rademacher Siding, and thence leaves the valley.

Two highways traverse the valley from south to north. U.S. Highway 395 crosses the Rademacher Hills to enter the valley south of Ridgecrest. U.S. Highway 6 passes through Red Rock Canyon to traverse the valley high on the bajada of the Sierra Nevada. The two highways join west of the small settlement of Brown.

Inyokern and Brown were the first communities established in the valley. Brown is now (1953) nearly a ghost town, but Inyokern, which has a population of about 800 , serves as a center for much of the valley. More recently the unincorporated town of Ridgecrest, which has a population of about 2,000, has grown up in the vicinity of the Naval Weapons Center, and is the largest civilian community in the valley. The weapons center, which was established in 1945, had a population in 1953 of about 10,000.

\section{Water Use}

All agriculture in Indian Wells Valley requires water for irrigation, and it is generally agreed that from 2 to 7 acre-feet of water per acre per year is necessary to raise crops, depending on the crop and the condition of the soil. Prior to 1944 the main use of ground water in Indian Wells Valley was for irrigation. Since 1944 the main use of ground water has been for public supply or domestic use, and, by comparison, irrigation has become of secondary importance.

Irrigation, though still important, is of limited extent because of low permeability of the soil in many places, surface concentration of alkali in other places, excessive pumping lifts on the upper fans, poor water quality in local areas or zones, and limited yields of wells in some parts of the valley. However, a part of the now unproductive areas outside the boundaries of the weapons center, if properly developed, probably would yield large quantities of water of good quality for irrigation. 
GEOLOGY

Geologic Formations and Their Water-Bearing Properties

In this report the geologic formations of Indian Wells Valley are described from oldest to youngest with particular reference to their waterbearing character. The geologic map (fig. 2) shows the areal distribution of these formations. Their stratigraphic relations are shown on the geologic sections (figs. 3 and 4 ).

Basement Comp1ex

The rocks of the basement complex are the oldest rocks that crop out or are penetrated by wells in Indian Wells Valley. These rocks are considered to range in age from Paleozoic to late Mesozoic. The granite, granodiorite, and metamorphic rocks that form the Sierra Nevada are chiefly Jurassic in age or older (Louderback, 1924). Known Paleozoic rocks southeast of Terese Siding are probably the oldest in the area. Hulin (1925) shows that Paleozoic rocks form the southwest half of the El Paso Mountains and Jurassic quartz monzonites the remainder. Elsehwere in Indian Wells Valley quartz monzonite, quartz diorite, granodiorite, and other granitic types of rocks are generally considered to be Jurassic in age (Hulin, 1934). Numerous acid and basic dikes and dike swarms also occur throughout the area, and the most recent of these intrusive rocks may be contemporaneous with recent movement of considerable extent along the major fault zones and may be as recent as Pliocene to Pleistocene in age (Louderback, 1924). However, in general, only where dikes indicate structure are they distinguished from the basement complex.

Rocks of the basement complex, shown in figure 2, occur along the west side of Indian Wells Valley west of the Sierra Nevada fault zone, east of Little Lake in the Coso Range, in part under basalt flows, along the east side of Indian Wells Valley in the Argus Range, and south of Ridgecrest in the E1 Paso Mountains.

None of the rocks of the basement complex can be considered as bearing significant quantities of ground water, although minor quantities may percolate through cracks and fractures. The basement complex is important in that it surrounds the main valley area and forms the sides of most of the marginal area of Indian Wells Valley which receives the major part of the precipitation that falls within the valley drainage basin. The runoff from this marginal and mountain area flows onto the steep alluvial fans and contributes the largest amount of recharge to the ground-water body. The rocks of the basement complex also form the structural basin which is filled with the deposits of Tertiary and Quaternary age. 


\section{Continental Deposits}

Definition and age.--Continental deposits, of Tertiary age, rest with angular unconformity on the basement complex and are overlain unconformably by the Black Mountain Basalt, older alluvium, and younger alluvium.

The units that comprise the continental deposits as described by Dibblee (1952) and Merriam (1914) range in age from Paleocene to Pliocene. They include indurated fluviatile and lacustrine sediments and extrusive and instrusive volcanic rocks.

Distribution and origin.--The continental deposits crop out on the northeast side of the El Paso Mountains south of Terese Siding and extend to the southern limits of present mapping. About 2 miles east of Terese Siding sediments of this series are found beneath two basalt-capped outliers; these are the easternmost exposures found in the course of this investigation. These deposits presumably occur to the north and northwest beneath the alluvial fan deposits at depths, increasing northward from the contact with the fan deposits on the south and southeast, and presumably are cut off on the northwest at the contact with the Sierra Nevada fault zone. A well drilled in March 1954 half a mile west of well 28/38-18 was reported to have penetrated clayey, non-water-bearing deposits from approximately 600 to 930 feet. These are probably continental deposits. According to Lee (1913, p. 407) an oil prospect hole, well 27/39-16F1, reportedly penetrated clay and shale at shallow depth and was drilled to 1,935 feet in sediments of this type. Presumably this hole penetrated the continental silts and tuffs of the middle part of the Ricardo Formation as described by Dibblee (1967). It is not known whether the continental deposits extend northward beneath the central part of Indian Wells Valley.

Lithology.--The continental deposits as mapped comprise the Goler and Ricardo Formations. The Goler Formation, as described by Dibblee (1967), is a section 6,500 feet in total thickness. The lower member of the Goler Formation is composed of 500 feet of unsorted fanglomerate made up of wellrounded boulders and cobbles up to 2 feet in diameter composed of granitic rocks, quartzite, chert, limestone, and aphanitic porphyries. The upper member is made up of 2,000 feet of clay and sand overlain by 4,000 feet of interbedded clay, sand, and gravel. The clay is generally maroon in color, rarely greenish, silty to sandy, and in beds up to 15 feet thick. The sand is arkosic, buff colored, well bedded, unindurated, and with cavernous weathering. The sand also may contain many dark brown concretions up to 2 feet in diameter and it commonly is pebbly in beds up to 50 feet thick. The gravel occurs in beds up to 500 feet thick and is generally gray; it is made up of well-rounded cobbles up to a foot in diameter of quartzite, chert, limestone, granitic rocks, and aphanitic porphyries of dacite, andesite, and basalt. It is further reported by Dibblee (1952) that the upper member contains many wood fragments and some carbonaceous material and that the base of the formation locally contains about 20 inches of soft coal with which fossil leaves are associated. 
The Ricardo Formation, which unconformably overlies the Goler Formation, is reported by Dibblee (1952) to have a total maximum thickness of 7,000 feet and to consist of a basal arkosic conglomerate of fluviatile or subaerial origin, a middle part composed of a series of pyroclastic sedimentary rocks, volcanic conglomerate, lava flows, interbedded with terrestrial deposits, and an upper part made up of terrestrial or lacustrine deposits.

As described by Dibblee (1952) the basal conglomerate of the Ricardo Formation consists of 50 to 500 feet of light green-gray conglomerate made up of rounded cobbles as much as 18 inches in diameter of predominantly granitic rocks. The middle part of the formation consists of several members that may total as much as 3,000 feet in thickness, consisting of approximately 600 feet of well-bedded white tuff and ash, orange-pink to gray-white tuff-breccia, and andesite lava flows separated by gray-white tuff-breccia; up to 1,100 feet of pink-gray cross-bedded conglomerate made up of cobbles of pink to brown rhyolite, andesite, and basalt-andesite interbedded with a 30 -foot lens of white tuff-breccia; up to 600 feet of lacustrine deposits interbedded with beds of soft ash; and 200 to 1,000 feet of interbedded tuff-breccia, basalt flows, lacustrine deposits, tuffaceous sand and silt, and pink-gray sandstone. The upper part of the formation consists of 3,000 to 5,000 feet of terrestrial or lacustrine deposits as follows: Up to 2,000 feet of bedded light pink-gray sand, calcareous sandstone, and layers of brown gravel of andesite pebbles; 1,500 feet of lacustrine nodular clay and interbedded gray-white tuffaceous siltstone and opalized mud; and 1,500 feet of light-gray granitic gravel, sand, and light brown micaceous gritty clay.

Water-bearing properties.--In general because the continental deposits are indurated and poorly sorted, ground water does not occur in them in significant. quantities. Water undoubtedly occurs in fractures beneath the water table and, in some lenses which are undoubtedly more permeable than others. However, except for very small yields of water, as penetrated in wells $27 / 38-36 \mathrm{~F} 1$ and $28 / 38-33$, the deposits may be considered as virtually non-water-bearing.

\section{Black Mountain Basalt}

The Black Mountain Basalt consists of extrusive and intrusive olivine basalt flows, both vesicular and compact, and more than 100 feet thick, named by Baker (1912) for their occurrence on Black Mountain about 7 miles west of the El Paso Mountains. Outside the area mapped, these basalt flows intrude the upper Miocene or lower Pliocene Red Mountain Andesite of Hulin (1925) and unconformably overlie the Ricardo Formation. The age of these flows cannot be dated closer than between late Pliocene (Hulin, 1925) and Pleistocene (Dibblee, 1967).

Residual cappings of Black Mountain Basalt and the agglomerates derived from it unconformably overlie the entire section of the continental deposits and cap the highest areas north of the El Paso Mountains. Their present distribution indicates an extensive flow originally covering at least 50 square miles in Tps. 27 and $28 \mathrm{~S}$., and Rs. 38 and $39 \mathrm{E}$. 
The Black Mountain Basalt is an olivine basalt, brown to black in color, dense, hard, and generally not excessively vesicular in this area. Many of the cappings mapped as Black Mountain Basalt seem to be agglomerates or landslides with only a slight displacement from their original position.

Because of its elevated position above the water table, lack of continuity of outcrop, and general impermeability, the Black Mountain Basalt is not considered as a source of ground water.

Older Alluvium

Definition and age.--The older alluvium is composed of undeformed to moderately deformed lenticular deposits of semiindurated silt, sand, gravel, and boulders. These deposits (fig. 3) are over 800 feet thick, the maximum thickness being unknown (section $C-C^{\prime}$ ).

Where observed the older alluvium generally overlies unconformably the basement complex or the continental deposits, and it underlies younger alluvium and fan deposits. Where exposed the older alluvium stands above stream channels and washes, and when the area receives precipitation the older alluvium is subject to exosion or dissection. Around the margins of the valley the older alluvium seems to be separated from the younger alluvium by an erosional unconformity. The older alluvium is considered to be early to middle Pleistocene in age, but the lowermost part may be late Tertiary in age.

Distribution and origin.--The older alluvium is well exposed in two areas in Indian Wells Valley--one is south of Little Lake and west of U.S. Highway 6 in Tps. 23 and $24 \mathrm{~S}$., and the other is west of U.S. Highway 6 in Tps. 28 and $29 \mathrm{~S}$. and mostly outside of the drainage area of Indian Wells Valley. There are also a few scattered outcrops or windows of what may be older alluvium surrounded by fan deposits in the central part of T. $27 \mathrm{~S}$., R. $38 \mathrm{E}$. These deposits also may be continuous along the west side of the valley but masked by a veneer of younger alluvium. Where exposed they seem to represent remnants of a once-continuous deposit of older alluvial fans graded to a lower base level than the present floor of China Lake. However, it is not known whether the change in base level or grade was a result of faulting, change in rate of precipitation, fluctuation of lake levels, or damming of old drainage courses by the post-1acustrine basalt.

Lithology. - Where exposed south of Little Lake the older alluvium consists of granodiorite boulders, commonly in lenticular zones, interbedded with cross-bedded silt and fine to coarse granitic sand and gravel. No pebbles of basalt or other volcanic rocks have been observed in the gravel or sand of the northern exposures of the older alluvium. In general, coarse pebble-boulder conglomerate, containing individual boulders up to 3 feet in diameter, and coarse sand make up the bulk of the northern exposures. The deposits in Tps. 28 and $29 \mathrm{~S}$. are not well exposed but are chiefly composed of arkosic sand debris from the granite and granodiorite of the basement complex. Furthermore, these deposits are generally cemented by clay minerals resulting from the decomposition of the feldspar in the deposit. 
Older alluvium presumably occurs at depth beneath the younger alluvium and also beneath the younger and locally the older lacustrine deposits in the central part of Indian Wells Valley. However, it is generally impossible to distinguish a lithologic break or change in drillers' logs of wells that are known to start in younger alluvium and presumably penetrate older alluvium at depth.

Wells drilled in the younger lacustrine deposits generally have not penetrated older alluvium at depth. Well 25/40-25Pl (Moyle, 1963, p. 201) was drilled by the Geologic Division of the Geological Survey to a depth of 700 feet. The $\log$ of this well indicates younger and older lacustrine deposits to 700 feet. However, if this well had been drilled deeper, it might have penetrated older alluvium. Well 26/40-22P1 (fig. 3, section $B-B^{\prime}$ ) drilled to a depth of 1,358 feet penetrated older lacustrine deposits to a depth of 530 feet, presumably older alluvium between 530 and 1,350 feet, and bedrock below 1,355 feet. The log of this well (Moyle, 1963, p. 231) shows the older alluvium to be an alternating sequence of sand, silt, and clay with one gravel lens between 594 and 616 feet.

Water-bearing properties.--Where the older alluvium occurs beneath the water table all the pore spaces in the deposit are saturated with water. However, because these deposits, where exposed, are generally cemented by clay minerals formed from the decomposition of the feldspars in the deposit and subsequently compacted, the permeability of these deposits probably is low.

We11s $27 / 38-1 M 1,27 / 38-28 R 1,27 / 38-31 D 1,28 / 37-13$, and $28 / 38-18$, in the southwest part of the valley, all probably penetrate older alluvium beneath the water table and all yield small quantities of water, apparently of satisfactory quality for limited domestic and stock needs. Logs are not available for wells drilled in the older alluvium in the west and southwest part of the area; however, wells drilled in these deposits probably would yield sufficient water for irrigation.

Test well 26/40-22Pl drilled in the central part of the valley presumably penetrated older alluvium between 530 and 1,350 feet. The geologic log by the Geological Survey and the electric $\log$ indicate an alternating sequence of sand and thin clay layers from 530 to 830 feet. The test well perforated in this zone was never fully developed, but a properly constructed supply well drilled in this zone might produce as much as $1,000 \mathrm{gpm}$ (gallons per minute). From 830 to 1,350 feet the geologic $\log$ and the electric log indicate a greater quantity of clay than from 530 to 830 feet. Also, between 830 and 1,350 feet the electric $10 \mathrm{~g}$ indicates a low formational resistivity which probably indicates a highly saline water. Therefore, it is unlikely that potable water could be developed in this area below 830 feet. 


\section{Older Lacustrine Deposits}

Definition and age.--The older lacustrine deposits are predominantly silt and silty clay interbedded locally with thin beds of impure limestone, calcareous sandstone, conglomerate, and unindurated sand. They are in part interbedded with and in part overlie the older alluvium. The base of these deposits is nowhere exposed, but the deposits presumably overlie the basement complex and in part the older alluvium, and underlie the unnamed volcanic and younger alluvium. They crop out at altitudes between 2,230 and 2,750 feet; below 2,230 feet they are concealed by younger deposits.

The age of these deposits cannot be precisely determined. However, they are older than the unnamed volcanics which they underlie, and, because they are only moderately deformed and indurated, they are presumed to be younger than the more strongly deformed and indurated continental deposits. Also, inasmuch as these deposits are cut by a 2,240- to 2,260-foot shoreline, they must be older than the stage of the lake that cut that shoreline, which is correlated with the Tioga Glaciation as defined by Blackwelder $(1933,1941)$. (See section on geologic history.)

Distribution and origin.--The largest exposed area of these deposits occurs at the north edge of the valley south of Coso Lake. They also extend under the basalt flows to the west as indicated by one small outcrop along the north edge of the basalt and by one window several square miles in extent within the area of the basalt flow. Four tongues that seem to be the same type of deposit also crop out in washes along the east side of the valley in T. $24 \mathrm{~S}$. Similar deposits also occur east of the weapons center main gate as a conspicuous topographic ridge generally at an altitude above 2,240 feet. The extent of the ridge corresponds to the outcrop area of the older lacustrine deposits. These deposits also presumably occur at depth beneath younger lacustrine and playa deposits and beneath younger alluvium near the central part of the valley.

Little is known about the ancestral lake in which these deposits formed, but it probably was part of an early glacial-lake system that connected Owens, China, Searles, Panamint, and Death Valleys prior to the commonly described 2,240 - to 2,260-foot stage. No old shorelines associated with this lake were found that might have determined accurately its altitude. In addition, faulting without appreciable tilting may have raised the northernmost of these deposits, further complicating a determination of the altitude of the lake. However, this lake probably discharged to the east through a wide deep dry wash east of Ridgecrest and south of the weapons center boundary. The divide of the ancestral wash is now over 2,400 feet in altitude and was not the outlet for Lake China ${ }^{3}$ during the 2,240 - to 2,260-foot stage.

\footnotetext{
3 In this report the names Lake China and Lake Searles are used to indicate those lakes as they existed during the late Pleistocene time, whereas China Lake and Searles Lake indicate the present form of these lakes.
} 
Lithology. - The most complete exposed section of the older lacustrine deposits occurs along the weapons center access road south of Coso Lake. In general, these deposits from top to bottom show the following section: (1) Limestone, extremely light in weight, chalk white on fresh break, weathers in spindle-shaped closely spaced columns resembling algal or hot-spring deposits; (2) limy conglomerate, sandy limestone, and micaceous gray noncalcareous silt; (3) calcareous fine conglomerate; (4) medium to coarse calcareous sandstone and uniform medium-grained sandstone; and (5) coarse arkosic sandstone and conglomerate with micaceous gray silt.

A detailed measured section of the uppermost part of the older lacustrine deposits in secs. 6 and 7, T. 24 S., R. 40 E., is described below from top to bottom.

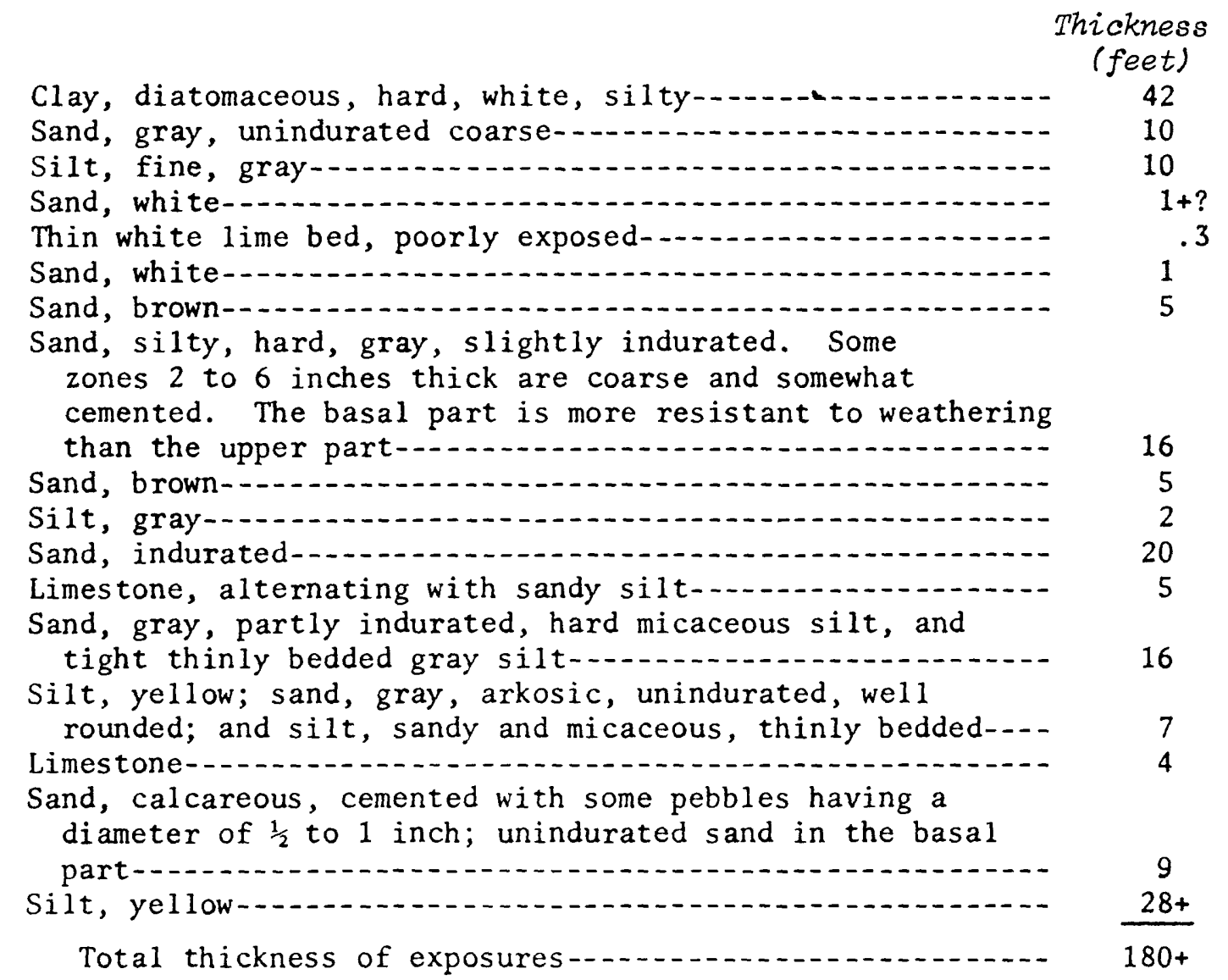

Along the east side of Indian Wells valley in T. 24 S., R. 41 E., four tongues of crossbedded sand interbedded with some silt and gravel crop out in washes. Because the calcareous beds are lacking, this material may be older (? alluvium. However, because these outcrops also lack coarse gravel, seem to be water laid, occur at an altitude between 2,260 and 2,700 feet, and seem to form a terrace, these outcrops were mapped as lacustrine deposits. 
East of the weapons center main gate and north of Mirror Lake along a conspicuous ridge, generally above 2,240 feet in altitude, various excavations for buildings, roads, and other structures have exposed a series of calcareous sand and gravel deposits and one outcrop of dense limestone. Except for the limestone outcrop, the material consists almost completely of calcareous poorly sorted sand and gravel beds. These deposits seem to be horizontal and generally unindurated or at most poorly indurated, but a few beds are very calcareous and hard. The pebbles that compose the gravel are mostly pink granite or granodiorite with some metasediments, and a very few are vesicular basalt. Only a few pebbles in these deposits exceed 1 inch in diameter.

Logs for the only three wells drilled in the older lacustrine deposits are for wells 25/40-25P1, 26/40-22P1, and 26/40-27M1 (Moyle, 1963, p. 201, 229, and 232). The $\log$ of well 26/40-27Ml indicates an alternating sequence of sand and "shale" to a depth of 260 feet. The "shale" of this well is probably a hard silt or clay.

Well 25/40-25P1 (fig. 3, section $F-F^{\prime}$ ) was drilled by the Geologic Division of the Geological Survey to a depth of 700 feet. This well is on the China Lake playa and presumably starts in playa deposits of Holocene age. However, the well probably penetrates younger lacustrine deposits of Pleistocene age at moderately shallow depth even though the contact cannot be identified, and a sequence of clay, silt, and thin lenses of sand below the younger lacustrine deposits that continue to a depth of 700 feet are presumably older lacustrine deposits.

Well cuttings and an electric log of well 26/40-22P1 (fig. 3, section $\left.E-E^{\prime}\right)$, drilled by the Navy as part of this ground-water investigation, indicate that the well started in the older lacustrine deposits and penetrated a section composed predominantly of clay and silt interbedded with thin beds of limestone to a depth of 530 feet. From 530 to 1,350 feet the electric $\log$ indicated an alternating sequence of unindurated sand, silt, and clay with one gravel zone between 594 and 616 feet. Bedrock was penetrated at approximately 1,355 feet. The well bottomed at 1,358 feet. Because this well starts in older lacustrine deposits, all the material from the surface to 530 feet is inferred to be older lacustrine deposits. As was indicated, from 530 to 1,350 feet the material is probably older alluvium.

Test wells 25/40-33L1 and 26/40-1A2 (Moyle, 1963, p. 212 and 224), drilled to depths of 171 and 198 feet, start in deposits of Holocene age, and even though a definite contact cannot be determined from the logs of these wells, they probably penetrate older lacustrine deposits.

Well 25/39-26H1, drilled to a depth of 302 feet, penetrated blue clay at 195 feet. The log of this well indicates an alternating sequence of blue or black clay and thin sand seams from 195 to 302 feet. Between 300 and 302 feet the $\log$ indicates a blue-black clay. The material in this well from 195 to 302 feet is probably a part of the older lacustrine deposits. 
Certain other wells near China Lake start in the younger alluvium, but are reported to penetrate a thick section of blue clay at depth. Most of these wells are reported to bottom in blue clay and yield little or no water. For example, it was reported that well $26 / 40-7 \mathrm{~F} 1$ was drilled to a depth of 850 feet without penetrating any water-bearing gravel, well 26/40-8N1 penetrated blue and white clay between 74 and 210 feet, well 26/40-10N1 penetrated blue clay between 106 and 350 feet with only a few seams of sand and fine gravel, well 26/40-18El penetrated blue clay between 92 and 750 feet, and well 26/40-20Gl penetrated blue clay at 112 feet. The clay in most of these wells is probably part of the older lacustrine deposits.

Water-bearing properties. - Where older lacustrine deposits occur beneath the water table all the pore spaces in the deposits are saturated with water. Locally the deposits may contain coarse uncemented sand that yields water freely to wells. Well 25/39-26H1 and test wells 24/40-33L1 and 26/40-1A2 apparently penetrated coarse zones in the lacustrine deposits at depth. However, wells, such as 26/40-8N1, 26/40-10N1, 26/40-18E1, 26/40-20G1, and the deep test well 26/40-22P1, penetrated very little water-yielding material in the older lacustrine deposits. Therefore, it seems that except locally the material generally penetrated in the older lacustrine deposits will not yield water freely to wells.

\section{Unnamed Volcanic Rocks}

Unnamed volcanic rocks at the northern end of Indian Wells Valley and north of Coso Basin comprise a group several hundred feet thick composed mostly of basalt flows interbedded in a few places with scoria, pumice, obsidian, and probably some andesite. These volcanic rocks are interbedded with the younger alluvium. However, in a limited area in the northwest corner of sec. 34, T. 24 S., R. 39 E., calcareous tufa (Twenhofel, 1932, p. 326) occurs at an altitude of approximately 2,240 feet, along a Pleistocene shoreline of Lake China, indicating that these flows were in existence before the 1ate Pleistocene Lake China of Blackwelder $(1933,1941)$.

The most prominent occurrence of these flows is at the north end of the valley, east of U.S. Highway 6 , and southwest of Coso Lake, extending into the southern part of Rose Valley and the Coso Basin. In this area the basalt flows overlie older lacustrine deposits, basement complex, and probably older alluvium. These rocks are locally covered by a veneer of windblown sand, and the south margin of the flows (fig. 4, section $G-G^{\prime}$ ) may be interbedded with younger alluvium. 
Evidence is not at hand to determine if these flows are correlative in age with the Black Mountain Basalt to the south. However, because these rocks are generally less weathered, occur at a lower altitude in conformance with existing topography, and locally may be interbedded with younger alluvium, they are probably younger than the Black Mountain Basalt.

Other flows and volcanic material that occur around Coso Lake and to the north and east of Coso Basin have not been mapped or examined in detail, but they probably are generally correlative with the unnamed volcanic rocks at the northern end of Indian Wells Valley.

The unnamed volcanic rocks seem to be derived from volcanic vents and fissures that generally occur at the north end of the area of these deposits. Most of these vents and the cones that surround them are indicated on the geologic map (fig. 2).

In the area southwest of Coso Lake there occur at least two flows-a lower basalt that shows greenish, rounded to subrounded olivine phenocrysts, and an upper basalt that shows angular lathlike crystals of feldspar (?). Upon weathering the lower extrusives are stained brown to red, the upper extrusive remains black. These flows are well exposed in canyons to the north of Coso Lake where they occur with a bedded series of basalt and scoria. In a quarry east of Coso Hot Springs a 10 -foot bed of white pumice is well exposed.

In general, the basalts of the unnamed volcanic rocks are dense and impermeable. Except for water in cracks and fractures, they are generally non-water-bearing. The scoria and pumice, where located beneath the water table, probably could yield water freely to wells; however, because they are generally of such limited extent and thickness, and are interbedded with dense basalt, they have not been explored as a source of ground-water supply.

Fan Deposits

Definition and age.--The fan deposits consist of lenticular beds of unconsolidated clay, silt, sand, gravel, and boulders in a heterogeneous mixture. The deposits mapped as fans are characterized by an abundance of locally derived very poorly sorted boulders, gravel, and sand. These deposits are also locally composed of mudflows. The surface slope of these fans usually exceeds 100 feet per mile and locally exceeds 200 feet per mile. Toward the central part of the valley the alluvial fans usually grade with a perceptible break in slope into the unit mapped as younger alluvium.

The fan deposits seen at the surface are Holocene in age. However, they are correlative with the younger alluvium and at depth are middle to late $\mathrm{Pleistocene}$ in age. 
Distribution and origin.--The fan deposits as mapped mainly underlie the steep part of the alluvial fans of the Sierra Nevada and to a lesser extent the alluvial fans of the other mountains surrounding Indian Wells Valley. These fans extend from the mountain canyons toward the central part of the valley and have coalesced to form bajadas. The alluvium in the large embayment west of the El Paso Mountains, which seems to merge without interruption or abrupt change into that of the lower valley and into neighboring fans, is also considered in this category. Also included with the fan deposits are those in the numerous small channels and washes that cross the fans and in the large channel of the stream south of Little Lake.

The transportation of debris from the surrounding mountains, both during earlier periods of greater average precipitation and during times of sheet flooding or cloudbursts, has been the principal process in the formation of the fans and bajadas of the valley; and in the areas of steep escarpments, rock creep and landslides have contributed some material to the valley margins. Activity along fault zones at the bases of bordering mountains, such as that of the Sierra Nevada fault zone, has increased the surface gradients and hence the carrying power of the streams so that coarse alluvial debris has been deposited adjacent to the mountain fronts. The vertical movement along the Sierra Nevada fault zone has occurred repeatedly, probably since Miocene time or earlier, and the total displacement has probably been several thousand feet.

Lithology.--The fan deposits consist of silt, angular sand, gravel, cobbles, and boulders. East of the Sierra Nevada the deposits are derived from the Sierra Nevada granitic and metamorphic rocks. The fan deposits south of the El Paso Mountains are derived largely from Paleozoic quartzite and limestone, whereas the fan deposits of the Rademacher Hills are derived largely from pegmatite, fine-grained granitic rocks, and less commonly from intermediate to basic intrusive rocks. The fan deposits of Coso Basin and those on the west side of the Argus Range consist of coarse angular debris of granodiorite and basalt from the north and east.

The channel deposits are not differentiated on the geologic map from the fan deposits or younger alluvium. They are mostly reworked and well-sorted sand and grave1 derived from the fan deposits; at the north end of the valley they include volcanic detritus derived from the unnamed volcanic rocks.

The thickness of the fan deposits is not known. East of the Sierra Nevada fault zone they are undoubtedly of great thickness--probably 1,000 feet or more. It was reported that a well in sec. $15, \mathrm{~T} .26 \mathrm{~S}$, , R. $38 \mathrm{E}$., only a few hundred feet east of the fault zone and drilled to a depth of 500 feet, failed to penetrate either bedrock or the water table. West of the Sierra Nevada fault zone the fan deposits are relatively thin pediment covers that range in thickness from 0 to 300 feet. 
Water-bearing properties.--Available hydrologic data for the fan deposits are insufficient for adequate consideration of their water-bearing properties, yet this very lack of information is significant. These deposits, although locally undoubtedly very permeable, pose difficulties for well construction and operation because of the great depth to the water table. In many places wells would have to penetrate hundreds of feet of unsaturated dry material before reaching water-bearing zones. So even though properly constructed wells in the deposits might locally yield water of similar quantity and quality to the best wells in the younger alluvium near Inyokern, the pumping lifts would be large.

In parts of the valley the fans are composed of poorly sorted mudflow debris which is of low permeability and yields little water to wells. In other parts of the valley the decomposition of feldspar minerals has caused a cementation of the fan deposits accompanied by a decrease in the permeability of the deposits. In other places older alluvium, which is generally of low permeability, would be penetrated above the water table. Therefore, in many areas wells drilled in the fan deposits probably would yield water at low rates sufficient only for domestic and stock wells.

Younger Alluvium

Definition and age.--The younger alluvium consists principally of lenticular beds of unconsolidated clay, silt, sand, and gravel, derived largely from the Sierra Nevada and to a lesser degree from the other mountains surrounding the central valley area. The slope of the younger alluvium is generally less than 100 feet per mile and for most of the area it is generally less than 50 feet per mile.

The younger alluvium at the surface is Holocene in age. Whenever cloudbursts swell canyon streams and sheet flooding occurs, new sediments are swept out onto the fans and occasionally to the valley floor. By this process active deposition in the valley is continuing. However, these deposits unconformably overlie the older alluvium; therefore, at depth, the younger alluvium is considered to be middle to late pleistocene in age.

Distribution and origin.--The younger alluvium as mapped consists of the fluviatile deposits east of the alluvial fans of the Sierra Nevada and valleyward from the fans of the other bordering mountains. It underlies all the valley floor except for the playa deposits and where overlain by windblown sand. The younger alluvium probably is interbedded with the playa deposits.

The younger alluvium was deposited by the distributaries of the canyon streams heading in the mountains surrounding Indian Wells Valley, particularly by those streams in the Sierra Nevada. In addition, the sediment load of the stream draining Rose Valley and its local distributaries contributed to the basin fill during late Pleistocene and Holocene times. Most of the younger alluvium contributed to the valley is below an altitude of 2,500 feet. 
During Pleistocene time, the so-called Owens River, which drained southward from Owens Valley to Indian Wells Valley, may have deposited sediments in Lake China, but the irregular distribution of coarse deposits northwest of China Lake and the lack of coarse deposits in China Lake suggest that deposition occurred chiefly in the distributary channels of streams crossing the alluvial fans and valley floor, and that occasional widespread deposition of coarse materials occurred during periods of large floods. Thus, in late Pleistocene and early Holocene time deposition was fluviatile or lacustrine in the marginal areas of shallow lakes covering parts of the basin. During times of little movement along the fault zones or during periods of greater aridity, deposition of fine-grained silty and argillaceous materials was predominant.

Lithology. -- The younger alluvium consists largely of arkosic, medium to coarse, angular to subangular sand, and angular to well-rounded gravel with interbedded or lenticular silt and clay. Some zones are moderately cemented, but most of the alluvium is unconsolidated. Pebbles, cobbles, and boulders are usually moderately rounded to well rounded, but the sand and fine gravel are usually angular. Wells in the vicinity of the basalt flows at the north end of the valley are reported to penetrate lava detritus. Well 25/39-4P1, whose total depth is 145 feet, penetrated lava boulders. Lee (1913) reports that the numerous fragments of lava brought up during the driliing of the wells in the north end of the valley were waterworn. Elsewhere the amount of lava detritus penetrated has evidently been negligible, although some debris must have been contributed to limited areas from the Black Mountain Basalt to the south.

Water-bearing properties.--The younger alluvium in general is composed of finer and better sorted debris than the fan deposits and is the chief reservoir for ground water in Indian Wells Valley. These deposits have a wide range in permeability. This range, as determined from pumping tests, is due to the differences in the physical character of the water-bearing deposits from place to place. Some of the difference may be due to mode of construction of wells and differences in depth; but generally the production for any given well is roughly proportional to the quantity of coarse well-sorted material penetrated beneath the water table, and any properly constructed well in the centralvalley alluvium drilled to a sufficient depth beneath the water table can be expected to yield moderate to large quantities of water. Shallow wells, 100 feet or less in depth, that penetrate poorly sorted or clayey material may yield only a few gallons per minute, whereas deep wells, such as 26/39-30F that penetrate much coarse well-sorted material may yield as much as $2,000 \mathrm{gpm}$ Permeability of the younger alluvium as determined in several places is discussed in the section on pumping tests. 
Younger Lacustrine Deposits

Definition and age.--Younger lacustrine deposits include lenticular beds of silt and silty clay that crop out in Salt Wells Valley, are penetrated in wells in Indian Wells Valley, form conspicuous castlelike deposits of calcareous tufa in both Indian Wells Valley and Salt Wells Valley, and form one outcrop of cemented waterworn gravel at 2,240 feet in Indian Wells Valley. These deposits all occur at an altitude of 2,240 feet or less. Because of their altitude these deposits are presumed to be associated with the 2,256-foot stage of Lake Searles and Lake China of late Pleistocene age.

Distribution and omigin.--In the central part of Salt Wells Valley, marginal to the playa, a horizontally bedded section of white to gray finegrained silt and clay crops out. The thickness of these deposits in this area has not been measured or penetrated by wells, but where exposed they are over 50 to 75 feet thick. This material probably was deposited by a shallow extension of Lake Searles.

Similar younger lacustrine deposits are also penetrated at shallow depth by wells in the central part of Indian Wells Valley beneath most of the surface mapped as windblown sand and interdune playas.

Along the 2,240-foot land-surface contour in Salt Wells Valley there are conspicuous deposits of calcareous tufa which form crags, castlelike structures, and towers. The outcrop of these structures varies greatly in size. In some places they are less than 1 foot in height and area, and in others they are 20 feet high and cover an area of several hundred square feet. They may be semicontinuous for considerable distances. Similar tufa structures are almost completely absent in Indian Wells Valley, except in a limited area at an altitude of about 2,240 feet in the vicinity of the NW corner of sec. 34, T. $24 \mathrm{~S}$., R. $39 \mathrm{E}$. The castlelike calcareous deposits of tufa are similar to deposits in other areas, described by Twenhofel (1932, p. 326) who attributed their formation to evaporation of saline water on algae, or similar growths, along the shoreline of a salt lake or playa.

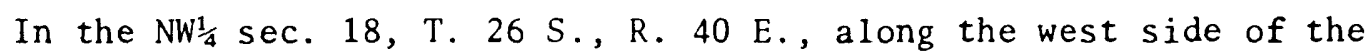
weapons center access road at an altitude of 2,240 feet there is one small outcrop, less than 200 feet long, of waterworn gravel containing pebbles up to 2 inches in diameter. This outcrop occurs along a cut shoreline terrace and is correlated with the tufa.

During Pleistocene time, Lake Searles and Lake China were a single body of water with a surface altitude of 2,256 feet, as determined by Blackwelder $(1933,1941)$. The deposits that occur at an altitude of 2,256 feet or less in both Indian Wells and Salt Wells Valleys are associated with this stage of Lakes Searles and China.

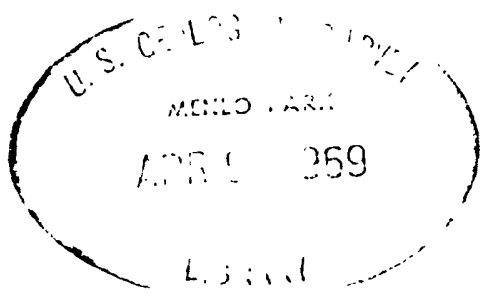


Lithology and water-bearing properties.--The younger lacustrine deposits are composed of lenses of clay and micaceous silt and occasional beds of sand or sandy silt. Typical logs of wells that penetrate younger lacustrine deposits at shallow depth are for wells 25/40-27E1, 25/41-19L1, 26/41-7E1, and 25/40-25P1 (Moyle, 1963).

Most of the younger lacustrine deposits as mapped are of limited extent and thickness and generally occur above the water table. Locally where these deposits occur at depth beneath the playa deposits they may yield small quantities of water to wells; however, because they are in an area of saline water, the quality is unusable for most purposes.

Playa Deposits

Definition and age.--The playa deposits in Indian Wells Valley are composed of gray silt, yellow, green, and blue plastic clay, and occasional sand lenses. This unit is limited to fine-grained deposits beneath the surfaces of China, Mirror, Satellite, and Coso Lakes and several unnamed dry lakes in Indian Wells and Salt Wells Valleys. The playa or dry-lake areas are occasionally covered by water, but most of the time they are dry or only moist and may be covered with alkali or saline crusts. The playa deposits interfinger along their margins with the central-valley alluvium; locally they are covered by windblown sand. The thickness of the Holocene playa deposits is not known, but in the central part of China Lake the thickness is probably several tens of feet. With available data it was not possible to distinguish the playa deposits from the underlying younger and older lacustrine deposits.

The age of the uppermost playa deposits is Holocene. Because no distinct. lithologic marker bed has been found, the depth to which the playa deposits of Holocene age extend is not known. However, playas have probably existed in Indian Wells Valley more or less continuously from the late pleistocene through the Holocene, and as seen today the playas are in a final stage of desiccation. Therefore, at moderate depth the playa deposits grade into and are indistinguishable from the clay and silt of the underlying younger and older lacustrine deposits. 
Distribution and origin.--The playas of Indian Wells Valley are along the esst side of the valley ( $\mathrm{fig}$. 2). The main playa is China Lake. The next largest playa (unnamed) is about 2 miles north of China Lake. Two other playas in Indian We1ls Valley are Mirror Lake and Satellite Lake. In addition to these, there are also numerous small playas west of China Lake. Most of these smaller playas are only a few hundred feet across and occur between areas of windblown sand and will be discussed in the section on windblown sand. There is also a dry playa in the lowest part of Coso Basin. This undrained depression, Coso Lake, was dammed along the southeast side of the valley by the encroachment of the large coalescing alluvial fans southeast of Coso Basin. The material that forms the Holocene playa deposits on the floor of Coso Lake has been largely derived from the alluvial deposits to the north and to a smaller degree from the other surrounding deposits during cloudbursts and sheet floods.

Another playa is along the central drainage line of Salt Wells Valley. Here also the playa deposits have been derived from the surrounding deposits during cloudbursts and sheet flooding.

Most of the fine-grained materials that compose the playa deposits of China Lake and the unnamed lake to the north have been washed in from the surrounding areas following occasional cloudbursts and flooding. Also, some of the sand in these deposits has undoubtedly been blown in by the wind. These materials were deposited in successive layers at the bottom of the lake. Deposition still occurs during periods of occasional flooding. However, wind deflation, as described by Blackwelder (1931b), occurs and locally may exceed the rate of deposition.

The playa deposits of Satellite and Mirror Lakes, which lie in the undrained depressions in the younger alluvium above the 2,260-foot shoreline of Lake China, were probably derived locally from the surrounding alluvial areas during times of cloudburst and flooding.

Lithology and water-bearing properties.--The playa deposits are highly micaceous and generally of silt size or larger. Samples collected during drilling of test holes consist almost wholly of silt, sandy silt, and fine sand, although true plastic clays occasionally were penetrated. Typical logs of wells drilled into the playa deposits are given in Moyle (1963) for wells $25 / 40-25 \mathrm{P} 1,25 / 40-35 \mathrm{P} 1,26 / 40-26 \mathrm{Bl}$, and $26 / 40-26 \mathrm{R} 1$.

Water occurs in playa deposits beneath China Lake and the unnamed playa to the north. However, the materials are generally of low permeability, so the quantity of water available is only a few gallons per minute. Also, shallow water beneath the two lakes is highly saline and unfit for most uses. Water beneath the surface of Coso Lake, Mirror Lake, and Satellite Lake occurs in deposits that underlie the Holocene material, and yields of wells drilled in these areas do not indicate the water-bearing properties of the Holocene deposits. 
Windblown Sand and Interdune Playa Deposits

In the area surrounding China Lake and the unnamed playa to the north, windblown sand has been deposited as dunes with hundreds of small interdune playa deposits that range in area from a few hundred square feet to several acres. These dunes commonly occur as ridges transverse to the direction of the prevailing winds. In this area the depth to water, under natural conditions, is less than 8 or 10 feet, and the fine-grained material has been within the capillary fringe of the water table and has been moist at all times since the desiccation of Lake China. This moist ground covered with a growth of saltgrass or pickleweed holds back windblown sand and causes the formation of sand dunes and sand ridges transverse to the prevailing wind.

The height or thickness of these sand dunes and ridges ranges from less than 1 foot to about 10 feet for the largest dunes. Over areas several mile square the dunes may be low, often less than 1 or 2 feet high. One such are of low dunes with interdune playas is several miles north of Armitage Field; along the range access road northwest of China Lake larger dunes are common.

Because these dunes interrupt any integrated drainage, many small inter dune playa deposits have formed in undrained hollows during times of cloudbu and runoff. Based on an examination of aerial photographs and a check of several selected typical areas, it seems that the interdune playa deposits occupy about 10 percent of the total area in this unit. These playas are no necessarily part of the once extensive Lake China playa, but are small playa deposits of Holocene age that interfinger with the windblown sand along thei margins and probably lie unconformably on the older Lake China playa deposit

These sand dunes and interdune playa deposits are partly below the wate table and wells in these deposits usually yield small quantities of water of poor quality. Wells drilled through these deposits probably would penetrate playa deposits and younger lacustrine deposits at shallow depth and older lacustrine deposits at greater depth. 
The youngest and most active deposit in Indian Wells Valley is windblown sand. This deposit occurs on all other formations and can be observed to form on any windy day. Prevailing winds from the west pick up large quantities of sand, silt, and clay derived from the alluvium on the west side of the valley and carry it east. The coarser materials are deposited on other formations as a well-sorted sand veneer locally blown into dunes. Also, much of the finer materials is blown out of the basin.

The windblown sand usually occurs as a veneer that generally masks the underlying deposits. The maximum thickness of the veneer is not known, but, in general, it ranges from 0 to a maximum of about 25 feet. Under natural conditions the depth to water in or beneath this unit is greater than 10 feet.

Along the north side of the valley sand covers part of the volcanic rocks and part of the older lacustrine deposits; along the east side of the valley it covers basement complex, fan deposits, and probably playa deposits; along the west side of the valley it covers younger alluvium and probably playa deposits.

Windblown sand also fills the old outlet of China Lake to a depth of 41 feet, as indicated by the logs of test we1ls $26 / 41-7 G 1$ and $7 G 2$. Well $7 G 1$ penetrated coarse windblown sand for its entire depth of 37 feet and wel1 $7 \mathrm{G} 2$ penetrated coarse windblown sand to a depth of 41 feet and bedrock below 41 feet. No water-laid material is known to occur in this channel.

These sand deposits are not usually considered a source of ground water because they generally occur above the water table, and the water-yielding potential of any proposed well to be drilled in this area should be evaluated in terms of the underlying deposits. 
Geologic Structure

The area considered in the treatment of geologic structure comprises Indian Wells Valley, part of Rose Valley and Coso Basin, and Salt Wells Valley which lies to the southeast of Indian Wells Valley. The area is in the southwest part of the Great Basin as described by Fenneman (1931) and in the westcentral part of the Mojave Desert region as described by Reed (1933). In late Tertiary time the drainage systems of these four basins probably were interconnected, but subsequent faulting, outpourings of lava, and the deposition of lacustrine deposits has separated the area into more-or-less disconnected basins.

Faults

Indian Wells Valley and parts of Rose Valley, Coso Basin, and Salt Wells Valley comprise a single down-faulted block formed by three and possibly four major fault zones. These major fault zones, shown in figure 2, are the Sierra Nevada on the west, the Argus on the east, the Garlock on the south, and probably the Wilson Canyon on the northeast. Locally, complex faulting occurs in all the bordering ranges, but these faults, though related to the structure of the area, have not determined the basic structure of the valley.

The Sierra Nevada fault zone lies along the west side of Indian Wells Valley and along the east side of the Sierra Nevada. The vertical movement on this fault zone has uplifted the Sierra Nevada and downdropped the Indian Wells Valley. The trace of this zone, though largely concealed beneath alluvial fans, extends northward beyond Indian Wells Valley. Based on the work of Knopf (1918) and Reed (1933) to the north in the Owens Valley area, the total vertical displacement on this zone has been several thous and feet, occurring since the close of the Miocene Epoch with the last major movement occurring in middle Pleistocene time.

The Argus fault zone lies along the west side of the Argus Range. The vertical movement on this fault zone has uplifted the Argus Range and downdropped Indian Wells Valley. At the north end, the fault zone seems to be terminated or offset by the Wilson Canyon fault zone. The Argus fault probably extends north between the Coso and Argus Ranges. The steep western scarp of the Argus Range and the depth to bedrock as shown by the log of well 26/40-22P1 indicates that the total vertical displacement along this fault zone may be several thousand feet. The southern extent of the Argus fault zone is not known, but the zone seems to split--one fault exposed at the divide between Indian Wells and Salt WeIls Valleys extends to the southeast and is concealed beneath the alluvium of Salt Wells Valley and the other seems to trend southerly across the outcrop of older lacustrine deposits. Th trace of this fault in the El Paso Mountains to the south cannot be determine Considerable faulting occurs along the north side of the El Paso Mountains, a part of which may be related to the Argus fault zone and part of which may be related to the Garlock fault zone. 
The Garlock fault zone on the south flank of the El Paso Mountains marks southern margin of the area considered. This fault zone branches from the Andreas rift to the southwest and has a northeasterly trend as far as the south end of Death Valley. Hulin (1925) indicates that the movement along the Garlock fault zone has generally been horizontal, with an offset as great as 6.miles. Hill and Dibblee (1953) suggest that probably 2,000 feet of displacement has been recent movement.

The Wilson Canyon fault zone is a group of northwest-trending faults in the Argus Range that form a distinct graben. If the Wilson Canyon fault zone were projected northwest to Little Lake, it would lie along a line of volcanic vents that were the source of the unnamed volcanic rocks in that area.

Although direct evidence of the projection is lacking, it is likely that the wilson Canyon fault zone extended to the Little Lake area and that the volcanic vents occurred along the zone of weakness formed by the fault zone.

Indian Wells Valley has been depressed by considerable movement along these major fault zones. From well data one can determine the approximate magnitude of this depression. Well 26/40-22P1, about a quarter of a mile east of the weapons center main gate, is the only well in the central part of the valley drilled to bedrock. This well, drilled by the weapons center as part of the test-well drilling program, penetrated bedrock at 1,350 feet. All other wells in the central part of Indian Wells Valley, some of which were drilled to 800 feet, are reported to bottom in unconsolidated deposits. Thus, the maximum depth to the consolidated rock floor of Indian Wells Valley along the base of the Argus Range is at least 1,350 feet below land surface. Elsewhere the depth to consolidated rock may be approximately the same or in places greater. The height of the Argus Range above the valley floor is 4,000 feet. Thus, the total displacement along the Argus fault zone may be greater than 5,000 feet.

Minor faulting has occurred in the continental deposits southwest of U.S. Highway 395 . One fault in the north half of T. $28 \mathrm{~S} .$, R. $39 \mathrm{E}$., exposed more-or-less continuously for about 3 miles, strikes $N .40^{\circ} \mathrm{E}$. and has a dip that ranges from $64^{\circ}$ to $85^{\circ} \mathrm{NW}$. Locally this fault is concealed beneath the Black Mountain Basalt. Two other minor faults are mapped in the north part of T. 29 S., R. $38 \mathrm{E}$.

One of the most prominent faults in Coso Basin occurs in the alluvium at Coso Hot Springs and seems to be the rift along which the hot water rises that forms the Coso Hot Springs.

One probable northwest-trending fault is inferred beneath the fan deposits about 3 miles south of Inyokem. There is no surface indication of this fault, but its existence is inferred from a great increase in the ground-water gradient or disparity of water levels between well $27 / 38-1 \mathrm{Ml}$ and the wells around Inyokern and well 27/39-7RI (figs. 2 and 6). 
Relation of Dikes to Structure

Numerous dark-colored basic dikes cut the basement complex of the Argus Range north of Salt Wells Valley and south of the Wilson Canyon fault zone. These dikes range in width from approximately 10 to $30 \mathrm{feet}$, are generally vertical, strike approximately N. $50^{\circ} \mathrm{W}$., and may be exposed continuously for distances greater than a mile. The trend of these dikes indicates the internal structure of the fault block in which they occur. North of the Wilson Canyon fault zone dikes of this type are less common and generally strike about N. $20^{\circ} \mathrm{W}$. South of Salt Wells Valley dikes of this type are very rare.

South of Ridgecrest both dark-colored basic dikes and light-colored acid dikes cut the basement complex. These dikes are of two sets and are associated with numerous small faults. The trend of these dikes is not persistent and only indicates geologic structure for areas a few miles square.

In the Sierra Nevada the basement complex is cut by dikes of dark-colored granodiorite which in turn are cut by dikes of pink granite. These dikes do not seem to be persistent in direction or altitude; they have not been shown on the geologic map.

\section{Folding and Other Structures}

There has been much complex folding of the rocks of the basement complex. However, in the area of this investigation the folding of the basement complex: is not closely associated with the occurrence of ground water and therefore was not mapped.

Except for minor variations the continental deposits strike about N. $45^{\circ}$ I and dip from $5^{\circ}$ to $20^{\circ} \mathrm{NW}$. Where these deposits occur on the Saltdale quadrangle the structure has been mapped in detail by Dibblee (1952); elsewhere] it has been mapped by the Geological Survey.

There has been some deformation of the older lacustrine deposits at the north end of Indian Wells Valley. South of Coso Lake in the central part of the older lacustrine deposits the beds are generally flat lying, but along the north edge of the exposure the beds strike N. $58^{\circ}$ to $80^{\circ} \mathrm{W}$. and dip $8^{\circ} \mathrm{N}$. On the south edge the beds strike $\mathrm{N} .66^{\circ} \mathrm{E}$. and dip $2^{\circ}$ to $3^{\circ} \mathrm{S}$. On the east flank the beds generally strike about $\mathrm{N}$. $5^{\circ} \mathrm{W}$. and dip $17^{\circ}$ to $20^{\circ} \mathrm{E}$., but some beds strike N. $62^{\circ}$ to $75^{\circ} \mathrm{E}$. and dip $14^{\circ} \mathrm{S}$. These variations in strike may be due to minor faulting, but the general pattern of strikes and dips suggests a gentle southeast-plunging anticline. 
Over much of their areal extent the older lacustrine deposits are overHin by extrusive basalt. A prominent window of older lacustrine deposits is xposed in the northeast part of T. $24 \mathrm{~S} ., \mathrm{R}, 38 \mathrm{E}$. Here the older lacustrine leposits were observed to strike approximately N. $45^{\circ} \mathrm{W}$. and dip $13^{\circ}$ to $22^{\circ} \mathrm{SW}$. Bower, these steep dips may be caused by nearby volcanic activity.

The Black Mountain Basalt in the El Paso Mountains generally has about the same strike but a lower dip than the underlying Ricardo and Goler Formations. The unnamed volcanic rocks as mapped in Rose Valley, Coso Basin, and the north end of Indian Wells Valley dip away from the volcanic cones or rents from which they were extruded. The flows generally extend over or beneath the several alluviums of the surrounding area. The unnamed volcanic rocks do not seem to be folded or faulted and the dips are probably the initial dips of the flows as they were extruded.

\section{Geologic History}

The Paleozoic and Mesozoic history of Indian Wells Valley is fragmentary. In general, evidence for deciphering the detail of events during these periods is not available, except as indicated by work in nearby regions. Also, the Paleozoic and Mesozoic history of Indian Wells Valley does not bear a direct relation to the present ground-water bodies and existing hydrologic problems. Therefore, the early history of the area is summarized only briefly in the following section.

\section{Regional History}

In Indian Wells Valley the oldest deposits exposed are isolated remnants and roof pendants of metamorphosed sedimentary and igneous rocks that are Paleozoic in age. These rocks are part of the basement complex and indicate that the Indian Wells Valley area was the site of marine deposition and igneous activity during part of the Paleozoic Era.

Insofar as can be determined, the area of Indian Wells Valley was above sea level during all the Mesozoic Era. During the Jurassic and early part of the Cretaceous Periods, diastrophism and mountain building of the Sierra Nevada region was of low intensity and the region was reduced to one of low relief with a humid climate and probably dense forests. Near the end of the Cretaceous Period there were intrusions of great igneous masses and crustal movement along the Sierra Nevada fault zone, and it was during this period that the now extensively exposed granodiorite and granite of the basement complex were injected into the older Paleozoic rocks. More complete accounts from which this summary has been drawn are presented principally by Hulin (1925), Reed (1933), Blackwelder (1948), and Dibblee (1952).

The Cenozoic history of the area is directly related to the occurrence, source, and movement of ground water in Indian Wells Valley and is covered more fully in the following section. 
During the early part of the Tertiary Period there was almost complete cessation of crustal disturbances, and erosion once again reduced the region to an area of low relief. However, during the later part of the Tertiary Period, beginning as early as the Miocene Epoch, renewed crustal movements along the major fault zones occurred and began to form the general outlines of Indian Wells Valley. Deposition of fluviatile, lacustrine, and volcanic deposits in this basin during the Miocene and Pliocene Epochs are indicated by the outcrops of Goler and Ricardo Formations. Local volcanic activity also occurred during the Miocene and Pliocene Epochs and was probably climaxed early in the Pleistocene Epoch by the extrusion of the Black Mountain Basalt.

Beginning in the Pleistocene, or possibly late in the Pliocene Epoch, and continuing into the Holocene Epoch, Indian Wells Valley, in general as delineated by its present boundaries, has continuously received detritus from the surrounding mountains and highlands. The study of these pleistocene and Holocene deposits indicate an alternating deposition of fluviatile and lacustrine deposits which at times has been interrupted by volcanic flows, faulting, and changes in climate and drainage pattern.

Though the evidence is not conclusive, cautious speculation based on a study of the physiography and geology of Indian Wells Valley indicates a sequence of six major events. These events are described in the following paragraphs.

1. Early in the Pleistocene, or possibly beginning in late Pliocene time, the lower part of the older alluvium was deposited. During this time Indian Wells Valley was not necessarily a closed basin, but probably was part of a larger integrated drainage system that flowed south through the area.

2. During the middle Pleistocene orogeny, a time during which compression, folding, and shearing formed many of the closed desert basins in souther California, Indian Wells Valley was generally outlined in its present form.

3. In the first pluvial, or time of heavy precipitation, which may correspond with the Sherwin or McGee Glaciations, a large lake extended over much of Indian Wells Valley in which the older lacustrine deposits accumulate There was also continued deposition of older alluvium along the margins and locally in the interior of Indian Wells Valley. The valley may have existed as a closed basin during part of the first pluvial, but there was also probably some overflow and excavation of a channel to Salt Wells Valley through an outlet, which is now poorly preserved, about 4 miles northeast of the Rademacher Hills. 
In interpluvial time of relative aridity, the lake of the first pluvial dried up and deposition of younger alluvium began. Near the close of this time the unnamed volcanic rocks at the north end of the valley were extruded and covered the older lacustrine deposits and older alluvium, and were interbedded with the younger alluvium. Renewed faulting along the southwest side of the Argus Range modified the drainage pattern, but the drainage basin maintained the same general form.

5. In the second pluvial, or second period of heavy precipitation, which according to Blackwelder (1931a) corresponds with the Tahoe Glaciation, Lake China and Lake Searles formed a larger interconnected body of water that discharged into Panamint Valley as shown by Hubbs and Miller (1948, map 1). The surface of this body of water was about 640 feet above the present salt plain of Searles Lake or at an altitude of 2,256 feet. During this pluvial the younger lacustrine deposits were formed, and there was also continued deposition of younger alluvium.

Blackwelder (1933, 1941) and Hubbs and Miller (1948) indicate that the 2,256-foot stage of Lake Searles and Lake China is probably correlated with the Tahoe Glaciation. In this connection it is pointed out that the 2,256-foot shoreline in Indian Wells Valley cuts across the older lacustrine deposits here considered to be Sherwin or McGee in age. Because this shoreline must be younger than the deposits it cuts, a post Sherwin or McGee age for the shoreline seems to be justified.

6. The end of the second pluvial was accompanied by the gradual desiccation of Lakes Searles and China. During desiccation of these lakes, flow between them cut a channel through a low saddle in the Argus Range from Indian Wells to Salt Wells Valley. As desiccation progressed these two lakes eventually became separated with only intermittent flow occurring through a channel between them, and eventually Lake China completely dried up. The once-connecting channel, in sec. 7, T. 26 S., R. 41 E., is now partially filled with windblown sand. Since then ephemeral China Lake has occupied the area now underlain by the playa deposits of Holocene age.

The contact between younger lacustrine deposits and playa deposits could not be determined, but for the purposes of this report the base of the playa deposits is considered to be the base of the first deposits laid down in ephemeral China Lake after the complete desiccation of Lake China. Deposition of playa deposits and younger alluvium has continued at a reduced rate to the present. 
GROUND WATER

The unconsolidated deposits in Indian Wells Valley are those from whic the Naval Weapons Center, Inyokern and Ridgecrest, the ranches, and all oth ground-water users draw their water. All the ground water in Indian Wells Valley has its source as precipitation that falls within the drainage areas Indian Wells Valley, Rose Valley, and Coso Basin. This water does not move a stream or channel, but percolates through the pore spaces in the waterbearing formations from areas of replenishment toward points of discharge. There is no evidence of any underground source or movement of water from ou side the drainage area considered. A very small quantity of ground-water underflow out of the valley to Salt Wells valley occurs through the narrow channel in sec. $7, T .26 \mathrm{~S} ., \mathrm{R} .41 \mathrm{E}$., which is the most recent outlet of Pleistocene Lake China (figs. 2 and 3 , section $B-B^{\prime}$ ).

In Indian Wells Valley, as in any ground-water basin, all the pore spa in all the deposits beneath the water table are saturated or full of water. However, all the rocks and deposits do not yield water to wells with the sas facility. The consolidated rocks and the volcanic rocks around the margins and at depth beneath the valley are generally of low permeability and do no yield water to wells except for minor quantities in fractures.

Not all the unconsolidated deposits yield water to wells in the same quantity. For example, loose rounded well-sorted gravel or sand yields wat more freely to wells than does clay, silt, cemented sand, cemented gravel, compacted poorly sorted angular material. The yields of wells are roughly proportional to the permeability of the water-bearing deposits.

The total quantity of ground water available for pumpage from a ground water basin is dependent on the annual recharge, the natural discharge, and ground-water storage capacity. These and other general principles of occurrence of ground water have been discussed by Meinzer (1923a, b) and ar not discussed in detail in this report, but they form the basis for the evaluation of ground-water conditions of Indian Wells Valley.

\section{Occurrence of Ground Water}

In Indian Wells Valley by 1954 more than 350 wells had been drilled in the unconsolidated deposits from which virtually all the water used in the valley has been drawn. Data from these wells show that the water in these deposits is continuous beneath the water table and may be tapped by wells drilled anywhere in them, except close to the valley margins where the unconsolidated rocks may be penetrated above the water table. In the following discussion ground water in the unconsolidated deposits is discussed according to its occurrence in a main water body, a shallow wate body, and minor water bodies. 
Main Water Body

The main water body (fig. 5) occupies the central part of the valley--the uproximate boundaries are the Inyo County line on the north, an east-west line approximately $2 \frac{1}{2}$ miles south of the weapons center boundary on the south, the Argus fault zone on the east, the Sierra Nevada fault zone on the west, and a probable ground-water barrier about 2 miles south of Inyokern on the southwest (fig. 5). The containing formations include the younger alluvium and fan deposits, older alluvium, and younger and older lacustrine deposits. The bottom of the water body is considered to be the base of the older alluvium. The thickness is dependent upon the depth to water below land surface and the depth to non-water-bearing rocks. The saturated thickness at vell 26/40-22Pl is about 1,275 feet, and the thickness is probably at least 1,000 feet beneath most of the central valley area.

Most wells penetrate only from 50 to 400 feet into the main water body, and they disclose differences in head of only a few feet within that range of penetration. With respect to land surface, the head or water level in wells that tap the main water body ranges from a few feet above on the east side of the valley in the vicinity of China Lake to 401 feet below in well 27/39-16Fl on the south side near the El Paso Mountains. However, the depth to water in most of the wells in the valley is between 100 and 200 feet.

Most of the main water body beneath the area underlain by the younger alluvium is unconfined; however, in the eastern part of the valley beneath China Lake and the area covered by windblown sand and interdune playa deposits, the main water body is confined by impermeable clay of the younger and older lacustrine deposits and the playa deposits. The area of confined water is north of a somewhat irregular and ill-defined line (fig. 2) extending from the weapons center main gate to Sandquist Spa and east of a line extending north from the Spa. South and west of this line the water body is largely unconfined.

Most of the used wells in the area draw water from the unconfined part of the main water body from depths less than 400 feet below land surface. These wells usually penetrate lenses of gravel or clay and gravel, and the yields of the wells, which vary roughly in proportion to the amount of gravel penetrated, range from almost nothing to more than 2,000 gpm. There are no wells of large yield in the central part of the confined water area. Of the wells that have been drilled there, only a few ever have been used for stock watering, principally because of the poor quality of the water.

Well 26/40-22Pl penetrated confined water in the older alluvium beneath the older lacustrine deposits. An electric log of this well indicated permeable zones of sand from 530 to 850 feet. This well, only partially developed for the purpose of obtaining a water sample for chemical analysis, was pumped at the rate of $200 \mathrm{gpm}$ with a drawdown of 246 feet. A properly constructed and developed gravel-packed well of large diameter in this same zone probably would yield several times this amount of water with less drawdown. 
Water in the unconfined part of the main water body is generally of good quality, but locally, in the area southeast of Ridgecrest, some unconfined zones in the main water body are brackish to highly saline. In the area of confinement, the water is generally of poor quality; and in the deepest part, penetrated only by well 26/40-22P1 below 850 feet, the water, as inferred from an electric log, is extremely saline.

The temperature of ground water normally fluctuates very little during the course of a year, the fluctuation being greatest in shallow wells and least in deep wells. The temperature of water in wells tapping deposits 50 to 150 feet below land surface usually is constant and approximately equal to the mean annual temperature of the region. In the main water body in Indian Wells Valley this temperature is generally $68^{\circ}$ to $70^{\circ} \mathrm{F}$. In wells 400 to 452 feet deep the temperature is $76^{\circ}$ to $83^{\circ} \mathrm{F}$, which is above the normal geothermal gradient of $1^{\circ}$ to $2^{\circ} \mathrm{F}$ for approximately each 100 feet of depth.

\section{Shallow Water Body}

The shallow water body lies above the confined part of the main water body principally beneath China Lake and vicinity (fig. 6). The base of the shallow water body is poorly defined, but roughly between 50 and 150 feet below land surface. Locally, appreciable differences in head exist between shallow wells and deeper wells. Wells 50 to 150 feet deep drilled into the shallow water body generally penetrate clay of very low permeability with occasional lenses of sand or sand and clay, yield water in very small quantities, and have a lower head than nearby deeper wells that are drilled into the confined part of the main water body. This differential in head is shown by four pairs of shallow and deeper wells: 24/40-32H1 (111 feet deep) and 33El (161 feet deep), 25/40-11K2 (5 feet deep) and $11 \mathrm{~K} 1$ ( 62 feet deep), 25/40-12M2 (5 feet deep) and $12 \mathrm{M1}$ (59 feet deep), and 26/40-1A3 (18.5 feet deep) and $1 \mathrm{~A} 2$ (198 feet deep). In each of these pairs the deeper well flows whereas the depth to water in the shallow well is from 3 to 6 feet below land surface.

In this area water in deeper wells is in poor hydraulic continuity with water of lower head at shallow depth, and the rate at which water moves upward: from the main water body to the shallow water body is very slow because they are separated by several tens of feet of poorly permeable beds of clay and silt of the lacustrine and playa deposits. Consequently, the shallow water body in this area is considered as semiperched and partially separated from the main water body. 
North of Intermediate along the west margin of the confined water, deep is of intermediate depth have a lower head than nearby shallow wells. Here X page has lowered the regional water level in the deep wells more than 10 feet since 1920. Deep wells in this area, such as 26/39-11E1, 26/40-17N1, and 26/40-18N1, ranging in depth from 158 to 250 feet, which penetrate pormeable zones, indicate this reduced head; whereas shallow wells, such as 26/39-2N1, 26/39-13P1, 26/40-18El, and 26/40-20G1, ranging in depth from 97. to 158 feet, which are probably drilled in less permeable material, indicate a shallow semiperched water body that is probably in hydraulic continuity with shallow water farther east.

is:

.6. North of Intermediate the deposits that contain the semiperched water body have a very low permeability, and downward drainage into the underlying main water body contained in more permeable deposits is very slow. The yield of wells in this semiperched body is also very low, only a few gallons per week.

\section{Minor Water Bodies}

Several water bodies, which are separate from but discharge across barriers or cascade over consolidated rock to the main water body, occur in the unconsolidated deposits around the margins of Indian Wells Valley. The largest of these is beneath the extensive upland valley area southwest of Inyokern and is separated from the main water body by a postulated groundwater barrier (figs. 2 and 6 ). In this area the ground water is contained in the older formations and deposits, and well yields are low.

Other minor bodies are contained in the fan deposits perched on the rock pediments, principally west of the Sierra Nevada fault zone and east of the Argus fault zone. The wells that penetrate these water bodies have yields of only a few gallons per minute, sufficient only for limited domestic and stock needs. 
Source and Movement of Ground Water

Ground water moves from a source or place of high head toward an area of discharge or lower head. The head of a ground-water body is shown by the altitudes of the water levels in wells; hence, water-level contours or lines connecting points of equal head on the water body indicate the configuration of its surface in the same manner that contours drawn on points of equal altitude of land surface indicate the configuration of the ground. Groundwater movement is perpendicular to the contour lines and toward points of lower head.

Figures 5 and 6 show water-level contours for the ground-water bodies in Indian Wells Valley. Figure 5 shows three sets of water-level contours on the main water body--figure 5A is for 1921, figure 5B is for 1946, figure 5C is for 1954. Figure 6 shows water-level contours for 1954 drawn on the shallow water body.

The contours in figures 5 and 6 indicate that the main source of ground water in Indian Wells Valley is from the Sierra Nevada with minor quantities from the other hills and mountains surrounding the valley. Surface flow from Rose Valley into Indian Wells Valley occurs at Little Lake. Underflow from Rose Valley into Indian Wells Valley is also indicated by springs at Little Lake and by a steep ground-water gradient between we11s $24 / 38-28 Q 1$ and 24/38-35EI.

In the area of confinement (fig. 6) contours drawn on the shallow water body show that the water moves toward the central part of China Lake from all sides, indicating a ground-water depression caused by discharge. The study of the hydrology indicates that the discharge is evaporation from the playa surface and transpiration by plants whose roots draw water from the shallow water body. In the same area water levels in deep wells, tapping the confined water in the main water body, generally rise above land surface. The contours (fig. 5) drawn on the main water body show that the deep water moves eastward, and that part of the water not discharged upward to the shallow water body moves toward the narrow channel in sec. 7, T. $26 \mathrm{~S} ., \mathrm{R} .41 \mathrm{E}$., where it discharges as ground-water outflow to Salt Wells Valley. 
Fluctuations of Water Level

All known measurements of water levels and other well data for Indian Ils Valley have been collected and tabulated and subsequently published byle, 1963). Included are measurements of water levels by Lee (1913), lompson (1929), Whistler (1923), Wilcox, Hatcher, and Blair (1951), the Navy, Il drillers, and other interested persons. During this investigation the ological Survey also made more than 1,200 measurements of water levels in re than 200 wells, including periodic measurements in 97 weils, and operated ontinuous water-level recorders for periods of several weeks to 2 years in Is wells.

Long-Term Fluctuations

Records of water-1evel fluctuations in selected wells in Indian Wells talley are shown as hydrographs in figures 7,8 , and 9 . The graphs indicate hat the levels in wells 25/39-2E1, 25/39-28P1, 26/39-10N1, and 26/40-15E 1 in the central part of the valley are virtually unchanged since 1912 or 1921 . the hydrographs for wells 26/39-23El, 26/39-25D1, 26/40-22N1, and 27/40-1MI Wear areas of present ground-water development indicate that in the vicinity of Intermediate the regional water level may have declined between 7 and 25 feet since 1912 or 1921.

A comparison of the water-level contours for 1921 (fig. 5A) and 1954 (fig. 5C) indicates that the regional water level in the vicinity of Ridgecrest may have undergone an average net decline of as much as 15 feet. During periods of heavy pumping in the summer, the net decline was greater. 1 The scant records of water levels in the vicinity of Inyokern suggest that, except for a decline of possibly 5 feet, levels in 1954 are nearly the same as those in 1912 or 1921. 

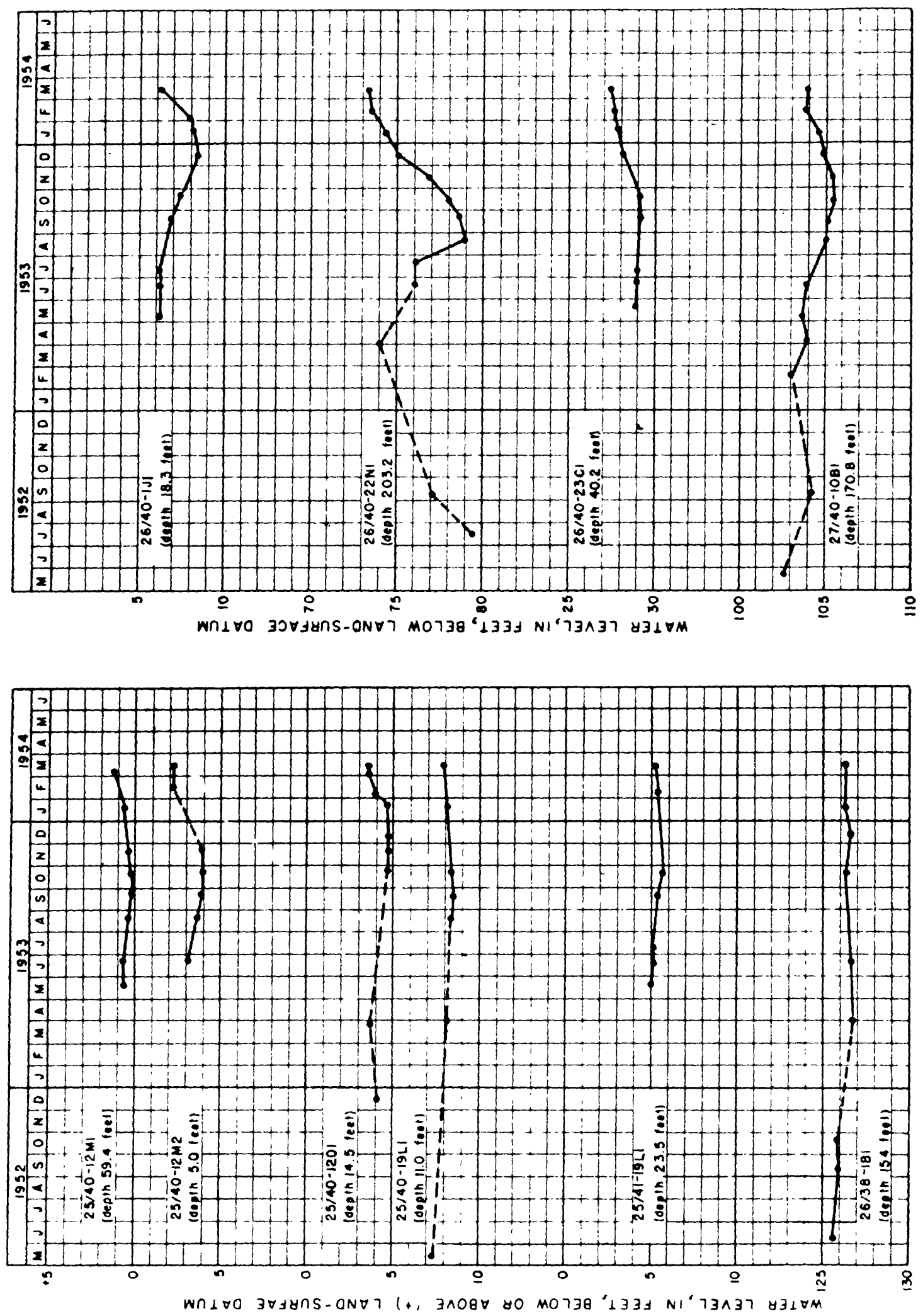


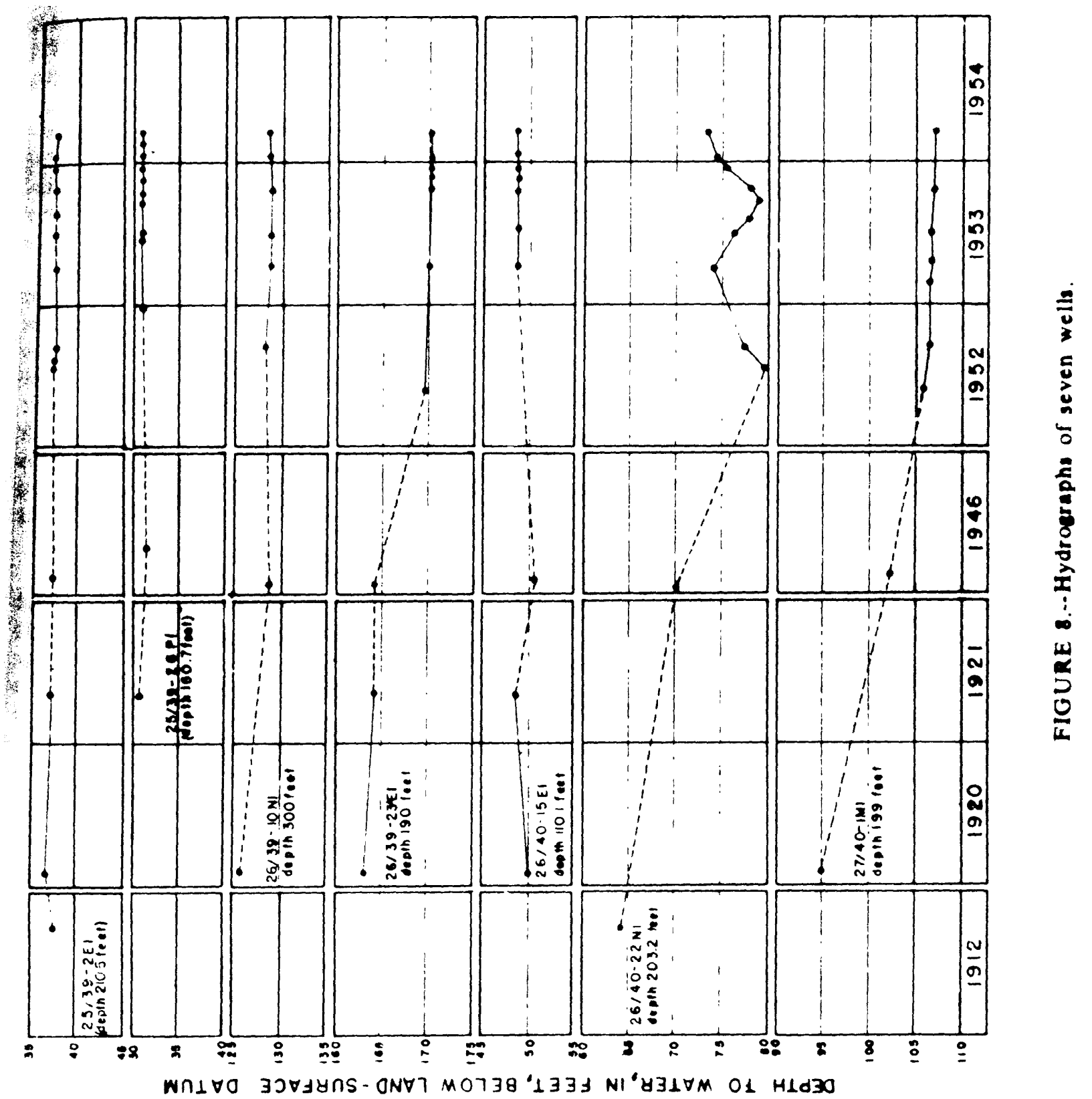




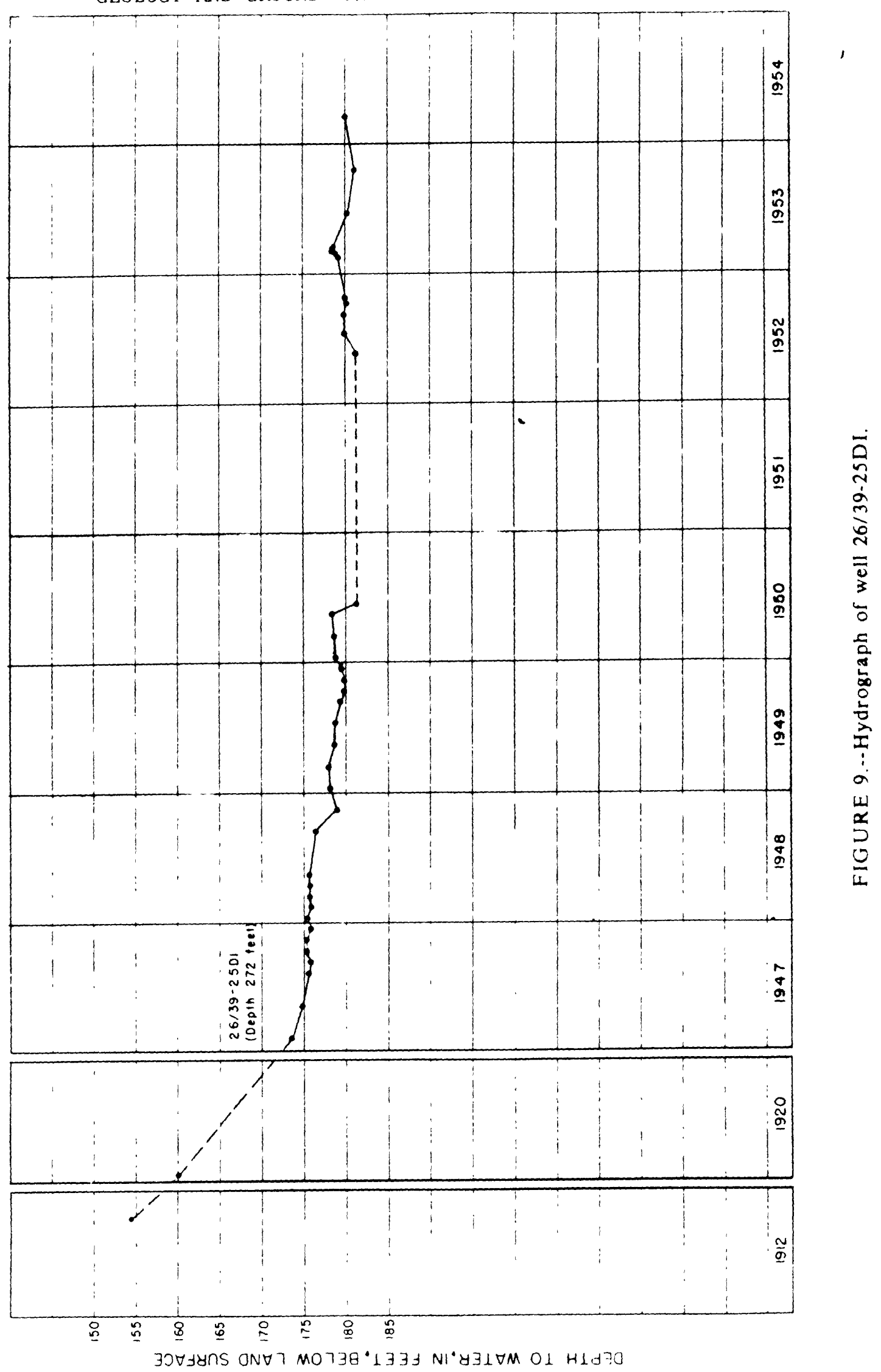


Short-Term Fluctuations

The two types of short-term fluctuations of water levels commonly tserved in wells in Indian Wells Valley are daily and seasonal fluctuations. ily fluctuations are caused by barometric changes and (or) the effect of aping in nearby wells.

Figure 10 shows the hydrographs of wells $26 / 39-24 \mathrm{Kl}$ and $26 / 40-19 \mathrm{Pl}$ at termediate as determined by continuous water-level recorders, and the rometric pressure converted to feet of water at $80^{\circ} \mathrm{F}$ as read hourly from mercury barometer at Armitage Field. During the 8 -day period of record hown, there was no pumping in nearby wells that could have affected the hape of the water-level graphs. Discontinuous lenses of clay that occur hroughout the water-bearing deposits of the valley cause partial confinement of ground water. Consequently, wells drilled through these lenses into more fermeable water-bearing deposits respond to changes in barometric pressure. yost of the wells observed show a fluctuation of water level directly proportional to the magnitude of the barometric change but opposite in direction. Then the barometer rises the water level declines, and vice versa. For some wells this fluctuation may be only a very small fraction of the barometric change, whereas for certain periods in other wells this fluctuation may be as much as 80 percent of the barometric change.

In Indian Wells Valley, as in most areas, pumping in one well causes declines of water levels in nearby wells. These declines begin immediately Wor very shortly after start of pumping, owing to the relief of hydrostatic pressure in the semiconfined water-bearing deposits. In the Intermediate area, pumping of well 26/39-24R1 at a rate of $370 \mathrm{gpm}$ causes decline of water levels of about 1 foot in less than 24 hours in wells 26/39-24K1, 26/39-24Q1, 26/40-19N1, and 26/40-19P1. This rate of decline decreases in the next 24 hours. Similar pumping effects were observed in most observation wells near pumped wells during the course of the investigation.

The water-level records and hydrographs (fig. 7) show that water levels are highest in the winter or spring. The levels decline during the summer and autumn and rise again during the winter and spring. In areas where there is little or no pumpage the hydrographs show that the fluctuation is small, generally less than 2 feet a year; whereas in wells nearer centers of pumping the fluctuation may be as much as 5 feet a year. 


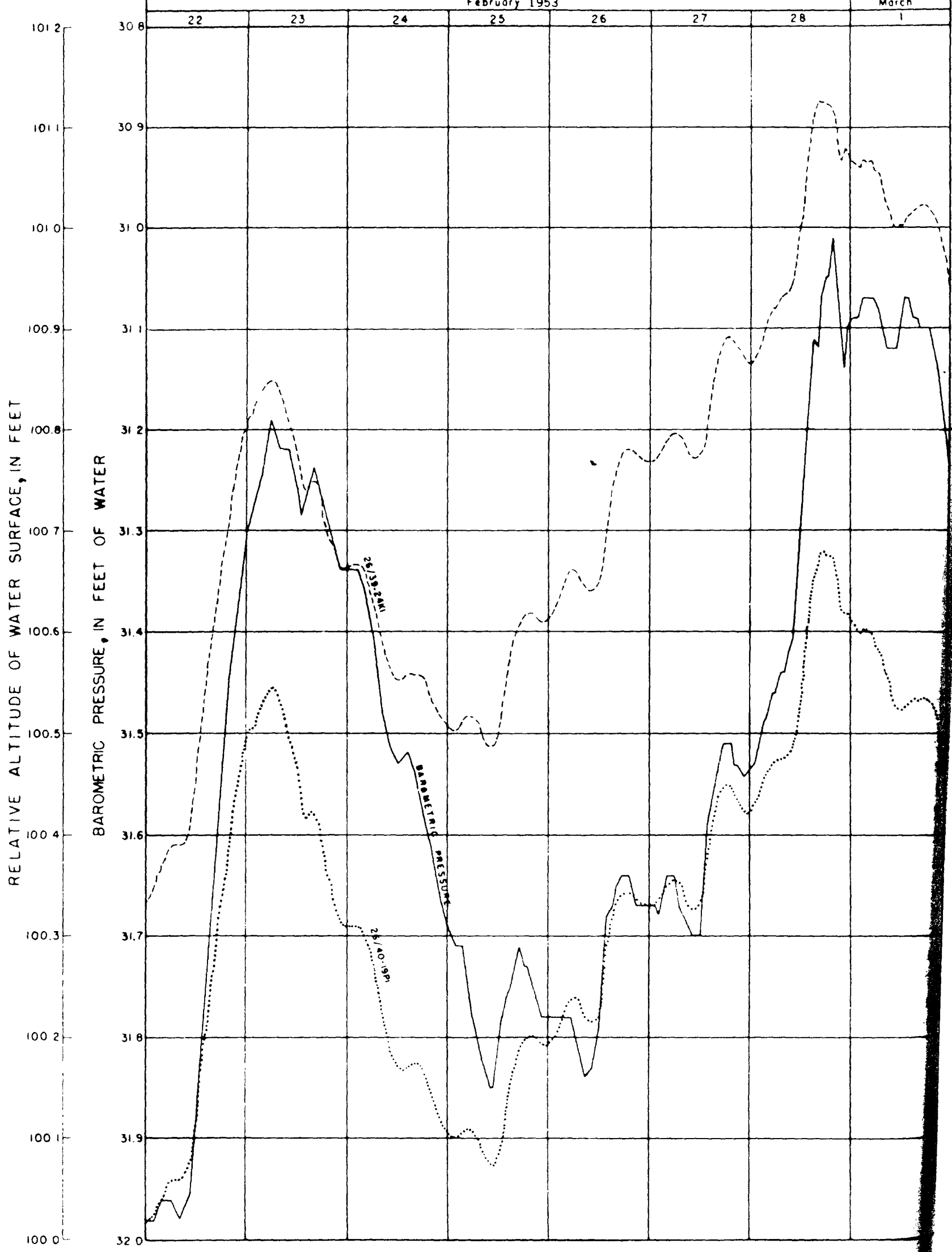

FIGURE 10... Water-level change in two wells compared to change in barometric pressl 
Chemical Quality of Ground Water

In connection with the field canvass of wells, the Geological Survey wllected 95 samples of water for chemical analysis. In addition, 115 chemical analyses of water were also assembled from the reports of mompson (1929), Wilcox, Hatcher, and Blair (1951), from well owners, and from the California Division of Water Resources. All analyses of water collected by the Geological Survey and selected analyses from other sources are given in Moyle (1963).

Standards for "good" domestic and irrigation water, described in the following sections, are in a sense arbitrary and are empirical. Therefore, they are best used to compare waters and should not be considered as standards. the

\section{Requirements for Domestic Water}

Drinking water standards of the U.S. Public Health Service (1946) for interstate carriers indicate dissolved solids should not exceed 500 ppm (parts per million) for a water of good chemical quality. However, total solids of $1,000 \mathrm{ppm}$ is permitted, which, in general, is indicated by a specific conductance (micromhos at $25^{\circ} \mathrm{C}$ ) of less than 1,500 . The upper limits given for selected chemical constituents are: Magnesium $(\mathrm{Mg}) 125 \mathrm{ppm}$, sulfate $\left(\mathrm{SO}_{4}\right)$ $250 \mathrm{ppm}$, chloride (C1) $250 \mathrm{ppm}$, and fluoride (F) $1.5 \mathrm{ppm}$. In general, a good domestic water is a soft water, or a water low in calcium and magnesium. A hardness classification for domestic water by Babbitt and Doland (1949) is given in table 4.

TABLE 4.--Hardness classification, in parts per mizlion, for domestic water

\begin{tabular}{c|c|c|c|c}
\hline Class & 1 & 2 & 3 & 4 \\
\hline $\begin{array}{c}\text { Degree of } \\
\text { hardness }\end{array}$ & Soft & Slightly hard & Moderately hard & Very hard \\
\hline $\begin{array}{c}\text { Hardness } \\
(p p m)\end{array}$ & $0-55$ & $56-100$ & $101-200$ & $200-500$ \\
\hline
\end{tabular}


Water containing more than $1.5 \mathrm{ppm}$ fluoride is not recommended by the U.S Public Health Service (1946) for drinking water. A water containing much in excess of $1.5 \mathrm{ppm}$ of fluoride, if used for drinking by children during calcification or formation of the teeth, causes a condition of the teeth known as mottled enamel.

Chloride in drinking water slightly in excess of $250 \mathrm{ppm}$, although not harmful, has an unpleasant taste. Boron is tasteless and as far as known it is believed harmless in quantities up to $30 \mathrm{ppm}$ (Goudy, 1936).

Requirements for Irrigation Water

The standards for "good" irrigation water in some respects are considerab different than standards for "good" domestic water. Water with a high calcium magnesium, iron, and fluoride content, which is almost unusable for domestic purposes, probably could be a good irrigation water, whereas a good soft domestic water with a high sodium percentage and boron in excess of 3 or $4 \mathrm{ppm}$ would be unsuitable for the irrigation of most plants.

According to Wilcox (1948), the total dissolved solids in irrigation water should be less than $1,400 \mathrm{ppm}$, which, in general, is indicated by specific conductance of less than 2,000 micromhos. Of the total cations, the percentage equivalents of sodium should be less than 65 percent. Sodium ions in water tend to disperse the colloidal clay particles in a soil, resulting in a sticky soil of poor texture for the cultivation, irrigation, and growth of plants. On the other hand, calcium ions in irrigation water cause the colloidal clay particles in soil to coagulate, resulting in a more friable and better quality soil. Fortunately, under certain conditions, calcium will displace sodium, so if an excess of calcium is present in the water, the water is of satisfactory quality for irrigation. Also, according to McKee and Wolf (1963, p. 109) class 1 irrigation water should contain not more than $195 \mathrm{ppm}$ (same as 5.5 milliequivalents per liter) chloride and not more than $0.5 \mathrm{ppm}$ (same as $0.5 \mathrm{milligrams}$ per liter) boron. Chloride in excess of $350 \mathrm{ppm}$ or boron in excess of $1 \mathrm{ppm}$ is deleterious to sensitive plants, and chloride in excess of $500 \mathrm{ppm}$ or boron in excess of $2 \mathrm{ppm}$ is deleterious to most plants. 


\author{
Chemical Quality of the Main Water Body
}

In general, ground water in Indian Wells Valley occurs either as sodium arbonate 4 or sodium chloride water, low in magnesium and sulfate. 5

ure 11 is a graphic representation of the chemical quality of 11 samples of ical ground water from Indian Wells Valley. These and about 100 additional lyses (not illustrated) indicate that ground water in the valley may be buped into three general categories.

Group I water (fig. 11) generally has a sodium plus potassium $(\mathrm{Na}+\mathrm{K})$ ige between 30 and 65 percent, is low in dissolved solids (generally less an $600 \mathrm{ppm}$ ), and has a total hardness commonly ranging from 100 to $200 \mathrm{ppm}$. oup I water is also low in chloride (generally less than $100 \mathrm{ppm}$ ), boron enerally less than $1.0 \mathrm{ppm}$ ), and fluoride (generally less than $1.0 \mathrm{ppm}$ ). e chemical quality of group I water approximates the chemical quality of ring and surface water along the east side of the Sierra Nevada, and is e best quality available in Indian Wells Valley. Group I water occurs at he Inyokem and Intermediate well fields and throughout most of the area orth of Intermediate and the town of Inyokern.

Group II water is sodium bicarbonate. This group has a sodium plus otassium $(\mathrm{Na}+\mathrm{K})$ range between 65 and 99 percent; in general the dissolved olids approximate the concentrations of group I water, and total hardness anges from 30 to $100 \mathrm{ppm}$. Group II water occurs mainly in deeper zones near he weapons center main gate and extends in a zone several miles wide from the ain gate to about $1 \mathrm{mile}$ north of Intermediate. Because of the low calcium and magnesium content $(\mathrm{Ca}+\mathrm{Mg})$, the group II water is generally moderately oft and in this respect is desirable for domestic use. However, water from unused we1ls 26/40-8N1, 26/40-15N1, 26/40-18E1, 26/40-18N1 (Wilcox, Hatcher, and Blair, 1951), and 26/40-22P1 has a fluoride concentration between 2.5 to $4.0 \mathrm{ppm}$, which is above the acceptable limits of the U.S. Public Health Service (1946), and if used for human consumption, it should be blended with other water of lower fluoride concentration. Water from well 26/40-34N1 is of group II, but the fluoride concentration $(0.8 \mathrm{ppm})$ of this water is within the acceptable limit for domestic use.

4 In this report, terms describing the general chemical character of a water are used in particular senses, as in the following examples: (1) "calcium bicarbonate" designates a water in which calcium amounts to 50 percent or more of the bases and bicarbonate to 50 percent or more of the acids, in chemical equivalents; (2) "sodium calcium bicarbonate" designates a water in which sodium and calcium are first and second, respectively, in order of abundance among the bases but neither amounts to 50 percent of all the bases; and (3) "sodium sulfate bicarbonate" designates a water in which sulfate and bicarbonate are first and second in order of abundance among the acids, as above.

${ }^{5}$ Detailed chemical analyses of water are given in Moyle (1963). All analyses for which sulfates were determined were less than $250 \mathrm{ppm}$. 

GEOLOGY AND GROUND WATER IN INDIAN WELLS VALLEY. CALIF.
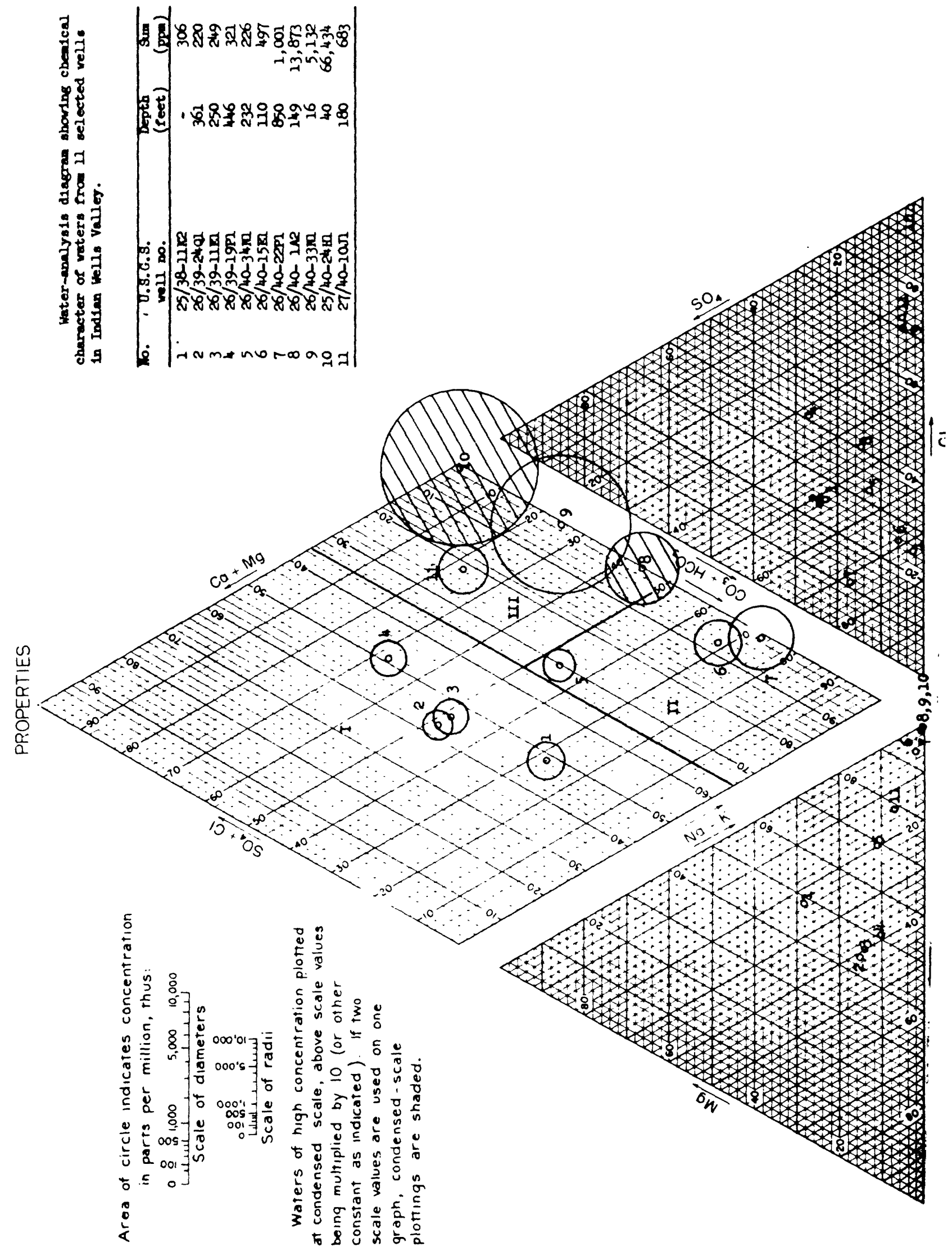
Group II water generally has a range in boron concentration from 3 to I more parts per million. Because of the high-boron concentration, water his group is generally unsuitable for all but the most tolerant agricul1. crops. This fact is not critical for domestic uses, but in part wounts for the poor yield of orchards in earlier agricultural developments findian Wells Valley.

政

ot Group II water is generally from the same source as that of group I, but -it probably has undergone base exchange--a natural process whereby the pality of ground water in moving through the deposits is modified by the quivalent replacement of calcium and magnesium in the eastward-moving water Gsodium and potassium from natural zeolites in the water-bearing beds. 1.

t* Group III water has a sodium plus potassium $(\mathrm{Na}+\mathrm{K})$ percentage range from 65 to 99 and, in general, has a much higher concentration of dissolved solids than water of groups I and II. Group III water generally occurs in He vicinity of China Lake and south and east of Ridgecrest. The concentrafon of dissolved solids of this water is generally above acceptable limits For either irrigation or domestic uses. Locally the least concentrated roup III water may be used for domestic consumption, but only if no other supply is available.

Group III water is similar in chemical character to group II, but in adition to the high sodium plus potassium percentage, the concentration of the chloride (C1) ion is generally above $250 \mathrm{ppm}$ and may be greater than \%, $000 \mathrm{ppm}$. The chemical data are not conclusive, but it seems that water in the deeper parts of the main water body in the vicinity of China Lake and in the area east of Ridgecrest may be in group II because it has a lower concentration than does water from shallower wells.

In the area several miles east and southeast of Ridgecrest, group III water does not seem to be contaminated from China Lake, but represents residual saline water of a former lake or lakes in that area. Although the group III water in the vicinity of China Lake and east of Ridgecrest is probably in poor hydraulic continuity, the water-level contours (fig. 6) for 1954 indicate that the movement of ground water, if any, was from the area east of Ridgecrest toward China Lake. It seems that a thick clay zone east of the weapons center main gate in older lacustrine deposits may form an effective barrier to such movement. However, the local residents generally believe that the high-chloride water east and southeast of Ridgecrest is contaminated from China Lake. In view of this popular misconception and because the pumping in and near Ridgecrest may cause a deterioration of water quality by drawing in locally derived high-chloride water from the area to the east and southeast, periodic measurements of water level and water sampling for chemical analysis to determine the source and extent of any such deterioration should be continued. 
Wells at Intermediate seem to lie west of any barrier effect that the clay of the older lacustrine deposits may afford. Therefore, a prolonged drawdown of water levels below an altitude of 2,175 feet might cause migratic of group III water from the margins of China Lake toward Intermediate, resul ing in a deterioration of chemical quality of the water in that area. Thus, even though the chemical quality of the water at Intermediate is not in immediate danger of contamination, a program of periodic water-level measure. ments and periodic sampling to determine progressive change in chemical qual: between China Lake and Intermediate is desirable. Such a program would moni the status of water quality and thus would provide time to plan for alternat sources of supply if deterioration in the well field seemed to be developing

The wells at Inyokern are about 9 miles from sources of poor-quality water. Therefore, continued pumpage at the present (1954) rate would probab: have no appreciable effect on the water quality in this area.

\section{Well Yields}

The yields of wells in Indian Wells Valley range from 1 to $2,000 \mathrm{gpm}$. In general the yield of adequately developed wells is roughly proportional ti the quantity of clean coarse well-sorted sand or gravel penetrated beneath t] water table. The wells of highest yield generally occur near the western margin of the valley, and the wells of lowest yield occur in and around the playas. Most irrigation and supply wells derive water from the younger alluvium.

Table 5 shows the pumping rate, drawdown, and specific capacity of well: in Indian Wells Valley. Specific capacity, the rate at which a well yields water per foot of drawdown, is a more reliable index for comparing the water. yielding capacities of wells than is the pumping rate. However, where relial specific-capacity data are not available, pumping rates may often be used to indicate areas of permeable water-bearing deposits.

Unusually high rates of pumping and specific capacity were sometimes reported and were usually based on an estimated rate of discharge, an inaccu: rate measurement of drawdown, or short periods of pumping. Where discharge and drawdown have been accurately determined and when the period of pumping was more than 24 hours, the specific capacities of the wells were found to bi fairly consistent. Specific capacities determined by the Geological Survey were for we11s having discharge meters. In general, these specific capacitis are lower than those based on less accurately determined or reported yield and drawdown data. 
The specific capacities of adequately developed wells of comparable depth Fonstruction in any limited area should be of the same order of magnitude. ally the specific capacities sometimes vary greatly between wells or they vary greatly with increased rate of discharge for the same well. These lations between similar wells in the same area may be due to faulty well struction, inadequate development, and (or) other factors unrelated to the Id of the water-bearing deposits.

For any well, specific capacity is generally only slightly decreased with Herately increased drawdown, but with excessive drawdown specific capacity often greatly decreased. This decrease is generally due to a greatly creased entrance loss of head of water flowing into the well. Also, for any 11, specific capacity usually decreases with the age of the well, because of logging, cementations, or corrosion of the perforations, sand entering and Irtly filling the well, or sand filling the natural or artificial gravel pack. becific capacity and rate of discharge also decrease with the regional acline of the water table as the saturated thickness of the aquifer decreases then mutually interfering wells are pumped simultaneously. For example, ell 26/39-24R1 yields $370 \mathrm{gpm}$ when pumped alone but $340 \mathrm{gpm}$ if pumped imultaneously with wells $26 / 39-24 K 1,26 / 39-24 Q 1,26 / 40-19 \mathrm{~N} 1$, and $26 / 40-19 \mathrm{P} 1$ table 5).

Wells drilled in and around the playas often penetrate thick sections clayey impermeable lacustrine deposits that yield water at very low rates, ometimes less than 1 gallon per day. On the other hand, some of these wells enetrate thin sand lenses that may yield several hundred gallons per day. ome wells in this area, deeper than $50 \mathrm{feet}$, flow or have heads above land urface (fig. 2) at least part of the year. However, the maximum rate of low of these wells does not exceed a few gallons per minute.

Flowing well 25/40-25F1, 182.6 feet deep, was pumped for 1 hour at a rate of $96 \mathrm{gpm}$ with a drawdown of 4.39 feet. Flowing well 26/40-1A2, 197.5 feet deep, was pumped for about an hour at the estimated rate of $35 \mathrm{gpm}$ with a drawdown of 27 feet. Therefore, it seems that some deep wells in the lowest part of the valley may penetrate deposits that yield moderate quantities of water. 
TABLE 5.--Pumping rate, drowdown, and specific capacity of wells in Indian Wells Valley

[Determined by the Geological Survey, except as indicated]

\begin{tabular}{|c|c|c|c|c|c|}
\hline USGS number & $\begin{array}{l}\text { Well } \\
\text { depth } \\
\text { (feet) }\end{array}$ & Date tested & $\begin{array}{l}\text { Pumping } \\
\text { rate } \\
\text { (gpm) }\end{array}$ & $\begin{array}{c}\text { Drawdown } \\
\text { (feet) }\end{array}$ & $\begin{array}{c}\text { Specific } \\
\text { capacity } \\
(\mathrm{gpm} / \mathrm{ft} \text { of } \mathrm{dd})\end{array}$ \\
\hline $25 / 38-25 P 1$ & 500 & & al, 600 & & \\
\hline $25 / 39-4 R 1$ & 200 & $10-21-53$ & 145 & 1.97 & 73 \\
\hline $12 \mathrm{R} 1$ & 180.5 & $10-20-53$ & 34 & .92 & 37 \\
\hline 3101 & 252 & & a 850 & & \\
\hline $31 \mathrm{E} 1$ & 164 & & a121 & & \\
\hline $35 N 1$ & 152.0 & $7-29-53$ & 275 & 13.24 & 21 \\
\hline $25 / 40-20 \mathrm{~F} 1$ & 182.6 & $10-21-52$ & 96 & 4.39 & \\
\hline \multirow{3}{*}{$\begin{array}{r}26 / 39-11 \mathrm{E} 1 \\
19 \mathrm{P} 1\end{array}$} & 250 & $7-29-53$ & 218 & 6.65 & 33 \\
\hline & 446 & $8-16-44$ & $\mathrm{~b} 2,500$ & b7 & 358 \\
\hline & & $\begin{array}{l}9-7-45 \\
6-1-53\end{array}$ & $\begin{array}{r}\mathrm{b} 1,984 \\
1,875\end{array}$ & b6.7 & 296 \\
\hline \multirow[t]{4}{*}{$19 Q 1$} & 367.5 & $3-14-44$ & b750 & b13 & 58 \\
\hline & & $9-7-45$ & b295 & b2.7 & $105(?)$ \\
\hline & & $3-19-53$ & 1,670 & 18.98 & 84 \\
\hline & & $3-20-53$ & 785 & 7.91 & 99 \\
\hline \multirow[t]{3}{*}{$24 K 1$} & 323.1 & $6-20-44$ & b1, 000 & b7 & $143(?)$ \\
\hline & & $9-7-45$ & b350 & b12.4 & 28 \\
\hline & & $7-14-52$ & $c 255$ & & \\
\hline $24 Q 1$ & 361 & $\begin{array}{r}11-8-44 \\
7-14-52\end{array}$ & $\begin{array}{l}\text { b } 800 \\
\text { c505 }\end{array}$ & b30 & 28 \\
\hline \multirow[t]{4}{*}{$24 \mathrm{R} I$} & 480 & $4-20-44$ & b900 & 22 & 41 \\
\hline & & $9-7-45$ & b328 & 11.5 & 28 \\
\hline & & $7-14-52$ & c 340 & & \\
\hline & & $3-5-53$ & 370 & 25.94 & 12.6 \\
\hline \multirow[t]{2}{*}{$25 \mathrm{D} 2$} & 330 & $5-\quad-50$ & b 180 & 4 & 45 \\
\hline & & $9-\quad-50$ & b 355 & 10.5 & 34 \\
\hline \multirow[t]{3}{*}{$25 \mathrm{E} 1$} & 387 & $5-\quad-51$ & b230 & b5 & 46 \\
\hline & & $7-\quad-51$ & b320 & b7 & 46 \\
\hline & & $3-\quad-52$ & b150 & b4 & 38 \\
\hline \multirow[t]{2}{*}{$30 \mathrm{Cl}$} & 340 & $6-19-44$ & b350 & b10 & 35 \\
\hline & & $9-7-45$ & b126 & b2 2.3 & 55 \\
\hline \multirow[t]{3}{*}{$30 F 1$} & 619 & $9-7-45$ & $\mathrm{~b} 2,200$ & b 27 & 81 \\
\hline & & $7-18-52$ & 1,875 & & \\
\hline & & $3-20-53$ & 2,000 & & \\
\hline
\end{tabular}

See footnotes at end of table. 
TABLE 5.--Pumping rate, drowdown, and specific capacity of wells in Indian Wells Valley--Continued

\begin{tabular}{|c|c|c|c|c|c|}
\hline USGS number & $\begin{array}{l}\text { We11 } \\
\text { depth } \\
\text { (feet) }\end{array}$ & Date tested & $\begin{array}{l}\text { Pumping } \\
\text { rate } \\
\text { (gpm) }\end{array}$ & $\begin{array}{c}\text { Drawdown } \\
\text { (feet) }\end{array}$ & $\begin{array}{c}\text { Specific } \\
\text { capacity } \\
(\mathrm{gpm} / \mathrm{ft} \text { of } \mathrm{dd})\end{array}$ \\
\hline$\frac{6}{65 / 40-} \begin{array}{l}1 \mathrm{~A} 2 \\
5 \mathrm{P} 1\end{array}$ & $\begin{array}{r}197.5 \\
89.3\end{array}$ & $\begin{array}{l}3-17-54 \\
8-4-53\end{array}$ & $\begin{array}{l}d 35 \\
247\end{array}$ & 27 & \\
\hline $19 \mathrm{~N} 1$ & 306 & $\begin{array}{l}9-7-45 \\
7-14-52\end{array}$ & $\begin{array}{l}\mathrm{b} 450 \\
\mathrm{c} 320\end{array}$ & $b 31.7$ & 14 \\
\hline $19 \mathrm{Pl}$ & 261.0 & $\begin{array}{r}11-8-44 \\
7-14-52\end{array}$ & $\begin{array}{l}\text { b 700 } \\
\text { c230 }\end{array}$ & b39 & 18 \\
\hline $20 \mathrm{~N} 1$ & 190.1 & $9-7-45$ & b127 & b13 & 10 \\
\hline $22 \mathrm{P} 1$ & 850 & $2-23-54$ & e 190 & e 246 & e. 8 \\
\hline $28 \mathrm{~J} 1$ & & $12-30-48$ & a152 & & \\
\hline $30 \mathrm{E} 2$ & 402 & 1954 & al, 680 & & \\
\hline $32 \mathrm{E} 1$ & 300 & & $\mathrm{a} 1,720$ & & \\
\hline $32 \mathrm{~N} 1$ & 391 & & a1, 200 & & \\
\hline $33 A 1$ & 400 & 1950 & a 850 & 253 & 16 \\
\hline $33 P 3$ & & 1950 & a250 & 28 & 31 \\
\hline $34 \mathrm{~N} 1$ & 232 & $\begin{array}{l}9-7-44 \\
8-7-53\end{array}$ & $\begin{array}{r}\text { b1 } 1,020 \\
1,200\end{array}$ & 21.9 & 47 \\
\hline $36 \mathrm{~A} 1$ & 270.0 & $2-8-54$ & 75 & 6.3 & 12 \\
\hline $27 / 40-4 \mathrm{~B} 2$ & 375 & & a650 & & \\
\hline $4 \mathrm{~L} 1$ & 252 & $7-\quad-50$ & b1 1,400 & b30 & 47 \\
\hline & & $4-2-53$ & b950 & b25 & 38 \\
\hline $8 \mathrm{~A} 1$ & 440 & & $\mathrm{a} 1,500$ & & \\
\hline $10 \mathrm{C} 1$ & 250 & $11-18-53$ & a1,900 & & \\
\hline
\end{tabular}

a. Reported.

b. From owner's record.

c. Wells 26/39-24K1, 26/39-24Q1, 26/39-24R1, 26/40-19N1, and 26/40-19P1 pumping simultaneously.

d. Estimated by Geological Survey.

e. Pumping rate, drawdown, and specific capacity not representative owing to incomplete development of test well. 
Transmissibility of the Alluvium

Transmissibility may be defined as the rate of flow of water in gallons per day through a vertical cross section of an aquifer 1 mile in width, having a height equal to the thickness of the saturated part of the aquifer, under a hydraulic gradient of 1 foot per mile. Thus, values of transmissibility are expressed in gallons per day per foot (Wenzel, 1942, p. 87).

Field permeability may be defined as the rate of flow of water in gallons per day through a 1 -foot thickness of aquifer 1 mile in width under a hydraulic gradient of 1 foot per mile. The field permeability times the saturated thickness of the aquifer, in feet, is equivalent to the transmissibility.

The most objective and reliable method for the determination of the transmissibility of an aquifer is by means of a pumping test. Ideally such a test involves pumping of one well at a constant rate, while the rate of decline of water levels is observed in properly situated nearby nonpumping observation wells. During pumping, a progressively increasing cone of depression or cone of pressure relief is formed, whose rate of growth and shape are functions of the aggregate permeabilities of the various beds of the saturated section or the transmissibility of the aquifer within the area of influence of the pumping well. After pumping has ceased, the rates of recovery to the initial or static water levels in the pumped and observation wells are observed in a similar manner, as the cone of depression contracts and disappears. Corrections must be made for natural or externally caused fluctuations in water levels during the test. Such fluctuations may be caused by changes in atmospheric pressure, evapotranspiration, regional trend of water levels, local variations in permeability due to the lenticular character of the alluvium, impermeable boundaries, and by interference from nearby pumped wells.

The heterogeneity of the alluvial fill of the valley makes it possible to consider it as a single hydraulic unit; that is, all clay, silt, and other material of low permeability are considered as lenticular in character, thereby providing hydraulic continuity among the interspersed permeable materials. Therefore, a single pumping test, utilizing a well discharge for a sufficiently long period of time--perhaps months or years--would theoretically furnish data for the calculation of a transmissibility for the entire volume of alluvial fill. However, economic and other considerations make it necessary to make tests of short duration and generally at low rates of discharge. The results of each such test may be considered as representative of the transmissibilityd of a cylinder of materials within the saturated zone--a cylinder whose diamete is equal to that of the area of influence of the pumping well. For the averas: 2 - to 3-day test where water is semiconfined, as in Indian Wells Valley, and where the rate of pumping is of the order of magnitude of several hundred gallons per minute, the diameter of the cylinder tested may be 4 or more milc. 
The value for transmissibility obtained from a pumping test applies only that part of the aquifer whose water levels or artesian pressures are lected by the pumping. For this reason a number of tests were made at lected locations in order to secure a satisfactory mean value for the ransmissibility of the aquifer along a north-trending line through the entral part of Indian Wells Valley.

Where observation wells were lacking it was necessary to pump an isolated ell and observe, after pumping ceased, the rate of recovery of water level in the pumped well to the initial static level. This method permits the determikation of a value for transmissibility which is accurate provided that incontrolled extraneous influences are not present.

Pumping Tests

Detailed and long pumping tests were made at the wells at Intermediate and $1 \frac{1}{2}$ miles north of Sandquist Spa. At Intermediate, supply well 26/39-24RI was pumped for 64 hours; careful and continuous observations of the drawdown of water levels during pumping and the recovery of water levels after cessation of pumping were made in nearby wells 26/39-24K1, 26/39-24Q1, 26/40-19N1, and 26/40-19P1. Also, fluctuations of water levels were observed in wells 26/39-25D1 and 26/39-25D2 of the American Potash and Chemical Co., and records of discharge were made for wel1 26/39-25D2, which was pumped continuously at a varying rate during the test. In the test north of Sandquist Spa, supply well 25/39-35N1 was pumped for 48 hours and observations were made in nearby wells 25/39-35N2 and 26/39-2D1. Recovery tests, utilizing recovery measurements after the pumping well had been stopped, were made for wells 25/39-4R1, 25/39-12R1, and 26/39-11E1. In addition to these five tests, recovery was observed in several additional wells, but the tests were not subject to accurate control. Accordingly, the results were not used in the estimate of transmissibility. Table 6 shows the transmissibility of the alluvium obtained for the five pumping tests.

For the area $1 \frac{1}{2}$ miles north of Sandquist Spa the average transmissibility obtained from the three wells is $56,000 \mathrm{gpd} / \mathrm{ft}$ (gallons per day per foot) and is considered reliable. At Intermediate a weighted average of $150,000 \mathrm{gpd} / \mathrm{ft}$ was derived. Recovery observations show some slight interference from well 26/39-25D2 of the American Potash and Chemical Co., indicating that the value of $150,000 \mathrm{gpd} / \mathrm{ft}$ is conservative. 
TABLE 6.--Transmissibility of the alluvium in Indian Wells Valley determined from pumping tests

\begin{tabular}{|c|c|c|c|c|c|}
\hline Location & Well number & $\begin{array}{l}\text { Depth } \\
\text { of } \\
\text { well } \\
\text { (ft) }\end{array}$ & $\begin{array}{l}\text { Saturated } \\
\text { thickness } \\
(\mathrm{ft})\end{array}$ & $\begin{array}{l}\text { Transmis- } \\
\text { sibility } \\
\text { from test } \\
\text { (gpd/ft) }\end{array}$ & $\begin{array}{l}\text { Transmissibility } \\
\text { extrapolated for } \\
400 \mathrm{ft} \text { of satu- } \\
\text { rated thickness } \\
\text { (gpd/ft) }\end{array}$ \\
\hline $\begin{array}{l}1 \frac{1}{2} \text { miles north of } \\
\text { Sandquist Spa }\end{array}$ & $\begin{array}{l}25 / 39-35 N 1 \\
25 / 39-35 N 2 \\
26 / 39-2 D 1\end{array}$ & 152 & 95 & $\begin{array}{l}60,000 \\
44,000 \\
64,000\end{array}$ & $\begin{array}{l}253,000 \\
185,000 \\
269,000\end{array}$ \\
\hline $\begin{array}{l}8 \text { miles north of } \\
\text { Intermediate }\end{array}$ & $25 / 39-12 \mathrm{R} 1$ & 180.5 & 163.5 & 62,000 & 152,000 \\
\hline $\begin{array}{l}6 \frac{1}{2} \text { miles north of } \\
\text { Sandquist } \mathrm{Spa}\end{array}$ & $25 / 39-4 R 1$ & 200 & 143 & 87,000 & 243,000 \\
\hline Sandquist Spa & $26 / 39-11 E 1$ & 250 & 148 & 116,000 & 314,000 \\
\hline Intermediate & $\begin{array}{l}26 / 39-24 R 1 \\
26 / 39-24 K 1 \\
26 / 39-24 Q 1 \\
26 / 40-19 N 1 \\
26 / 40-19 P 1\end{array}$ & 480 & 328 & $\begin{array}{l}146,000 \\
155,000 \\
140,000 \\
146,000\end{array}$ & $\begin{array}{l}178,000 \\
189,000 \\
171,000 \\
178,000\end{array}$ \\
\hline
\end{tabular}

If the aquifer containing the main water body were more or less homogeneous throughout, the values of transmissibility obtained from the five tests would be corrected for partial penetration. However, because of the very large differences between vertical and horizontal permeability of the deposits as evidenced by the high barometric efficiency of the wells (fig. 10), by the lenticular character of the deposits (fig. 3), by the differences in head or water level between shallow and deep wells such as 26/40-22P1 and 22N1, and by the differences in the pumping-test results themselves, the transmissibilitiest obtained probably apply almost wholly to the saturated deposits tapped by the wells. Accordingly, in order to estimate the transmissibility for a saturated thickness of 400 feet, which extends to an average depth of 500 feet below lant surface, the results have been extrapolated and are shown in the last column of table 6 . The average of these extrapolated values is rounded to $200,000 \mathrm{gpd} / \mathrm{ft}$ and is used in the computations involving the quantity of ground-water movement across the north-south line along which the tests were made. 
Observations of water-level recovery in wells penetrating the deeper water-bearing materials (below 500 feet) could be made only in well 26/40-22Pl, perforated from 530 to 850 feet, after this deep test well had been partly developed and pumped for the purpose of sampling. Entrance losses were great, the period of pumping was short, development was incomplete, and the very small diameter of the casing in proportion to the pump column prevented accurate observations during the early moments of recovery. Nevertheless, the meager data suggest that the transmissibility of the zone contributing water to this well, perforated from 530 to 850 feet, may be 40,000 to $50,000 \mathrm{gpd} / \mathrm{ft}$. Therefore, the transmissibility for the total thickness of saturated material may be about $250,000 \mathrm{gpd} / \mathrm{ft}$. However, it is not known whether or to what extent the permeable zone of well 26/40-22Pl is connected with a similar zone beneath the Intermediate area and, in turn the extent to which that zone may be connected with the shallower zone tapped by the wells. Therefore, to what extent the transmissibility of any deeper zone at Intermedjate is additional to the transmissibility determined in the tests is not known.

\author{
Underflow at Midvalley
}

From transmissibility and other data the total quantity of ground-water underflow at midvalley under natural conditions is estimated along the 1921 position of the 2,200-foot water-level contour (fig. 5). The position of this water-level contour approximately coincides with the line of pumping tests and also extends across the central part of the valley as an arc between impermeable older lacustrine deposits east of the weapons center main gate on the south and the unnamed volcanic rocks at the north end of the basin. Therefore, under natural conditions unaffected by pumping, all recharge from the west and south moves to the east toward the area of natural discharge as underflow across this water-level contour.

The quantity of underflow is estimated from transmissibility and other data, according to the equation:

$$
Q=\operatorname{TId} \times 0.00112
$$

where $Q$ is the underflow, in acre-feet per year,

$T$ is the coefficient of transmissibility for the total thickness of the saturated section, in gallons per day per foot for each lineal mile,

$I$ is the hydraulic gradient of the water surface, in feet per mile,

$d$ is the lineal distance, in miles, along a selected water-level contour,

and

0.00112 is the conversion factor from gallons per day to acre-feet per year. 
From a coefficient of transmissibility (T) of $200,000 \mathrm{gpd} / \mathrm{ft}$, a hydraulic gradient ( $I$ ) of 4.8 feet per mile, and a lineal distance (d) along the 1921 position of the 2,200-foot water-level contour of 13.6 miles, underflow (Q) at midvalley is calculated to be:

$$
\begin{aligned}
& Q=200,000 \times 4.8 \times 13.6 \times 0.00112 \\
& Q=15,000 \text { acre-feet per year. }
\end{aligned}
$$

This estimate of underflow, based on the transmissibility of the alluvium to 500 feet below the 1 and surface, is probably a minimum quantity because it does not allow for any ground-water underflow below 500 feet.

With regard to the underflow in the deposits deeper than 500 feet below 1 and surface, the transmissibility of 40,000 to $50,000 \mathrm{gpd} / \mathrm{ft}$, crudely determined for the older alluvium from 530 to 850 feet in well 26/40-22P1, suggests by use of the above formula an additional underflow at midvalley of roughly 3,000 acre-feet per year. The sum of the two estimated suggests a total underflow of 18,000 acre-feet per year. However, with respect to the postulated underflow of 3,000 acre-feet below $500 \mathrm{feet}$, section $E-E^{\prime}$ (fig. 3) shows that the older alluvium is truncated on the east by the Argus fault zone. Also, as indicated on sections $B-B^{\prime}$ and $E-E^{\prime}$ the western limit of confining materials (playa deposits, and younger and older lacustrine deposits) is approximately at midvalley or slightly east. The electric $10 \mathrm{~g}$ of well 26/40-22P1 indicates that here older alluvium underlies older lacustrine deposits below 530 feet below the land surface. It is also presumed that older alluvium overlies older lacustrine deposits below 700 feet at the site of well 25/40-25P1.

Thus, subsurface flow beneath these confining deposits can escape only very slowly by vertical leakage, whereas ground water in the upper zone continues to move at a more rapid rate largely through the younger alluvium. This slow rate of movement in the older alluvium is suggested by poorly permeable material described in logs of wells drilled in the area of confinement and by the chemical quality of deeper water. The extremely high percentage (98 percent) of sodium in the water from the deep zone (530 to 850 feet) of well 26/40-22P1 indicates almost complete base exchange of calcium ions by sodium ions which suggests slow movement of the water.

In the area of confined water the degree of confinement becomes progressively greater from west to east, and the deeper part of the ground-water body within this area probably occurs in older alluvium below older lacustrine deposits. Also, where underflow in the deep zone approaches the area of transition from unconfined to confined water, there is a progressive decrease in the quantity and rate of upward flow from the deeper ground-water zones to areas of discharge. However, information now available does not permit the quantitative evaluation of the rate of vertical leakage. On the other hand, the total section of water-bearing deposits in the center of the valley probably is thicker than that indicated by the log of test well 26/40-22P1. This additional thickness of saturated section to some extent would compensate for the lower transmissibility at the deep test well. 
From the preceding discussion the total underflow at midvalley is estima$d$ to be 15,000 acre-feet per year. Accordingly, based principally on the striction to deeper movement caused by the westward extent of impermeable Ider lake clays below a depth of about 500 feet and by the Argus fault zone, his estimate is used in subsequent sections of this report. ,

\section{Ground-Water Discharge}

Prior to the advent of man in Indian wells Valley ground-water discharge from the main water body occurred principally by evapotranspiration and in very small part by ground-water underflow or outflow to Salt Wells valley. Since the development of large-capacity wells, discharge by pumpage has increased steadily and in 1954 was a substantial part of the total discharge from the main water body.

Evapotranspiration

Evapotranspiration, the combined processes of evaporation from moist soil and transpiration of plants, identified as phreatophytes, whose roots draw from ground water or the capillary fringe, occurs in the eastern part of Indian Wells Valley in the vicinity of China Lake.

The rate of evaporation from soil varies proportionally with the depth to the ground-water surface. When ground water is at land surface there is a definite relation between the rate of soil evaporation and the direct evaporation from a free water surface. When the ground-water surface reaches a depth of from 4 to 9 feet, depending on the character of the soil, it is generally believed that evaporation ceases. However, field observations in Indian Wells Valley indicate that locally in very tight clay, evaporation may lower the water table in wells to as much as 10 feet below the land surface.

Where phreatophytes grow in the eastern part of the valley the rate of transpiration of ground water varies in proportion to density of plant growth and depth to ground water. The only phreatophytes are pickleweed (Allenrolfea occidentalis) and saltgrass (Distichlis seicata). These species generally do not draw water from a depth greater than 8 feet (Meinzer, 1927). They both grow in brackish water and may grow in the same area, but in Indian Wells Valley they generally grow in separate areas. The pickleweed generally grows in areas of greater salinity than saltgrass. In areas of maximum salinity neither species grows. 
Water levels in wells in the area of evapotranspiration in Indian We1 s Valley show an annual fluctuation. The highest level is generally about March 15-30, and the level gradually recedes until about September 15-30, after which it begins to rise. During the period 1912-53, intermittent records from 30 wells (table 7) in the area of evapotranspiration indicate that the range in water-level fluctuations was from 0.2 foot in well 25/40-8Al to more than 3.2 feet in well 24/40-35Jl and for all wells averaged less than 1 foot.

In 1912 Lee (1913) classified the types of moist lands in and around China Lake in six units to which he assigned annual rates of evaporation for the purpose of determining total evapotranspiration from ground water in the discharging area. The method of Lee is reliable, but his estimate of 31,600 acre-feet per year is no longer considered applicable. This is because the work of Lee was done in 1912 when only comparatively poor maps and no aerial photographs were available and when little work had been done on rates of evapotranspiration.

More recent work by Smith and Skarn (1927), Lee (1942), Young and Blaney (1942), Blaney (1952), and others indicates that the rates of evaporation assigned in 1913 to the various units of discharge were probably too high. Therefore, the values for evapotranspiration have been revised. Rates for bare soil or a very sparse growth of pickleweed or saltgrass (10 percent density or less) have been determined largely from work of Smith and Skarn (1927) and partly from others.

The consumptive use for areas covered by saltgrass or pickleweed was calculated from the formula developed by Blaney and Criddle (1949) and Blaney (1951), as follows:

$$
U=\Sigma k f=K F
$$

where $U$ is the consumptive use of vegetation for any period,

$k$ is the monthly empirical consumptive-use coefficient for the type of vegetation in a particular locality,

$f$ is a monthly consumptive-use factor obtained by multiplying the mean monthly temperature by the monthly percentage of daytime hours of the year,

$K$ is an empirical consumptive-use coefficient for the growing period,

and

$F$ is the sum of the monthly consumptive-use factors for the growing period.

Consumptive-use coefficients $(k)$ for a dense (100 percent) saltgrass growth for various depths to ground water in Indian Wells Valley are shown in table 8 . These values also have been applied to pickleweed. 
TABLE 7.--Range in water-level fluctuations beneath the moist lands in and around China Lake, 1912-53

(Based on intermittent records)

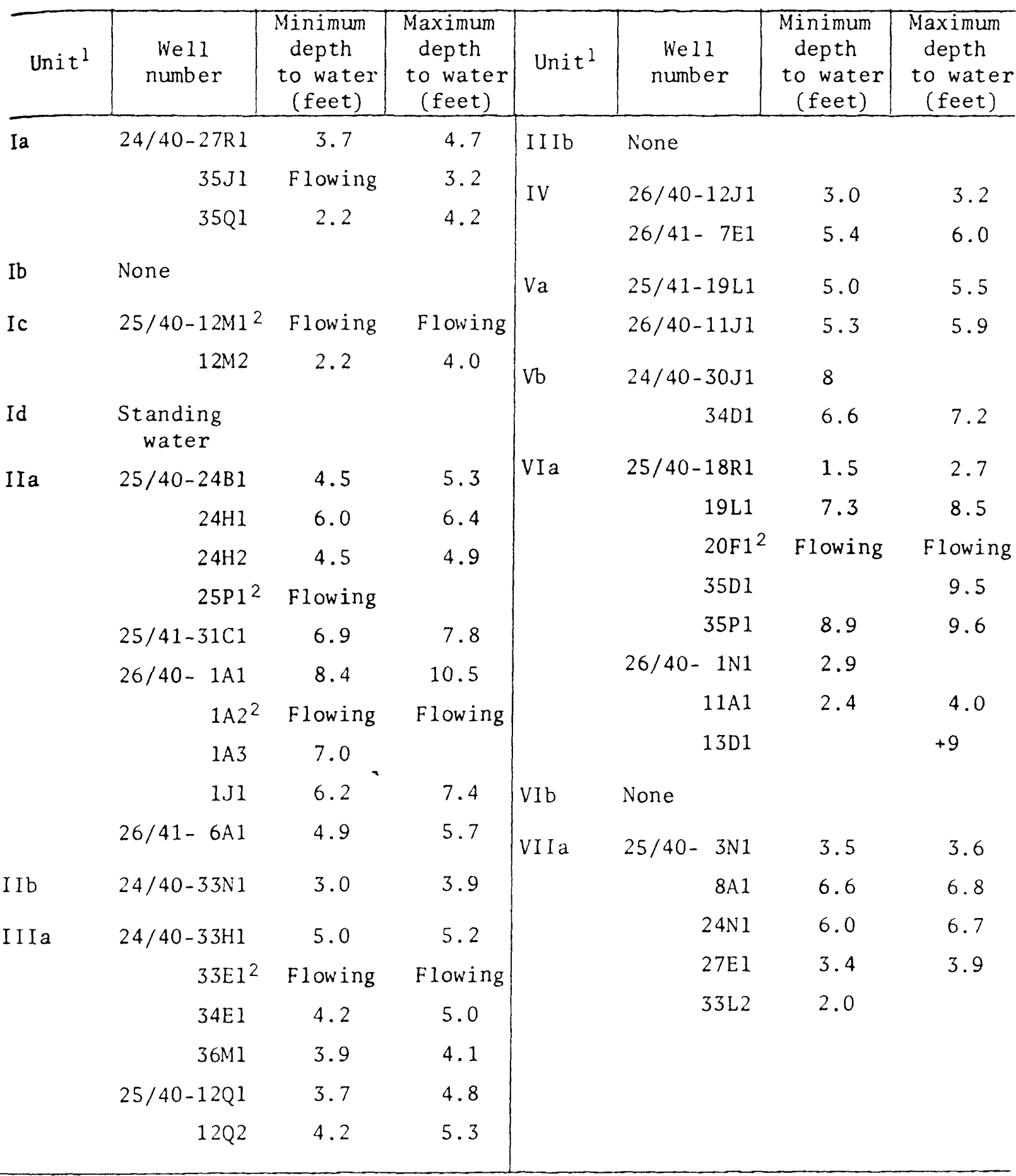

${ }^{1}$ For description and areal distribution of units see table 9 and figure 13 .

${ }^{2}$ Deep well not used in estimating average depth to water. 
TABLE 8.--Consumptive-use coefficients ${ }^{1}$ for a dense saltgrass growth in Indian Wells Valley

\begin{tabular}{c|c|c|c}
\hline $\begin{array}{c}\text { Depth to water } \\
\text { (feet) }\end{array}$ & $\begin{array}{c}\text { Coefficient } \\
k\end{array}$ & $\begin{array}{c}\text { Depth to water } \\
\text { (feet) }\end{array}$ & $\begin{array}{c}\text { Coefficient } \\
k\end{array}$ \\
\hline 1 & 0.8 & 5 & 0.3 \\
2 & .6 & 6 & .2 \\
3 & .4 & 7 & .2 \\
\hline
\end{tabular}

${ }^{l}$ Values suggested by H. F. Blaney, Senior Irrigation Engineer, U.S. Department of Agriculture, Los Angeles, Calif.

Figure 12 shows the revised rates of evaporation and evapotranspiration assigned to areas of fine-grained bare soil, of 100-percent saltgrass cover, and of 25-percent saltgrass or pickleweed cover for various depths to ground water in Indian Wells Valley.

Figure 13 shows an areal classification by the Geological Survey of the types of moist land in and around China Lake in 1953, and table 9 shows the estimated annual rate and total evaporation or evapotranspiration for 15 units of ground-water discharge for 1912 and for 1953. The estimated annual groundwater discharge, in acre-feet, in each unit was determined by multiplying the area, in acres, by the estimated rate of evaporation or evapotranspiration, in feet. Total ground-water discharge by evapotranspiration in 1953 was approximately 8,000 acre-feet.

Water-level measurements in 1953 indicate that since the work of Lee (1913) in the area of evapotranspiration, there has been a net change of water table, as follows: A decline of about 1.5 feet in units IIa and Vb; a decline of about 0.5 foot in units VIa, VIb, and VIIa; a rise of about 1.0 foot in units $\mathrm{Ia}$ and IIb; and a rise of about 0.5 foot in units $\mathrm{Ib}$ and IC. There has been no measurable change in the other units. Therefore, as shown in table 9, total evapotranspiration from moist lands in and around China Lake in 1912 as reestimated by the Geological Survey from Lee's (1913) data was approximately 11,000 acre-feet per year. This suggests a decrease in the annual evapotranspiration from 1912 to 1953 of approximately 3,000 acre-feet per year. The decrease is presumably due to the increase in ground-water pumpage since 1912 which has intercepted ground water that normally was lost by natural processes, and so has caused a net decline of water levels beneath the moist areas shown in figure 13. 


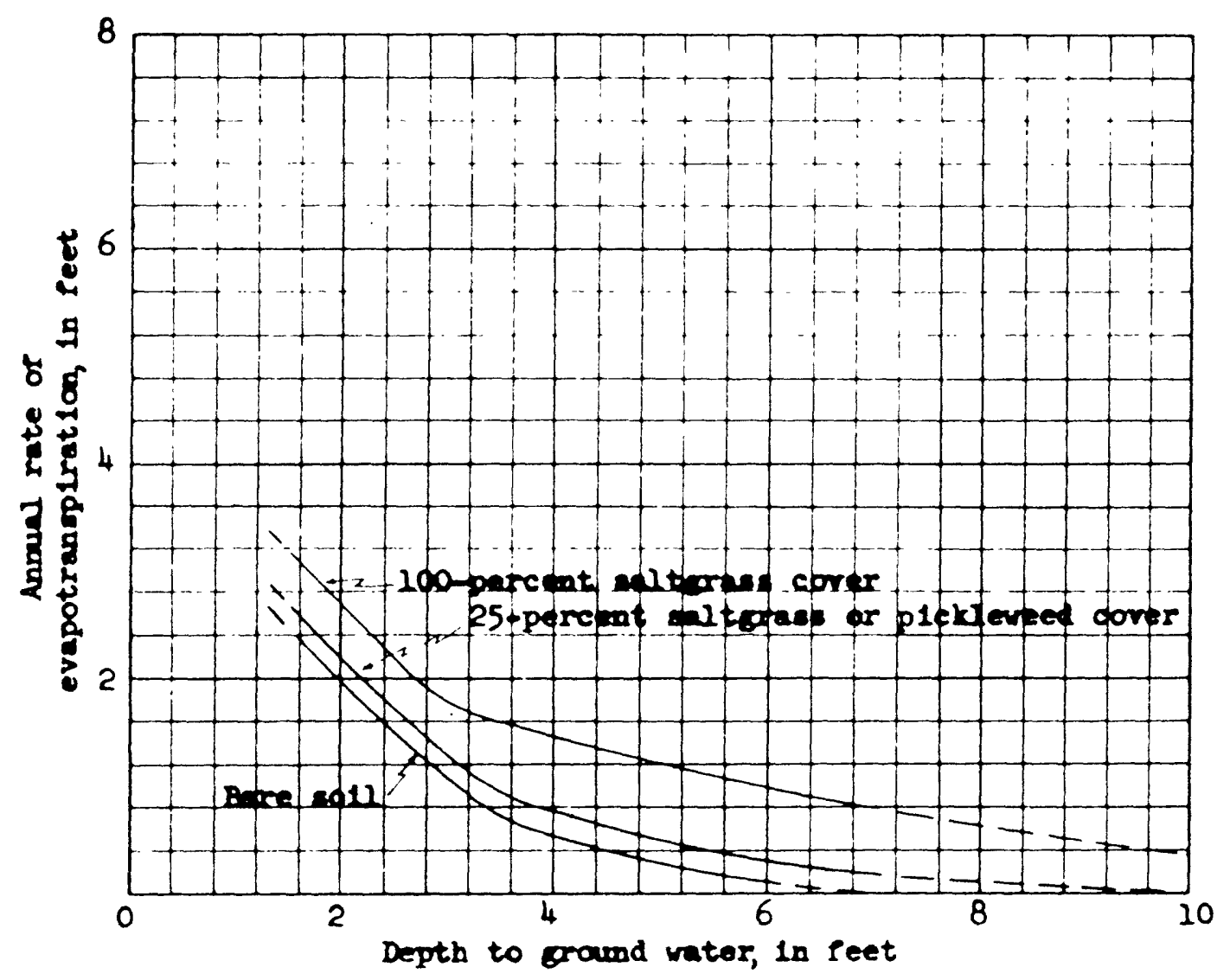

FIGURE 12.- Relation of evapotranspiration to depth of ground water in Indian Wells Valley. California. 


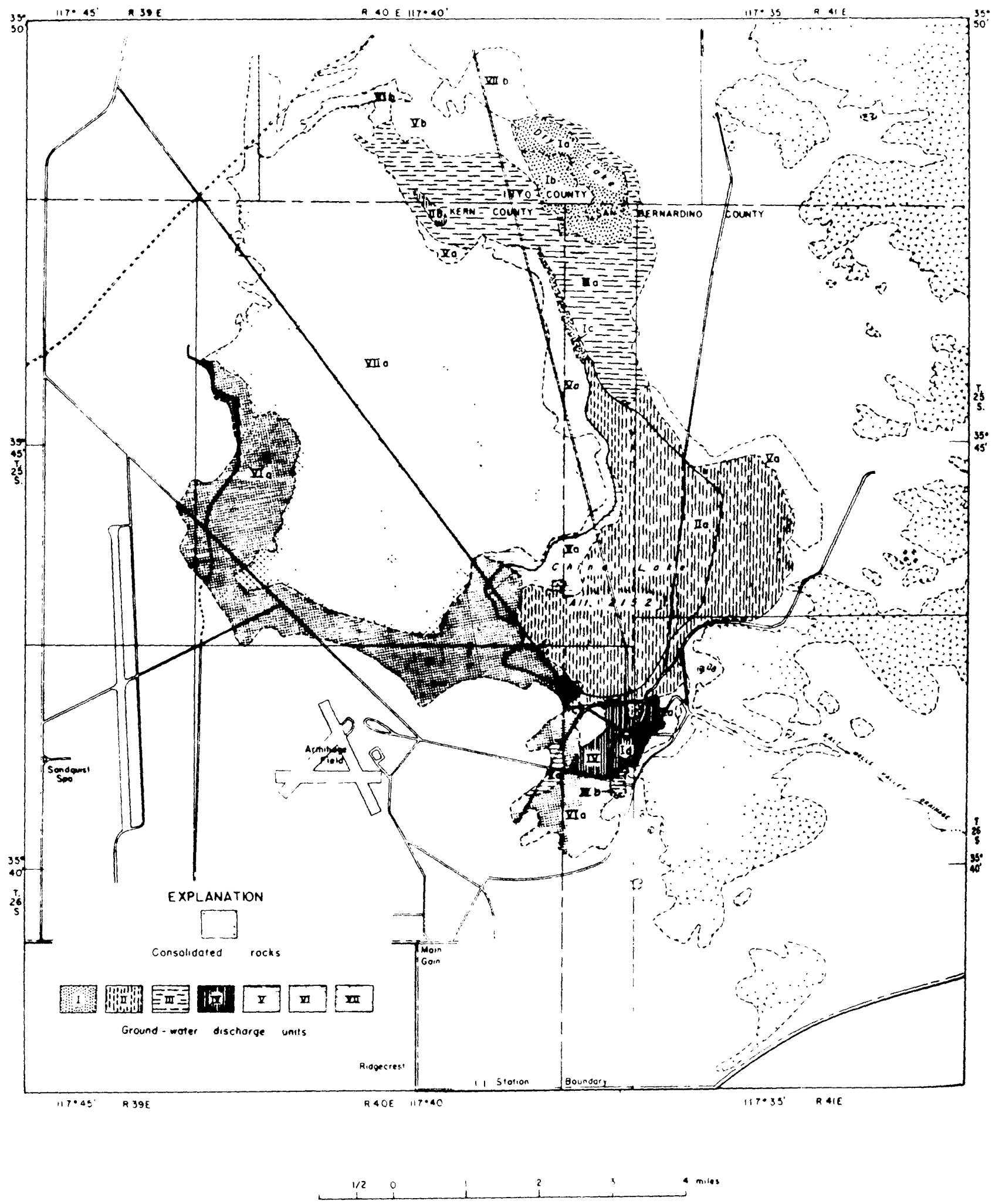

FIGURE 13.-. Playa area showing ground-water discharge units in the autumn of $195 y^{3}$ 


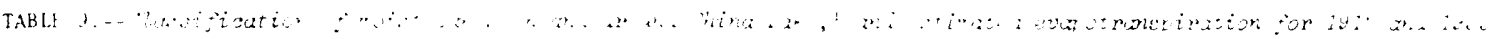

\begin{tabular}{|c|c|c|c|c|c|c|c|c|c|}
\hline \multirow[t]{2}{*}{ onit } & \multirow[t]{2}{*}{ Location } & \multirow[t]{2}{*}{ lterertption } & \multirow[t]{2}{*}{$\begin{array}{c}\text { Area } \\
\text { (acres) }\end{array}$} & \multicolumn{2}{|c|}{$\begin{array}{c}\text { Average depth } \\
\text { to water } \\
\text { (feet) }\end{array}$} & \multicolumn{2}{|c|}{$\begin{array}{c}\text { Estinated annual } \\
\text { evapotranspiration } \\
\text { (feet) }\end{array}$} & \multicolumn{2}{|c|}{$\begin{array}{l}\text { Fstimated } \\
\text { discharge } \\
\text { (acre-feet) }\end{array}$} \\
\hline & & & & 1912 & 1953 & 1912 & 1953 & 1912 & $1 \quad 1953$ \\
\hline ia & $\begin{array}{l}\text { Bottom of dry } \\
\text { lake about } \\
2 \text { miles north of } \\
\text { China Lake }\end{array}$ & $\begin{array}{l}\text { Bare clay with slight alkdl: film, surface } \\
\text { wet and generally smooth }\end{array}$ & 540 & 3.5 & 2.5 & 0.7 & 1.5 & 380 & 8: \\
\hline $\mathbb{b}$ & $\begin{array}{l}\text { Southwest margin } \\
\text { of dry lake } \\
\text { bottom }\end{array}$ & $\begin{array}{l}\text { Pickleweed about } 25 \text {-percent density; } \\
\text { some alkali fil-, surface wet and } \\
\text { generally puffy }\end{array}$ & 550 & 3.5 & 3 & .9 & 1.3 & 500 & 72 \\
\hline Ic & $\begin{array}{l}\text { North extension } \\
\text { of China Lake }\end{array}$ & $\begin{array}{l}\text { Generally bare snooth clay with alkali } \\
\text { film, surface net }\end{array}$ & 110 & 3.5 & 3 & .7 & 1.1 & 80 & 12 \\
\hline Id & $\begin{array}{l}\text { Sump south of } \\
\text { China Lake } \\
\text { bottom }\end{array}$ & Standing water & 0 & 0 & & 5.6 & 5.0 & 35 & 5 \\
\hline II a & $\begin{array}{l}\text { China Lake } \\
\text { bottom }\end{array}$ & $\begin{array}{l}\text { Bare hard clay with areas roughened by } \\
\text { surface swelling, molst beneath thin } \\
\text { surface crust, little or no surface } \\
\text { alkali showing }\end{array}$ & 5,400 & 4.5 & 6 & 0.5 & 0.1 & 2,700 & 54 \\
\hline IIb & $\begin{array}{l}\text { Small area } \\
\text { about } 1 \mathrm{mile} \\
\text { west of } \mathrm{dry} \text { lahe }\end{array}$ & Same as II Ia & 60 & 4.5 & 3.5 & .5 & .7 & 30 & 4 \\
\hline III a & $\begin{array}{l}\text { Border area } \\
\text { north of } \\
\text { China Lake }\end{array}$ & $\begin{array}{l}\text { Sparse growth of saltgrass and (or) } \\
\text { pickleweed, alkali crust much broken } \\
\text { and puffed up by swelling, moist } \\
\text { beneath surface crust, locally } \\
\text { moist at surface }\end{array}$ & 3,000 & 4.5 & 4.5 & 0.7 & 0.7 & 2,100 & 2,10 \\
\hline II Ib & $\begin{array}{l}\text { Border area } \\
\text { south of Id }\end{array}$ & $\begin{array}{l}\text { Same as IIla, but in part may be caused } \\
\text { by sewage effluent }\end{array}$ & 40 & 4.5 & 4.5 & .7 & .7 & 30 & $j$ \\
\hline IV & $\begin{array}{l}\text { Border area } \\
\text { south of } \\
\text { China Lake }\end{array}$ & $\begin{array}{l}\text { Bare soil, locally sparsely vegetated, } \\
\text { gray alkali crust with white spots; } \\
\text { hard, brittle, and puffed up; moist } \\
\text { beneath surface crust }\end{array}$ & 470 & 4.5 & 4.5 & 0.5 & 0.5 & 240 & 24 \\
\hline $\mathrm{Va}$ & $\begin{array}{l}\text { Areas bordering } \\
\text { China Lake in } \\
\text { narrow bands }\end{array}$ & $\begin{array}{l}\text { Sparse growth of saltgrass, alkali crust, } \\
\text { transition zone from lake bottom to } \\
\text { desert sand, surface moist to dry }\end{array}$ & 2,000 & 5.5 & 5.5 & 0.4 & 0.4 & 800 & 80 \\
\hline b & $\begin{array}{l}\text { Northern } \\
\text { transition zone } \\
\text { area }\end{array}$ & $\begin{array}{l}\text { Sparse growth of pickleweed and (or) } \\
\text { saltgrass or almost bare soil, generally } \\
\text { overlying older lacustrine deposits which } \\
\text { crop out to the north, locally spots of } \\
\text { alkali and puffy ground, moist beneath } \\
\text { surface crust }\end{array}$ & 1,800 & 5.5 & 7 & .4 & .2 & 720 & 36 \\
\hline VIa & $\begin{array}{l}\text { Areas bordering } \\
\text { China Lake and } \\
\text { extending to the } \\
\text { west }\end{array}$ & $\begin{array}{l}\text { Follows drainage lines, sparse growth of } \\
\text { saltgrass, alkali crust }\end{array}$ & 4,800 & 5.5 & 6 & 0.4 & 0.3 & 1,900 & 1,40 \\
\hline VIb & Northern swale & $\begin{array}{l}\text { Follows drainage lines, sparse growth of } \\
\text { pickleweed and (or) saltgrass, alkali } \\
\text { crust puffy in spots; lower end grades } \\
\text { into unit Illd }\end{array}$ & 190 & 5.5 & 6 & .4 & .3 & 80 & 6 \\
\hline VII a & $\begin{array}{l}\text { Dunes and inter- } \\
\text { dune playas west } \\
\text { of China Lake }\end{array}$ & $\begin{array}{l}\text { Small isolated playas (about } 10 \text { percent of } 1 \\
\text { area) surrounded by windblown sand and } \\
\text { dunes generally less than } 5 \text { feet above } \\
\text { playas; very sparse growth of saltgrass } \\
\text { on sand, playas generally bare and flat } \\
\text { with borders puffy; playas moist beneath } \\
\text { surface crust; sand areas dry from } 1.5 \text { to } \\
2 \text { feet below surface. Effective area of } \\
\text { evapotranspiration estimated at } 25 \text { percent } \\
\text { of total area }\end{array}$ & 13,900 & ${ }^{3} 4.5$ & 5 & 0.5 & 0.3 & 41,700 & ${ }^{4} 1,00$ \\
\hline VIIb & $\begin{array}{l}\text { Dunes and playas } \\
\text { north of dry } \\
\text { lake }\end{array}$ & $\begin{array}{l}\text { Small isolated playas surrounded by dunes } \\
\text { rising } 10 \text { to } 22 \text { feet above playas, very } \\
\text { sparse growth of saltgrass on dunes, playas } \\
\text { generally puffy. Effective area of } \\
\text { evapotranspiration estimated at } 20 \text { percent } \\
\text { of total area }\end{array}$ & $s$ & ${ }^{3} 5$ & 5 & .3 & .3 & 530 & 53 \\
\hline
\end{tabular}

The first six major units are after lee (1913); unit VIl and all subdivisions are by authors as shown in figure 13 .

The first six major units are dfter lee (1913); unit VIl and all subdivisions are by authors as shown in figure 13 .
ixcept in the lowest and most hrach sh are, of the molst linds, varlous specles of desert plants are common. However, all

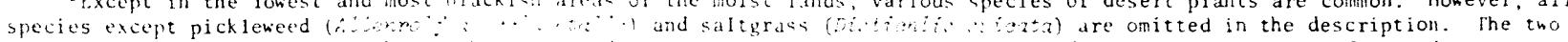

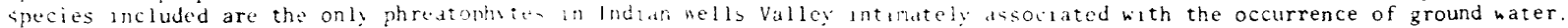

listimated.

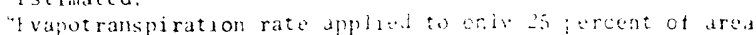

Ivapetranspiration rate applied to chl so forcent of area

Rounded to nearest 1 , 0041 a $r$ - fert 
The continuous gradient of the water-level contours drawn on water levels in deep wells tapping the main water body in the confined zone (fig. 6) indicates that ground-water outflow from Indian Wells Valley occurs through the well-defined channel to Salt Wells Valley in sec. 7, T. 26 S., R. 41 E. Geologic section $B-B^{\prime}$ (fig. 3) shows windblown sand in the old Lake China spillway through which ground water is now discharged. One can estimate the magnitude of this underflow according to the formula:

$$
Q=P I A
$$

where $Q=$ underflow,

$P=$ permeability of the water-bearing deposits,

$I=$ ground-water gradient,

and

$A=$ saturated cross-sectional area of the windblown sand in the old drainage channel.

Logs and water levels of test wells $26 / 41-7 G 1$ and $26 / 41-7 G 2$, drilled to bedrock in the outlet channel of Indian Wells Valley (fig. 6), indicate a head loss of 7.3 feet between the two wells which are 765 feet apart. The estimated saturated cross-sectional area $(A)$ based on a saturated thickness of 10 feet above bedrock in these wells and a width of channel of 200 feet is 2,000 square feet. The permeability $(P)$ of the windblown sand is estimated to be about 1,000 gallons per day per square foot; therefore,

$$
\begin{aligned}
& Q=1,000 \times \frac{7.3}{765} \times 2,000 \\
& Q=19,000 \mathrm{gpd} \\
& Q=20 \text { acre-feet per year }
\end{aligned}
$$

The outflow of 20 acre-feet per year is far less than the limits of error in the estimate of evapotranspiration and for all practical purposes may be disregarded in any quantitative estimate of total ground-water discharge or perennial yield. 
Pumpage

The early history of ground-water pumpage in Indian Wells Valley is sketchy. The reports of Lee (1913) and Thompson (1929) indicate that by 1919 many acres of land had been filed on with the U.S. Land office and that there had been considerable prospecting for ground water. However, little actual development of ground water had taken place by that time. Lee (1913) stated that in 1912 there were eight wells equipped with modern power pumps delivering water for irrigation use. He also stated that the best wells tested had yields of less than 60 miner's inches (540 gpm). Thompson (1929) stated that in 1919 the irrigated acreage did not exceed 800 acres. Based on these reports it does not seem likely that ground-water pumpage prior to 1919 ever exceeded 2,000-4,000 acre-feet per year and probably was considerably less.

For the period between 1920 and 1942 no data are available on which to base a firm estimate of the ground-water pumpage. However, Bailey (1946) inspected many of the ranches in Indian Wells Valley in 1921 and at that time only one seemed to be commercially productive. Reports of oldtime residents support this observation. Therefore, between 1919 and 1942 the ground-water pumpage probably averaged about 2,000 acre-feet per year. Bailey (1946) estimated 1943 pumpage for all uses as 2,800 acre-feet.

Beginning in February 1944, after location of the Naval Weapons Center at China Lake, the estimated pumpage for all uses has progressively and uniformly increased, as shown by table 10, from 2,300 acre-feet in 1942 to 12,400 acre-feet in 1966 .

TABLE 10.--Estimated pumpage, in acre-feet, for calendar years 1942-67

\begin{tabular}{l|c|c|c|c|c|c|c}
\hline Year & Pumpage & Year & Pumpage & Year & Pumpage & Year & Pumpage \\
\hline 1942 & 2,300 & 1949 & 5,600 & 1956 & 9,400 & 1963 & 11,000 \\
1943 & 2,800 & 1950 & 6,000 & 1957 & 9,400 & 1964 & 11,600 \\
1944 & 3,200 & 1951 & 6,500 & 1958 & 9,400 & 1965 & 11,600 \\
1945 & 3,600 & 1952 & 7,200 & 1959 & 10,000 & 1966 & 12,400 \\
1946 & 4,200 & 1953 & 8,200 & 1960 & 10,600 & 1967 & 12,300 \\
1947 & 4,600 & 1954 & 8,400 & 1961 & 10,300 & & \\
1948 & 5,000 & 1955 & 9,000 & 1962 & 11,000 & & \\
\hline
\end{tabular}


Total Discharge

The total yearly ground-water discharge from Indian Wells Valley is the sum of evapotranspiration, ground-water outflow, and net draft from pumping. The only year for which all estimates are available is 1953. Thus, the estimated total for 1953 is the evapotranspiration of 8,000 acre-feet, plus the underflow of 20 acre-feet, plus the pumpage of 8,200 acre-feet; or about 16,000 acre-feet.

The natural discharge under conditions of virtually no pumping is equal to: (1) The evapotranspiration plus the ground-water outflow. The estimated evapotranspiration in 1911 was 11,000 acre-feet and the outflow may have been somewhat more than 20 acre-feet. Accordingly, by this method the estimated total natural discharge was about 11,000 acre-feet a year; or (2) the underflow at midvalley, estimated to be at least 15,000 acre-feet a year. (See section on transmissibility of the alluvium.) Thus, there is an indicated difference between the two estimates of about 4,000 acre-feet a year.

\section{Ground-Water Recharge}

Under natural conditions all the water entering the ground-water bodies in Indian Wells Valley is derived from precipitation that falls within the drainage area of Indian Wells Valley and the smaller adjoining basins, Coso Basin and Rose Valley. Part of the precipitation is lost by evaporation from vegetative cover before it reaches the ground, part is lost by evaporation while running off into small streams in the canyons, and part goes into storage in the soil zone, where it is available for subsequent evapotranspiration through plants or soil. Another part is lost by evaporation from the open-water surfaces of the streams and of Little Lake in Rose Valley. The small part reaching the valley floor by direct precipitation is almost completely lost by evaporation and transpiration.

The residual part of the precipitation which percolates below the soil zone and enters the water-bearing deposits of the valley constitutes the recharge to the ground-water bodies. The largest increment of recharge for Indian Wells Valley is derived from the east slopes of the Sierra Nevada, west and southwest of Inyokern, where the heaviest precipitation within the area occurs. Second in importance are the steep fans and escarpment of the Sierra Nevada northwest of Inyokern, where the catchment area is smaller and the quantity of precipitation is less. A third increment, probably small, is derived from Rose Valley through a narrow channel at Little Lake. A very small quantity of recharge reaches the main water body from the Argus Range, but the quantity is small because of the small amount of precipitation in that area. Other very minor quantities are derived from Coso Basin and the El Paso Mountains. 
The available data on precipitation and runoff were too meager to stimate the ground-water recharge to the valley; but, under natural onditions--that is, prior to any pumpage--it would equal (1) the estimated vapotranspiration loss from the ground-water basin plus the small outflow to alt Wells valley or (2) the estimated underflow at midvalley. These uantities, discussed in the previous section, were estimated to be 11,000 nd 15,000 acre-feet.

\section{Perennial Yield}

The perennial yield of a ground-water basin may be defined as the rate at which ground water can be withdrawn year after year without depleting the ground-water storage to such an extent that withdrawal at this rate is no longer feasible because of increased pumping costs or deterioration of water quality.

The principal purpose of this investigation was to estimate the perennial yield of Indian Wells Valley. An estimate of perennial yield for a groundwater basin can be developed from the basic concept that, under natural conditions prior to pumping, the recharge equals the natural discharge. Hence, perennial yield is equal to the recharge or the natural discharge, minus any unrecoverable natural ground-water discharge, plus any salvable rejected recharge. For all practical purposes, in Indian Wells Valley there is no salvable rejected recharge. Therefore, the quantity of natural discharge salvaged each year should not deplete the ground-water storage to the point where this rate would cause chemical deterioration of the supply. Three methods for estimating the perennial yield in Indian Wells Valley are outlined, as follows:

1. Perennial yield is equal to recoverable evaporation and plant transpiration (evapotranspiration) plus recoverable ground water that may discharge by underflow out of Indian Wells Valley.

2. Perennial yield is equal to the total quantity of water moving through a cross-sectional area of the water body as defined along a waterlevel contour downgradient from any recharge, for a unit of time, $(Q=T I d)$, less unrecoverable water loss due to evapotranspiration and ground-water outflow.

3. Perennial yield is equal to the total precipitation that falls within the Indian Wells valley drainage area less unrecoverable water loss due to evapotranspiration and subsurface outflow. 
The data gathered during the investigation were sufficient to make independent estimates of perennial yield by use of methods 1 and 2 , above, but were insufficient to derive an estimate by use of method 3 .

With regard to the unrecoverable natural water loss indicated in all three methods outlined, this loss would need to be reduced to zero in order to intercept all recharge to the valley. However, a slight hydraulic gradient should be maintained toward the areas of poor-quality water in and near China Lake and east of Ridgecrest, and, as long as a gradient is maintained toward China Lake, there will be evapotranspiration loss in that area. Furthermore, under conditions of practical pumping regimen the gradient, and hence natural discharge, would be difficult to control. Accordingly, it is assumed that natural water loss by evapotranspiration and ground-water outflow could not be reduced to less than 1,000 acre-feet per year. The water-level contours (fig. 6) suggest that a small part of this loss would be supplied by recharge from Coso Basin and the Argus Range.

Thus, by use of the first method outlined above, the perennial yield is equal to the long-term average annual natural discharge, prior to any pumping, of about 11,000 acre-feet less the estimated minimum unrecoverable water loss of at least 1,000 acre-feet, or:

1. Perennial yield $=11,000-1,000=10,000$ acre-feet.

By use of this same method Lee (1913, p. 414) estimated the yield to be 11,000 acre-feet. However, Lee estimated the natural water loss to be 31,630 acre-feet and considered that about only one-third could be salvaged for use. This extremely high rate of discharge and low percentage of salvage does not seem justified in the light of more recent information.

By applying the second method outlined above, the perennial yield is nearly equal to the underflow at midvalley, prior to any pumping, of 15,000 acre-feet less the unrecoverable water loss of 1,000 acre-feet, or:

$$
\text { 2. Perennial yield }=15,000-1,000=14,000 \text { acre-feet. }
$$

Thus, perennial yield, estimated by two independent methods, differs by only 4,000 acre-feet. Because there is no reason to believe that one estimate is more accurate than the other and because they are both in reasonably close agreement, the perennial yield of Indian Wells valley is considered to be the average of the two, or is estimated to be about 12,000 acre-feet. This quantity then is the amount of water available for annual pumpage. 
GROUND WATER

Ground-water pumpage in 1953 was 8,200 acre-feet or about two-thirds of the estimated perennial yield. However, total discharge in 1953 was estimated to be about 16,000 acre-feet (see section on total discharge), or about 4,000 acre-feet more than the estimated perennial yield. This total.discharge in excess of the perennial yield is decreasing and will probably continue to decrease as pumpage intercepts more and more of the recharge that normally would be discharged by natural processes. This concept is borne out by the estimated reduction in natural discharge of about 3,000 acre-feet by 1953 . In order to reduce the natural discharge more effectively and to withdraw water with least risk of southwestward movement of saline water from the China Lake area, any new supply wells probably should be drilled in the area northwest of Intermediate where the water-level contours show that ground water is moving without interruption from the area of principal recharge to the area of natural discharge in and around China Lake.

\section{Disposal of Pumped Water}

Most of the ground water pumped in Indian Wells Valley is consumed in the valley. Of the total pumpage a small part is exported to another drainage area, a large part is disposed of as sewage effluent, and a small part is excess irrigation water.

Water pumped by the American Potash and Chemical Co. and the Westend Chemical Co., which totaled about 1,000 acre-feet in 1953, is exported out of Indian Wells valley for use at Trona and Westend.

Upon completion of the Ridgecrest sewage treatment plant, about 30-50 percent of the water pumped for public supply for Inyokern and Ridgecrest, which totaled about 500 acre-feet in 1953, will be run through sewage treatment plants and disposed of by evaporation from sewage ponds. Probably some of this effluent may reach the ground-water body, but the quantity is small.

Much of the pumpage for weapons center supply is discharged as sewage effluent mostly into several large ponds in sec. $14, \mathrm{~T} .26 \mathrm{~S} ., \mathrm{R} .40 \mathrm{E}$. Any effluent from the weapons center that does not evaporate from the ponds recharges the shallow water body south of China Lake. The shallow water body in this area is highly saline and is not adversely affected by the chemical quality of the effluent. Some of the effluent from the center is also used for the irrigation of a golf course in the vicinity of the treatment plant.

A small part of the ground-water pumpage for domestic use, which was only about 40 acre-feet in 1953, is discharged into septic tanks. Undoubtedly some of the septic-tank discharge returns to the main water body, but probably a major part is consumed by evapotranspiration of trees and other vegetation that are customarily planted in the vicinity of septic tanks for the express purpose of utilizing this discharge. 
A small part of the ground water pumped for agricultural irrigation probably returns to the main water body. However, as stated in the section on pumpage, the estimated withdrawal for irrigation is based on the estimated consumptive use of the crops grown, and, therefore, it is more nearly an estimate of net draft for irrigation rather than an estimate of pumpage for irrigation. Nevertheless, a part of the pumpage in excess of the estimated net draft, which was about 2,000 acre-feet in 1953, probably returns to the main water body.

Whether the estimated yield of 12,000 acre-feet could be pumped perennially would depend on what was done with the water. If it all were exported out of the drainage area, there would be no problem of concentration of salt in the soil or in the ground water; but, if it were consumed locally, roughly 7,000 tons of salt would be added yearly to the valley, based on an average concentration of dissolved solids in the water of $450 \mathrm{ppm}$. If it were consumed at land surface, all the salt would concentrate in the soil at places of consumptive use. Because rainfall is not sufficient to flush the salt into the ground-water body, the soil would be rendered poor or useless in the areas of the consumptive use in a short time. On the other hand, if enough excess irrigation water were applied to flush the salt downward, it would increase the salt concentration in the ground-water body. If most of the water were not used for agricultural purposes and if the excess were discharged into the playa area, as is the case with the weapons center effluent, the increase in tonnage of salt in the playa area would be of little concern except that it might be of ultimate economic interest.

\section{Ground-Water Storage Capacity}

Ground-water storage capacity may be defined as the reservoir space contained in a given volume of deposits. To be usable the ground water in storage must be able to drain by gravity during periods of pumping or other discharge; that is, the deposits must be capable of being dewatered. Furthermore, the deposits must be capable of being resaturated, if sufficient recharge is available. Because the discharge from ground water in 1953 was supplied in part from storage and because pumpage in future years may exceed the perennial yield, the ground-water storage capacity of Indian Wells Valley is critical with regard to the future supply. Thus, ground water in storage may be considered as a reserve to be utilized in conjunction with perennial yield should an emergency need arise for a supply greater than the perennial yield. 
Storage Units and Depth Zones

For Indian Wells Valley the ground-water storage capacity has been computed for two principal contiguous areas or units. These storage units were selected on the basis of the good water-yielding character of the deposits, good quality of water, average depth to water of about 160 feet for the west area and about 100 feet for the east area, and availability for utilization. The extent of the two units, which cover about 100 square miles, is shown in figure 14.

Storage unit I is limited on the west and south by the contact of the fan deposits and younger alluvium, as indicated on the geologic map (fig. 2), on the east by an irregular north-south line about one tier of sections east of T. $25 \mathrm{~S} .$, R. $38 \mathrm{E}$., and two tiers east of T. $26 \mathrm{~S} ., \mathrm{R} .38 \mathrm{E}$, , and on the north by the Inyo County line. The area is about 36 square miles or 23,000 acres. The depth to water is about 100 feet on the east and about 220 feet on the west.

Storage unit II includes an area extending from the east limit of unit I to an arbitrary line chosen with a view to avoiding the possible encroachment of poor-quality water from the east if the storage capacity in this area is utilized. For the south boundary the contact of younger alluvium and fan deposit has been used and the north boundary is the Inyo County line. The area is about 64 square miles or 41,000 acres. Storage unit II has been subdivided into two parts--one in T. $25 \mathrm{~S} ., \mathrm{R} .39 \mathrm{E}$., having an area of 16,000 acres, and the other in Tps. 26 and $27 \mathrm{~S}$, having an area of 25,000 acres. The average depth to water ranges from about 30 feet for the north part to about 150 feet for the south part.

The storage of the fan deposits has not been considered, as insufficient data are available concerning the depth to water and the character of these deposits. Ground-water storage capacity in the entire area of evapotranspiration (fig. 12) and in the area of older lacustrine deposits north and east of Ridgecrest have been omitted from all storage computations, as the water in these areas is generally of poor quality and the deposits are poorly permeable. Similarly, storage in the area east of Ridgecrest has also been omitted, as heavy pumping in this area has already produced some deterioration in quality.

Ground-water storage capacity in the two storage units has been estimated for the upper 100 feet of saturated material; that is, the quantity of ground water in storage to a depth of 100 feet below the 1954 water level. For those parts of the storage units within the weapons center boundaries a water level 100 feet lower than the 1954 level probably would be within practical pumping limits. 


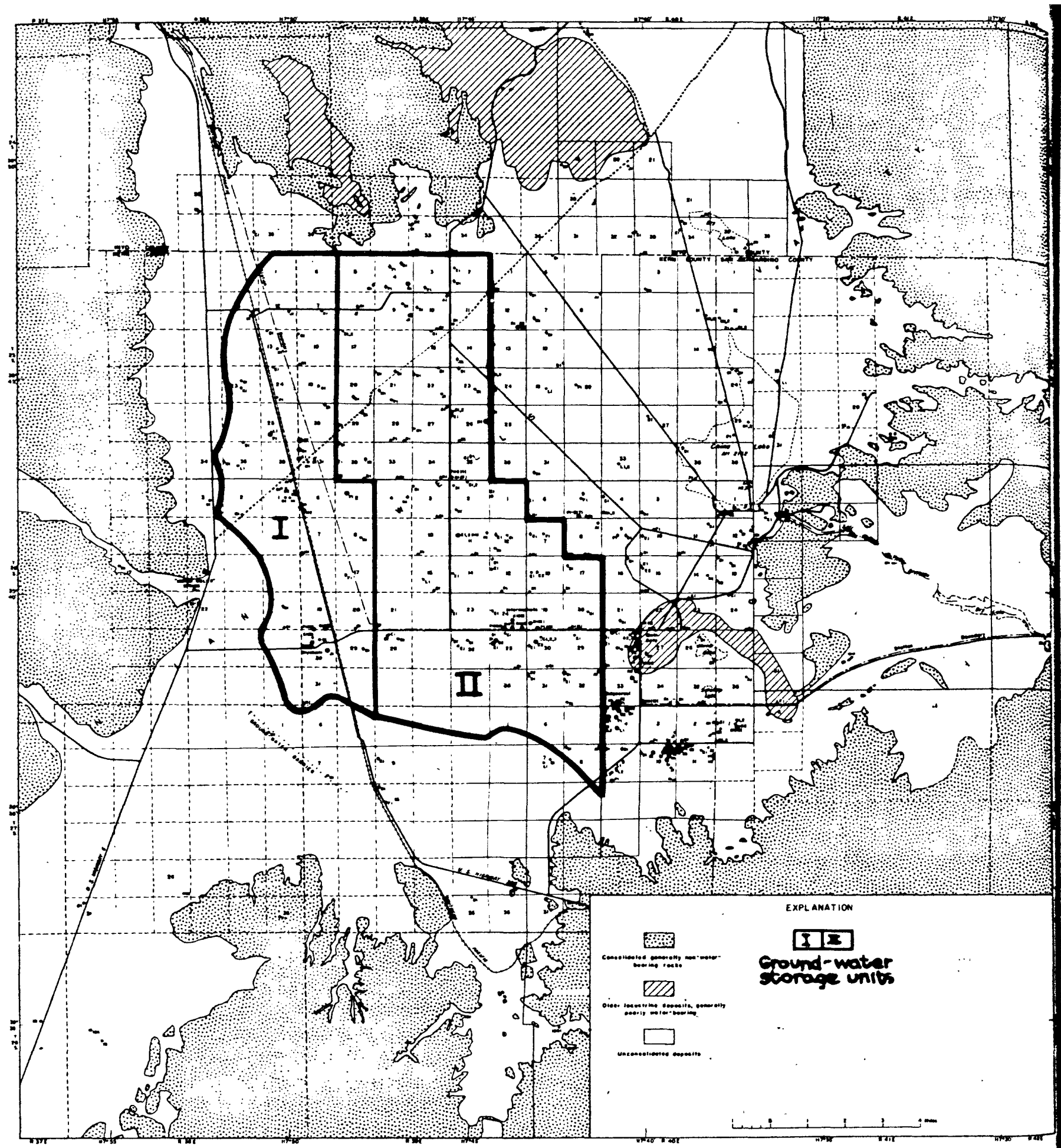

FIGURE 14.--Ground-water storage units. 
Specific-Yield Values

The specific yield of a given deposit or rock may be defined as the ratio f the volume of water the deposit will yield by gravity during dewatering to the total volume of the deposit. This value may be determined by laboratory tests of cores and samples, by pumping tests, or by assigning values of specific yield to materials described in well logs.

The pumping tests in Indian Wells Valley did not provide reasonable specific-yield values, and it was beyond the scope of the investigation to nake laboratory tests to determine specific-yield values. Accordingly, in Indian Wells Valley the materials described in well logs were grouped into five general classes having similar geologic properties (table 11). The specific-yield values assigned to these classes are based on results of several intensive field investigations in various parts of California. The most intensive of these was made by Eckis (1934) in the south-coastal basin of the Los Angeles area. Another intensive study was made in the Mokelumne darea in the northern part of the San Joaquin Valley by Piper, Gale, Thomas, and Robinson (1939). From these two sources, together with data from less detailed studies, specific-yield values have been selected which most closely represent the types of materials comprising the younger alluvium of Indian Wells valley, as shown in table 11. These values are considered to be conservative.

The specific-yield values shown in table 11 were assigned to the material described in drillers' logs from the water table to 100 feet below. The average of these values for storage unit $I$ is 12.4 percent, for the northern part of storage unit II in T. $25 \mathrm{~S}$., it is 13.1 percent, and for the southern part of storage unit II in Tps. 26 and $27 \mathrm{~S}$., it is 9.1 percent. The weighted average specific yield for both units is slightly more than 11 percent (table 12).

Another estimate of specific yield was computed as follows:

$$
\text { Specific yield }=\frac{(\text { Recharge })-(\text { pumpage }+ \text { evapotranspiration })}{\text { (Volume of materials dewatered) }}
$$

Based on data for the period 1946-53 the specific yield of the deposits dewatered is estimated as approximately 10 percent. However, owing to the lack of pumpage records prior to 1951 and owing to incomplete water-level records in 1946, which when compared to those in 1953 show the volume of materials dewatered, this estimate of specific yield is not used in any quantitative analysis in this report. Nevertheless, the estimate agrees closely with that shown in table 12 . 
TABLE 11.--Specific-yield values assigned to materials comprising the younger alluvizon

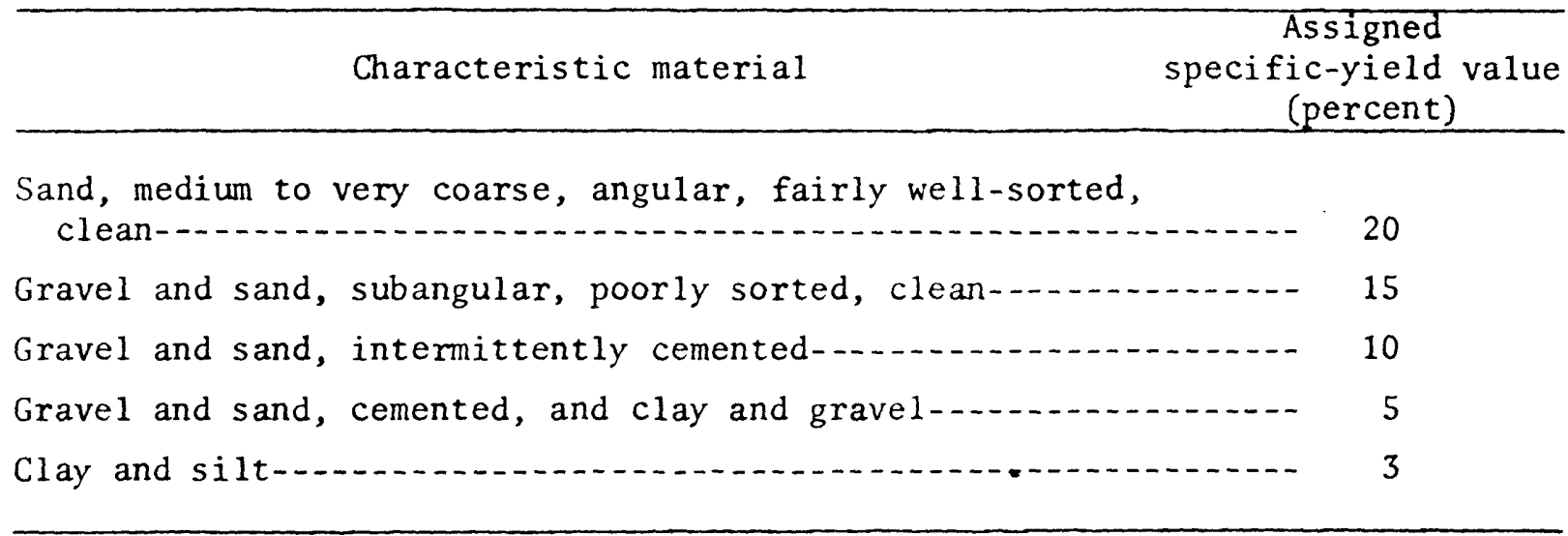

TABLE 12.--Estimated ground-water storage capacity of Indian Wells Valley

\begin{tabular}{|c|c|c|c|c|c|c|}
\hline Storage unit & $\begin{array}{c}\text { Total } \\
\text { area } \\
\text { (acres) }\end{array}$ & $\begin{array}{c}\text { Thi ckness } \\
\text { (feet) }\end{array}$ & $\begin{array}{c}\text { Total } \\
\text { volume } \\
(\text { acre-ft })\end{array}$ & $\begin{array}{c}\text { Average } \\
\text { specific } \\
\text { yield } \\
\text { (percent) }\end{array}$ & $\begin{array}{c}\text { Total } \\
\text { storage } \\
\text { capacity } \\
\text { (acre-ft) }\end{array}$ & $\begin{array}{l}\text { Percent } \\
\text { of } \\
\text { total } \\
\text { storage } \\
\end{array}$ \\
\hline Storage unit I & 23,000 & 100 & $2,300,000$ & 12.4 & 280,000 & 39 \\
\hline \multicolumn{7}{|l|}{ Storage unit II } \\
\hline Part in T. $25 \mathrm{~S}$. & 16,000 & 100 & $1,600,000$ & 13.1 & 210,000 & 29 \\
\hline $\begin{array}{l}\text { Part in Tps. } 26 \\
\text { and } 27 \mathrm{~S} .\end{array}$ & 25,000 & 100 & $2,500,000$ & 9.1 & 230,000 & 32 \\
\hline Subtotal & 41,000 & 100 & $4,100,000$ & 210.7 & 440,000 & 61 \\
\hline Total & 64,000 & 100 & $6,400,000$ & 211.2 & 720,000 & 100 \\
\hline
\end{tabular}

IStorage estimated to a depth of 100 feet below the water level of March 1954.

${ }^{2}$ Weighted average. 
Estimated Ground-Water Storage Capacity

The estimated ground-water storage capacity of storage units I and II was computed as the product of the area, in acres, the saturated thickness of $100 \mathrm{feet}$, and the average specific-yield value for the depth zone in each unit. The estimates so derived are shown in table 12. This table shows that the estimated total ground-water storage capacity is approximately 720,000 acre-feet for both storage units. Of this amount approximately 280,000 acre-feet is in storage unit I and 440,000 acre-feet is in storage unit II.

Utilization of all this storage would, however, be impossible with the existing distribution of pumping plants. For any contemplated future use additional wells judiciously spaced within the storage units would be necessary.

\section{Relation of Storage to Perennial Yield}

Under natural conditions prior to ground-water development, a dynamic balance is established between recharge and natural discharge. Over long periods of time the change in ground-water storage is virtually zero, and recharge and discharge are equal. Ground-water pumpage upsets this balance and in a closed basin, such as Indian Wells Valley, if pumpage should exceed recharge, ground water would be taken from storage, water levels would decline, and natural discharge eventually would cease. If pumpage continued to increase, water levels would continue to decline until it would become impractical to pump water at this rate because of decreased well yields, because of high pumping costs, or because of deterioration of water quality.

If ground-water pumpage is equal to or less than the perennial yield, the natural discharge plus pumpage, at first, will exceed perennial yield and ground water will be withdrawn from storage. However, if pumpage is held approximately constant and does not exceed the perennial yield, a new dynamic balance eventually will be established and pumpage plus a reduced rate of natural discharge will equal recharge.

In Indian Wells Valley from 1912 to 1953 the pumpage, which never has exceeded the estimated perennial yield, has caused natural discharge to decrease from about 11,000 to 8,000 acre-feet per year and has caused appreciable depletion of storage in the vicinity of Intermediate and Ridgecrest, as indicated by a decline of water levels in these areas. As indicated above, this is to be expected because the total discharge (evapotranspiration plus pumpage) exceeded perennial yield--for 1953 it was about 16,000 acre-feet or about 4,000 acre-feet more than the estimated perennial yield. However, unless annual pumpage should exceed the estimated perennial yield of 12,000 acre-feet, the quantity of water in storage and the rate of natural discharge will decline until the recharge and total discharge are again in dynamic balance. 
Even though annual pumpage through 1953 has not exceeded the perennial yield of the valley, the concentration of pumpage in the vicinity of Intermediate and Ridgecrest eventually may cause a local deterioration of water quality. The most effective use of ground water in Indian Wells Valley would be achieved by a more even area $i$ distribution of pumpage in ground-water storage units I and II (fig. 14). It then would be possible to pump about 12,000 acre-feet of water per year with a minimum depletion of ground-water storage and with little or no migration of water of poor quality toward the areas of withdrawal.

\section{REFERENCES CITED}

Babbitt, H. E., and Doland, J. J., 1949, Water supply engineering: New York, McGraw Hill Book Co., Inc., 637 p.

Bailey, Paul, 1946, Report on the water supply of Indian Wells Valley, Kern County, California, to the Lands Division, Department of Justice:

U.S. v. 529,533 acres of land in the counties of Inyo, Kern, San Bernardino, etc., et al., no. 3472-H civil.

Baker, C. L., 1912, Physiography and structure of the western El Paso Range and the southern Sierra Nevada: California Univ., Dept. Geol. Sci. Bull., v. 7, p. 117-142.

Blackwelder, Eliot, 1931a, Pleistocene glaciation in the Sierra Nevada and Basin Ranges: Geol. Soc. America Bull., v. 42, p. 865-922.

1931b, The lowering of playas by deflation: Am. Jour. Sci. 5th ser., v. 21, p. $140-144$.

1933, Lake Manley, an extinct lake of Death Valley: Geol. Rev., v. 23, p. $464-471$.

1941, Lakes of two ages in Searles Basin, California: Geol. Soc. America Bull., v. 52 .

1948, The Great Basin, the geological background: Utah Univ. Bull., v. 38, no. 20 , pt. 1, 16 p.

Blaney, H. F., 1951, Consumptive use of water: An. Soc. Civil Engineers, v. 77 , separate 91 .

1952, Determining evapotranspiration by phreatophytes from

climatological data: Am. Geophys. Union Trans., v. 33, p. 61-65.

Blaney, H. F., and Criddle, W. D., 1949, Consumptive use of water in the irrigated areas of Upper Colorado River Basin: U.S. Dept. Agriculture, Soil Conserv. Service, Div. Irrig. and Water Conserv.

California State Water Resources Board, 1951, Water resources of California: Bul1. 1, $648 \mathrm{p}$. 
Dibblee, T. W., Jr., 1952, Geology of the Saltdale quadrangle, California: California Div. Mines Bul1. 160.

1967, Areal geology of the western Mojave Desert, California: U.S. Geol. Survey Prof. Paper 522, $153 \mathrm{p}$.

Eckis, Rollin, 1934, South coastal basin investigation, geology and groundwater storage capacity of valley fill: California Div. Water Resources Bul1. 45, $273 \mathrm{p}$.

Fenneman, N. M., 1931, Physiography of Western United States: New York, McGraw-Hill Book Co., Inc., 534 p.

Gilluly, James, Waters, A. C., and Woodford, A. 0., 1951, Principles of geology: San Francisco, W. H. Freeman and Co., 631 p.

Goudy, R. F., 1936, Solving boron problems in Los Angeles water supply: Western Construction News, v. 11, p. 295.

Hi11, M. L., and Dibblee, T. W., Jr., 1953, San Andreas, Garlock, and Big Pine faults, California: Geol. Soc. America Bull., v. 64, p. 443-458.

Hubbs, C. L., and Miller, R. R., 1948, The Great Basin, the zoological evidence: Utah Univ. Bull., v. 38, no. 20, pt. 2, p. 17-190.

Hulin, C. D., 1925, Geology and ore deposits of the Randsburg quadrangle, California: California Mining Bur. Bul1. 95.

1934, Geologic features of the dry placers of the northern Mojave Desert: California Div. Mines Rept. 30, p. 417-426.

Knopf, Adolph, 1918, A geologic reconnaissance of the Inyo Range and the eastern slope of the southern Sierra Nevada, California: U.S. Geol. Survey Prof. Paper 110, $130 \mathrm{p}$.

Lee, C. H., 1913, Ground-water resources of Indian We1ls Valley, California: California State Conserv. Comm. rept., p. 403-429.

1942, Transpiration and total evaporation, in Physics of the earth, v. 9, Hydrology: New York, Dover Publishing, Inc., p. 259-330.

Louderback, G. D., 1924, Period of scarp production in the Great Basin: California Univ., Dept. Geol. Sci. Bull., v. 15.

McKee, J. E., and Wolf, H. W., eds., 1963, water quality criteria: California Water Quality Control Board, Pub. no. 3-A, 548 p.

Meinzer, O. E., 1923a, The occurrence of ground water in the United States: U.S. Geo1. Survey Water-Supply Paper 489, 321 p.

1923b, Outline of ground-water hydrology with definitions: U.S. Geol. Survey Water-Supply paper 494, $71 \mathrm{p}$. 
Meinzer, 0. E., 1927, Plants as indicators to ground water: U.S. Geol. Survey Water-Supply Paper 577, $95 \mathrm{p}$.

Merriam, J. C., 1914, The occurrence of Tertiary mammalian remains in northeastern Nevada: California Univ., Dept. Geol. Sci. Bull., v. 8, p. 275-281.

Moyle, W. R., Jr., 1963, Data on water wells in Indian Wells Valley area, Inyo, Kern, and San Bernardino Counties, California: California Dept. Water Resources Bu11. 91-9, 243 p.

Piper, A. M., Gale, H. S., Thomas, H. E., and Robinson, T. W., 1939, Geology and ground-water hydrology of the Mokelumne area, California: U.S. Geol. Survey Water-Supply Paper $780,230 \mathrm{p}$.

Reed, R. D., 1933, Geology of California: London, Thomas Murphy and Co., $355 \mathrm{p}$.

Samse1, Howard, 1950, Geology of the southeast quarter of the Cross Mountain quadrangle: California Univ., Los Angeles, unpub. M.S. thesis.

Smith, Alfred, and Skarn, C. F., 1927, Maximum height of capillary rise starting with soil at capillary saturation: California Agr. Exp. Sta. Hilgardia, v. 2, p. 399-409.

Thompson, D. G., 1929, The Mohave Desert region, California: U.S. Geol. Survey Water-Supply Paper 578, 759 p.

Twenhofel, W. H., 1932, Treatise on sedimentation: Baltimore, Williams and Wilkins Co., 2d ed., 926 p.

U.S. Public Health Service, 1946, Drinking water standards: Rept., v. 61, no. 11, p. 12 .

Wenzel, L. K., 1942, Methods for determining permeability of water-bearing materials: U.S. Geol. Survey Water-Supply Paper 887, 192 p.

Whistler, J. T., 1923, Report on Indian Wells Valley and Fremont Valley, California: California Div. Water Rights mimeo. rept., 83 p.

Wilcox, L. V., 1948, The quality of water for irrigation use: U.S. Dept. Agriculture Tech. Bul1. 962, 40 p.

Wilcox, L. V., Hatcher, J. T., and Blair, G. Y., 1951, Quality of water in Indian Wells Valley, California: U.S. Dept. Agriculture, Salinity Lab. research rept. 54 .

Young, A. A., and Blaney, H. F., 1942, Use of water by native vegetation: California Div. Water Resources Bull. 50. 